PNE-RB-70

\title{
PROJECT RIO BLANCO \\ FINAL REPORT \\ REENTRY DRILLING AND TESTING \\ OF RB-E-01 WELL
}

October 1975

\begin{abstract}
This report was prepared as an account of work sponsored by the United States Government. Neither the United States nor the United States Energy Research and Development Administration, nor any of their employees, nor any of their contractors, subcontractors, or their employees, makes any warranty, express or implied, or assumes any legal liability or responsibility for the accuracy, completeness or usefulness of any information, apparatus, product or process disclosed, or represents that its use would not infringe privately owned rights.
\end{abstract}

\section{CER Geonuclear Corporation Continental Oil Company}




\section{DISCLAIMER}

This report was prepared as an account of work sponsored by an agency of the United States Government. Neither the United States Government nor any agency Thereof, nor any of their employees, makes any warranty, express or implied, or assumes any legal liability or responsibility for the accuracy, completeness, or usefulness of any information, apparatus, product, or process disclosed, or represents that its use would not infringe privately owned rights. Reference herein to any specific commercial product, process, or service by trade name, trademark, manufacturer, or otherwise does not necessarily constitute or imply its endorsement, recommendation, or favoring by the United States Government or any agency thereof. The views and opinions of authors expressed herein do not necessarily state or reflect those of the United States Government or any agency thereof. 


\section{DISCLAIMER}

Portions of this document may be illegible in electronic image products. Images are produced from the best available original document. 


\section{PREFACE}

This volume is a report on the postdetonation reentry and production phases of Project Rio Blanco. The predetonation and detonation phases were reported on in the Project Rio Blanco Detonation Phase Final Report. (1)

For planning details on the Project, refer to the Project Rio Blanco Definition Plan ${ }^{(2)}$ in three volumes. Volume I contains a general description of the entire project.

Volume II details the tasks that were needed for the operational scope of work related to the detonation such as site construction, power installation and distribution, drilling of the emplacement well, stemming plans, operational safety, seismic effects documentation, and ground water protection program, as well as several add-on programs. Volume III incorporates all planning of ti:e activities that were related to the chimney reentry and reservoir testing and evaluation. For the most part, these plans will not be repeated here.

The three nuclear explosives for Project Rio Blanco were detonated at 1000:00. $12 \pm 0.01$ second, Mountain Daylight Time, or 1600:00.12£0.01 second, Greenwich Mean Time, on May 17, 1973. The three explosions occurred within the Fort Union and Mesaverde formations at depths of 5,838.5 feet, 6,229.7 feet, and 6,689.5 feet. The three explosions occurred nearly simultaneously as planned and were completely contained. Available data indicate that the yields of the three explosives totalled approximately $90 \mathrm{kt}$. The elevation of the ground at the emplacement well, RB-E-01, is $6,629.9$ feet above mean sea level. RB-E-01 is located 1,080.50 feet south of the north line and 1, 188.49 feet east of the west line in Section 14, Township 3 South, Range 98 West of 6th P. M., Rio Blanco County, Colorado, which corresponds to geodetic coordinates of $108^{\circ} 21^{\prime} 59^{\prime \prime}$ west longitude and $39^{\circ} 47^{\prime} 35^{\prime \prime}$ north latitude. 
-

$\bullet$

-ii - 
TABLE OF CONTENTS

Page

PREFACE

1

INT RODUCTION

․ $\ldots, \ldots$

2.1

GENERA LIZED SITE ACTIVITIES

2. 2

2. 3

2.4

2. 5

2.6

2. 7

Site Preparation. .

ACTIVITIES

Power Installation and Distribution

Communications

Industrial Safety...

... ... . .

Rollup

Other Support

REENTRY DRILLING PROGRAM - RB-E-01

3.1

Reentry Drilling

Schedule as Achieved ...

4 PRODUCTION TESTING

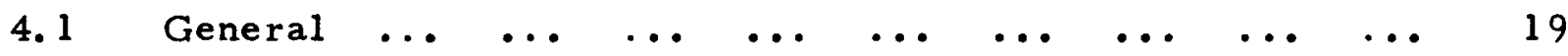

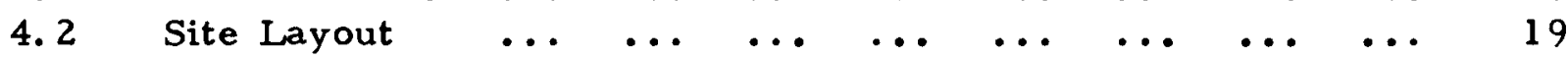

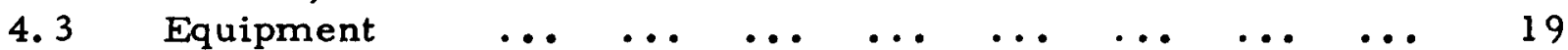

4. 4 Test Schedule - Flow Rate and Duration f.. . . . . . 24

4. 5 Automation and Alarm System $\ldots \ldots \ldots \ldots 33$

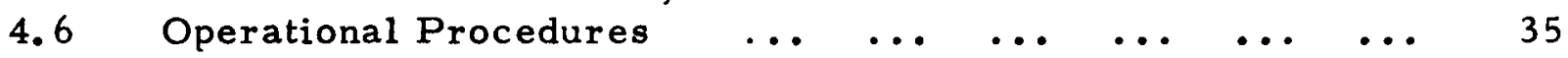

4. 7 Gas Supply/Water Disposal Well $\ldots \ldots \ldots \ldots$

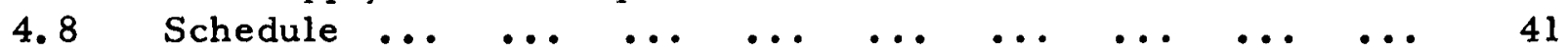

5 RADIOLOGICAL SAFETY AND EFFLUENT DOCUMENTATION 43

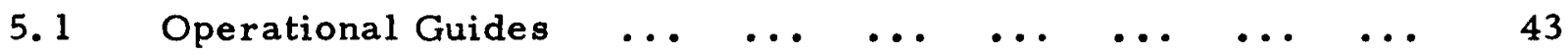

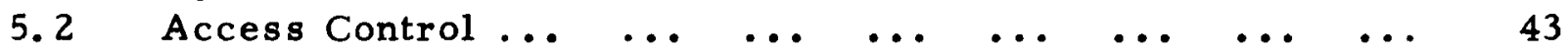

5.3 Personnel Dosimetry and Bioassay $\ldots \ldots \ldots \ldots 44$

5. 4 Effluent Documentation During the Delay Period ... ... 44

5. 5 Effluent Documentation During Initial Reentry Drilling ... 45

5.6 Effluent Documentation During Subsequent Reentry Drilling 45

5. 7 Effluent Documentation During Production Testing ... ... 46

5.8 Summary of Effluent Data $\ldots$...

6 RADIOLOGICAL MONITORING IN THE ENVIRONMENT _.. 49

APPENDIX A Daily Drilling Reports, RB-E-01 $\ldots \ldots \ldots$... 51 
$\underline{\text { Page }}$

APPENDIX B Daily Drilling Reports, Fawn Creek Government \# 1 Well, Reentry and Recompletion, June 18 September 17, 1973, and Remedial Work, November 23 - December 5, $1974 \ldots \ldots$.... ... ...

APPENDIX C Permit for Subsurface Disposal Findings of Fact, Public Hearing on Water Disposal Application ...

APPENDIX D-1 Bottom Hole Pressure and Temperature Data with Corresponding Flow Rates, First Production Test

A PPENDIX D-2 Bottom Hole Pressure and Temperature Data, First Pressure Build-Up Period $\ldots$... $\ldots$...

APPENDIX D-3 Bottom Hole Pressure and Temperature Data, with Corresponding Flow Rates, Second Production

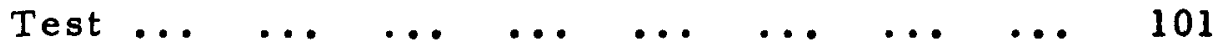

A PPENDIX D-4 Bottom Hole Pressure and Temperature Data, Second Pressure Build-Up Period ... $\quad \ldots \quad \ldots \quad 109$

APPENDIX E Summaries from Relevant Radiological Monitoring Program Reports... $\quad \ldots . \quad \ldots \quad$..

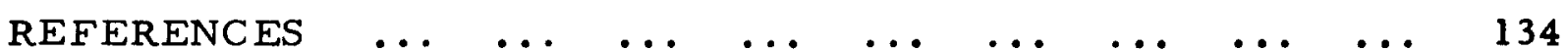




\section{ILLUSTRATIONS}

$\underline{\text { Figure }}$

Page

1. Effluent and Disposal Points, Project Rio Blanco Production Testing $\ldots \ldots \ldots \ldots \ldots \ldots \ldots \ldots$

2. Layout of Trailers During Reentry Drilling and Production

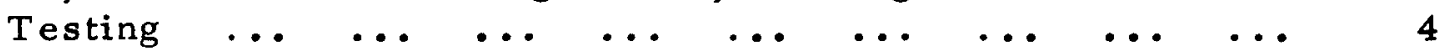

3. Grand Junction Office and Warehouse Complex _.. . . $\quad 5$

4. Distribution of Telephone and Radio Circuits in the EW Area 7

5. Diagram of Microwave Telephone and Radio Waves _.. 9

6. Schematic of Drill Rig Layout for Reentry Drilling ... ... 14

7. Schematic of Completed Reentry Well $\quad \ldots \quad \ldots \ldots \ldots$

8. Reentry Drilling Schedule as Accomplished $\ldots \ldots \ldots$... $\quad \ldots \quad 17$

9. Layout of Facilities During Production Testing _.. . . 20

10. Flow Configuration During Production Tests ... ... ... 21

11. Schematic of RB-E-01 Wellhead and Lubricator for Production Testing $\ldots \ldots \ldots \ldots \ldots \ldots$

12. Time History of Operating Temperatures, First Production

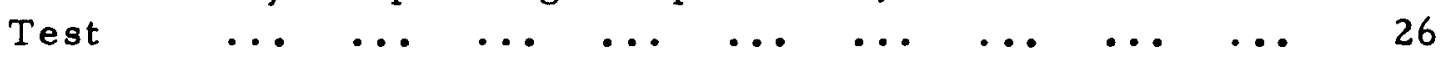

13. Time History of Bottom Hole Pressure and Temperature, First Production Test

14. Time History of Operating Temperature, Second Production Test $\ldots \ldots \ldots \ldots \ldots \ldots \ldots$

15. Bottom Hole Pressure Buildup, RB-E-01, After First

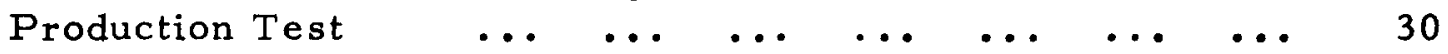

16. Time History of Bottom Hole Pressure, Temperature and Flow

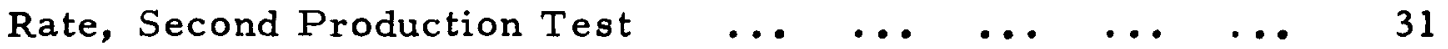

17. Bottom Hole Pressure Buildup, RB-E-01, After Second Production Test... ... ... ... ... ... ... ... 


\section{ILLUSTRATIONS (CONT.)}

Figure

$\underline{\text { Page }}$

18. Time History of Water Production (kilopounds) per Unit Volume (MMSCF) of Total Gas Flow, with Correlative Bottom Hole Pressure... $\ldots$...

19. Layout of the Alarm and Control Panel ... $\ldots \ldots \ldots$

20. As-Built Downhole Completion Detail, Fawn Creek Govern-

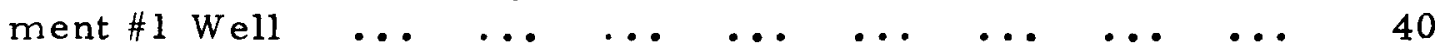

21. Production Testing and Pressure Buildup Monitoring Schedule as Accomplished $\ldots \ldots \ldots \ldots \ldots$

22. Production Test Gas Sampling System ... ... ... ... 


\section{INTRODUCTION}

Project Rio Blanco was designed as the first phase of a three-phase experimental program to demonstrate the potential of commercial development of a natural-gas field by nuclear stimulation techniques in the Piceance Basin in Rio Blanco County, Colorado. Because the gas is tightly held within the surrounding rock, this field has not been developed by conventional stimulation methods. At the time of this writing, however, massive hydraulic fracturing experiments are underway to investigate further this technology for development of gas fields. One of these experiments ${ }^{(3)}$ is being conducted at a site within one mile of the nuclear experiment.

The first phase of the nuclear experiment consisted of the simultaneous detonation of three nuclear explosives at different depths within the Fort Union and Mesaverde formations. The detonations were designed to stimulate a 1,350-foot vertical section of the Fort Union and Mesaverde formations. After a five-month waiting period, a reentry well was completed into the gasfilled chimney associated with the upper explosive, and the reservoir testing and evaluation began. The field activities related to this reentry drilling and chimney pressure drawdown are the subject of this report. Figure 1 shows the principal locations of project activities. 


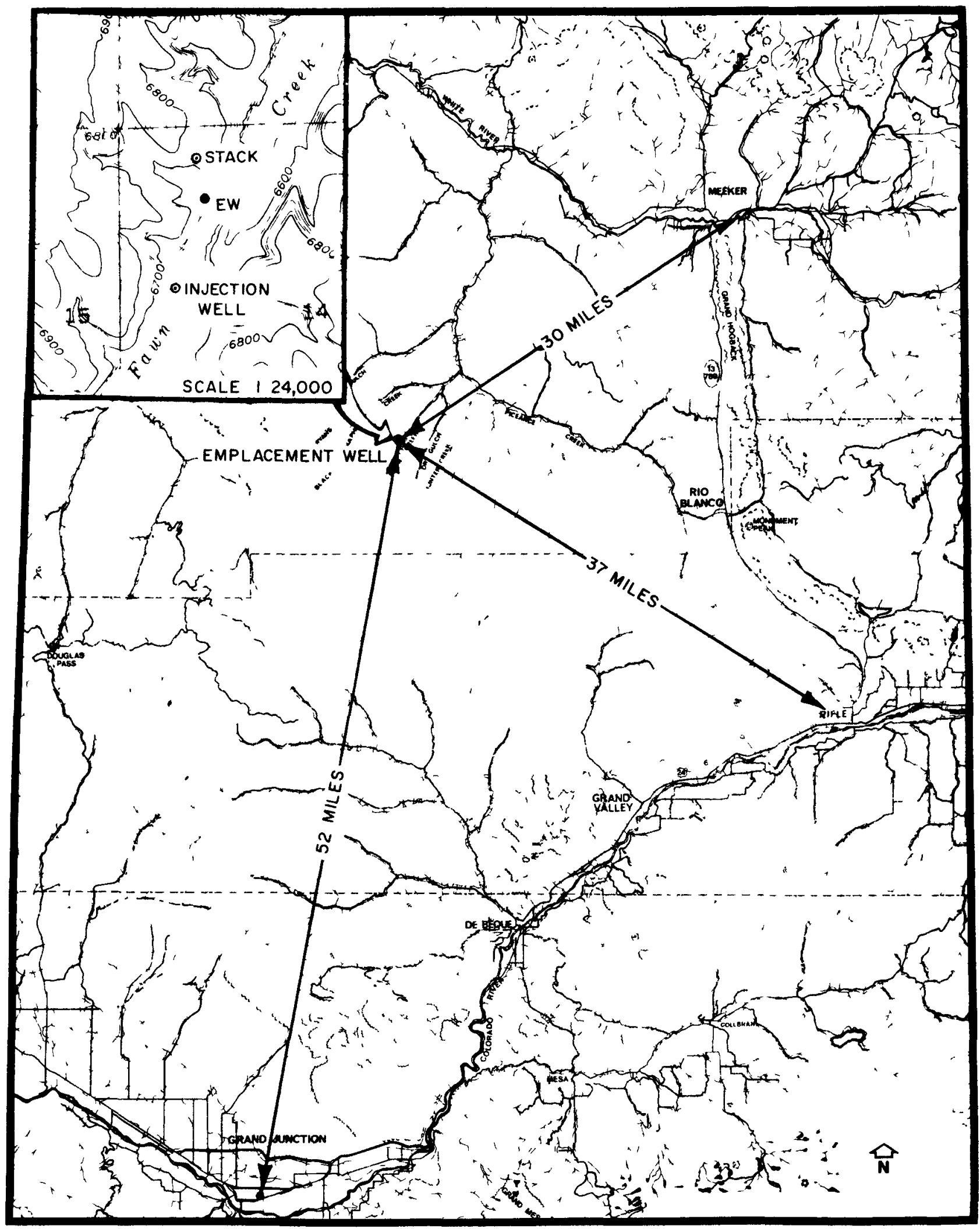

Figure 1. Effluent release and disposal points, Project Rio Blanco production testing. 


\section{GENERALIZED SITE ACTIVITIES}

Prior to the start of reentry drilling activities, the Fawn Creek access road and emplacement well (EW) were regraded and prepared for the subsequent activities.

An office trailer was provided for the use of the Atomic Energy Commission (AEC), Lawrence Livermore Laboratories (LLL), CER Geonuclear Corporation (CER), Continental Oil Company (Conoco), and other project participants. Two mobile homes were provided, one for LLL and representatives of the drilling tool companies and the other for CER/Conoco personnel. The drilling contractor provided a self-contained camping trailer for its superintendent during the drilling phase. The radiological protection trailers used by the Radiological Support Contractor (RSC) were supplied by the AEC as Government-furnished-equipment. CER's own effluent documentation system, the TRY-KRY, was also installed in a trailer. Figure 2 shows the placement of all trailers on-site during the reentry drilling and production testing of the RB-E-01 well.

The flare stack was located in the clearing to the northwest and above the EW, and the previously cleared cableway became the process piping route. The areas which included the flare stack, process piping, storage and condensate tanks, separator, and wellhead equipment were fenced with three strand barbed wire to prevent livestock from entering the area and to control personnel access.

The Grand Junction Control Point (GJCP) at the CER/Conoco office and warehouse complex (Figure 3) in Grand Junction was maintained through the conclusion of the production testing of the RB-E-Ol well.

\section{2 POWER INSTALLATION AND DISTRIBUTION}

As equipment and trailers were delivered, the electric distribution cables and connections were reestablished to the electrical distribution panels. Sufficient spare safety switches were initially installed to provide the following anticipated electrical demand. 


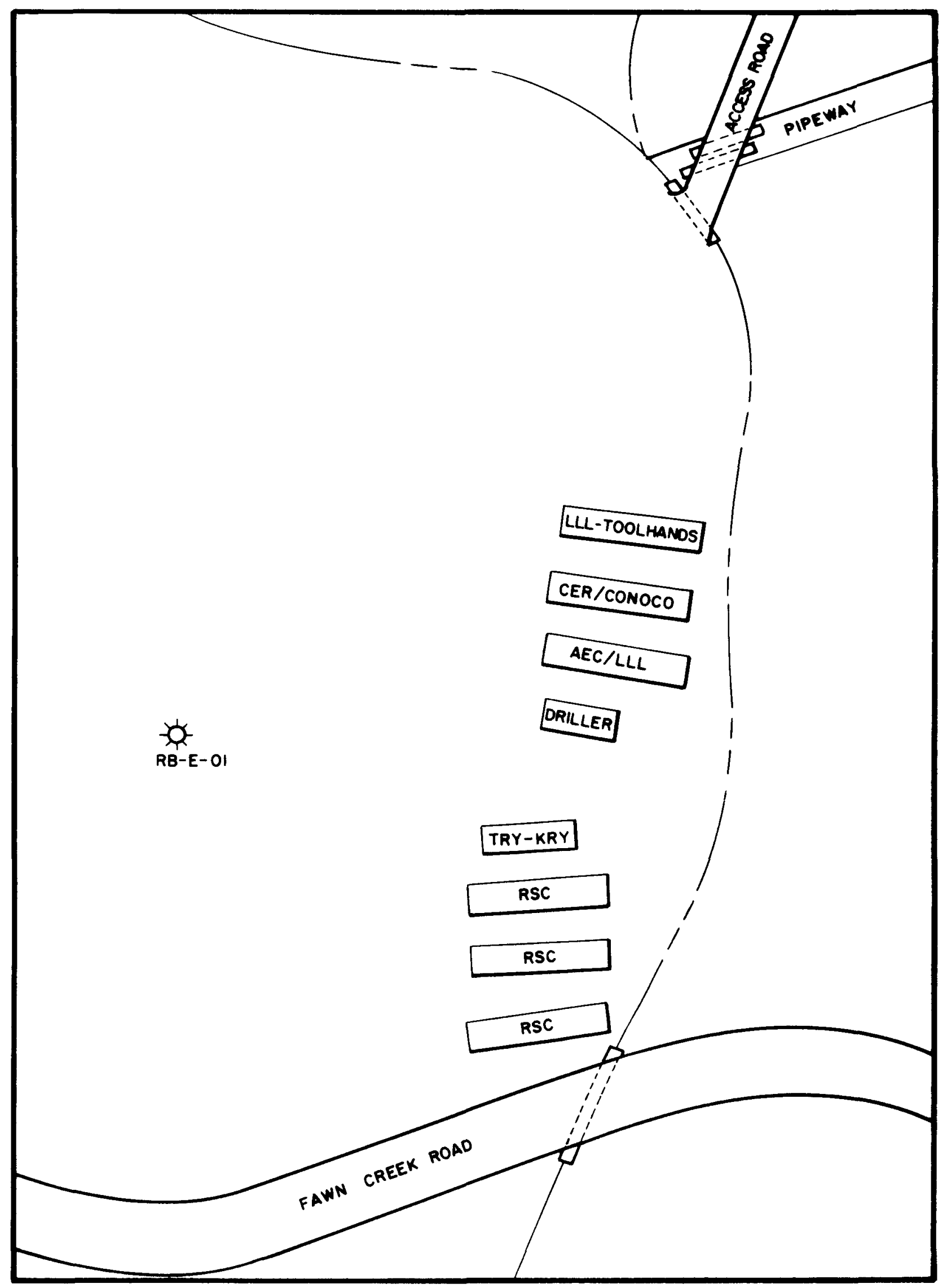

Figure 2. Layout of trailers during reentry drilling and production testing. 


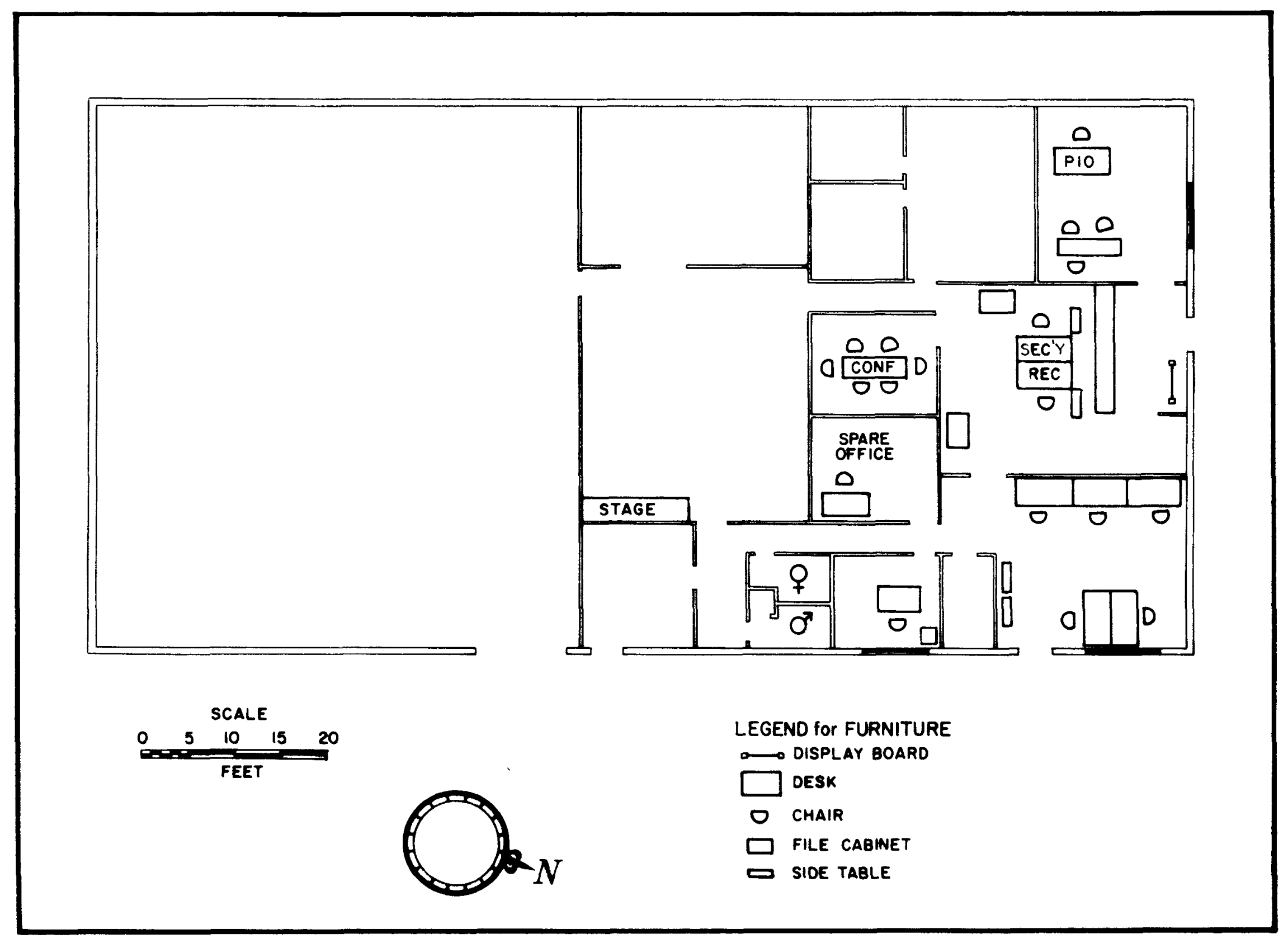

Figure 3. Grand Junction office and warehouse complex. 


\section{Drilling (KW)}

Radiological Safety Contractor (RSC)

AEC

Tool Hands

Tool Pusher

CER

Area Lighting

TRY - KRY

Instrumentation

Water Injection Pump

Communications Equipment

Heat Tape

Total

Use Load Factor

Power Required

$\begin{array}{rr}40 & 40 \\ 10 & 10 \\ 5 & -- \\ 5 & 5 \\ 10 & 10 \\ 10 & 10 \\ 30 & 30 \\ 1 & 5 \\ -- & 50 \\ 5 & 5 \\ -- & 40 \\ 116 & - \\ & 185 \\ 0.8 & \\ 93 & 0.8\end{array}$

An additional $50-\mathrm{kVA}, 3$-phase transformer was provided to supply power to the 50-hor sepower water injection pump. This increased the electric power provided to the $\mathrm{EW}$ to $150 \mathrm{kw}$ (nominal). However, during the first production test, it was determined that the temperature of the flowing gas was excessive; and the decision was made to add fin-fan coolers upstream of the separator before further testing. The $13 \mathrm{kw}$ required made it necessary to change from a 50-kw transformer to a 75-kw transformer.

Electric service from a commercial source was available at the GJCP and was distributed as shown in the project definition plan. (2)

\section{$2.3 \quad$ COMMUNICATIONS}

The principal telephone and radio communication facilities for the project were located in Grand Junction where the CER microwave telephone system interconnects with the Mountain Bell telephone system.

Microwave communication equipment was utilized for both the telephone and the VHF duplex radio net. Microwave telephone relay stations were located at Lands End and Monument Peak with terminal equipment in the CER communications shed approximately $1 / 2$ mile west of the EW. A VHF base station was also located in the communications shed. Existing signal cable laid during the detonation phase was utilized to provide telephone and VHF radio service to the EW area, as shown in Figure 4. A Xerox telecopier was available at both the GJCP and the EW for transmission of printed or written material.

The CER telephone system at the EW site operates over a microwave link as a direct dialing extension of a Grand Junction telephone exchange of the Mountain Bell telephone system. Four telephone lines originate in a Grand Junction 


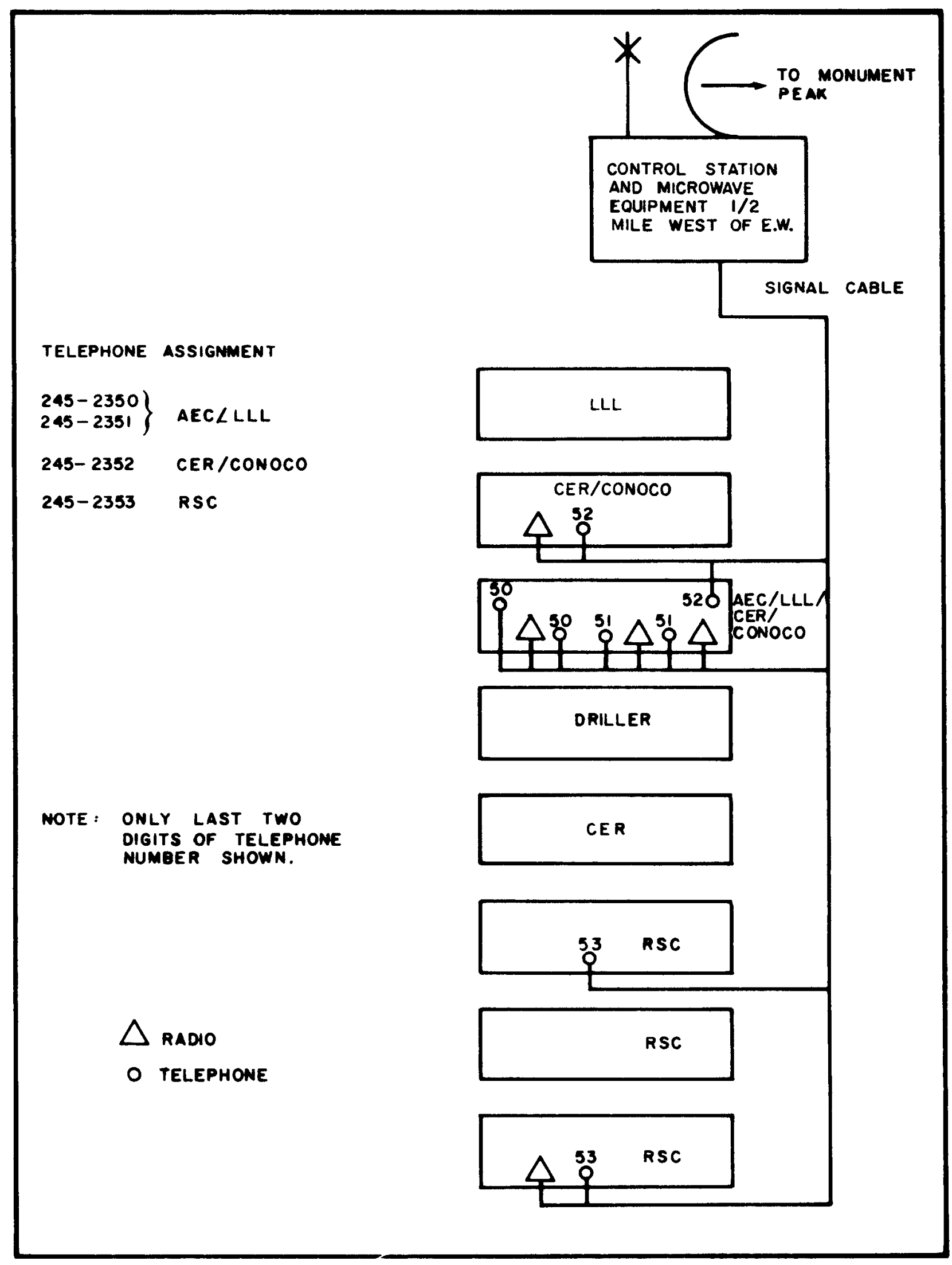

Figure 4. Distribution of telephone and radio circuits in the EW area. 
telephone exchange and terminate at the EW. Figure 5 diagrams the microwave telephone and radio system.

Individual telephone numbers were assigned to each of the four telephone lines from the Grand Junction telephone office. A telephone directory of telephone numbers and respective locations and organizations was published.

A radio relay station located at Monument Peak provided adequate radio communication between fixed stations at the EW and GJCP and among fixed stations and mobiles in the Piceance Creek Basin. Communication with mobiles outside the basin was limited by line-of-sight restrictions.

A limited number of mobile radios were furnished by CER for use by those project participants directly involved with field activities during the experiment and were used primarily for coordination of logistic requirements.

In the event of commercial power failure, the microwave telephone system and the VHF radio repeater and control station continue to operate on battery power for a minimum of 8 hours.

Frequencies for the CER VHF radio net are:

Repeater/fixed, mobile

Repeater/fixed, mobile
Transmit/Receive

Receive/Transmit
153. $350 \mathrm{MHz}$

$158.370 \mathrm{MHz}$

Transmit frequencies for the microwave system are as follows:

Grand Junction to Lands End

Lands End to Monument Peak

Monument Peak to EW

EW to Monument Peak

Monument Peak to Lands End

Lands End to Grand Junction
$956.700 \mathrm{MHz}$

$953.500 \mathrm{MHz}$

$956.900 \mathrm{MHz}$

953. $300 \mathrm{MHz}$

$957.100 \mathrm{MHz}$

$953.100 \mathrm{MHz}$

2. 4

INDUSTRIAL SAFETY

2. 4.1

General

CER operations and activities were conducted in accordance with the standards of the Occupational Safety and Health Act of 1970. All participating organizations were responsible for the health and safety of their own personnel and for conducting all activities in accordance with procedures that assure:

1. A safe and healthful environment for their employees.

2. Control and minimization of hazards to the public and to personnel of other participants. 


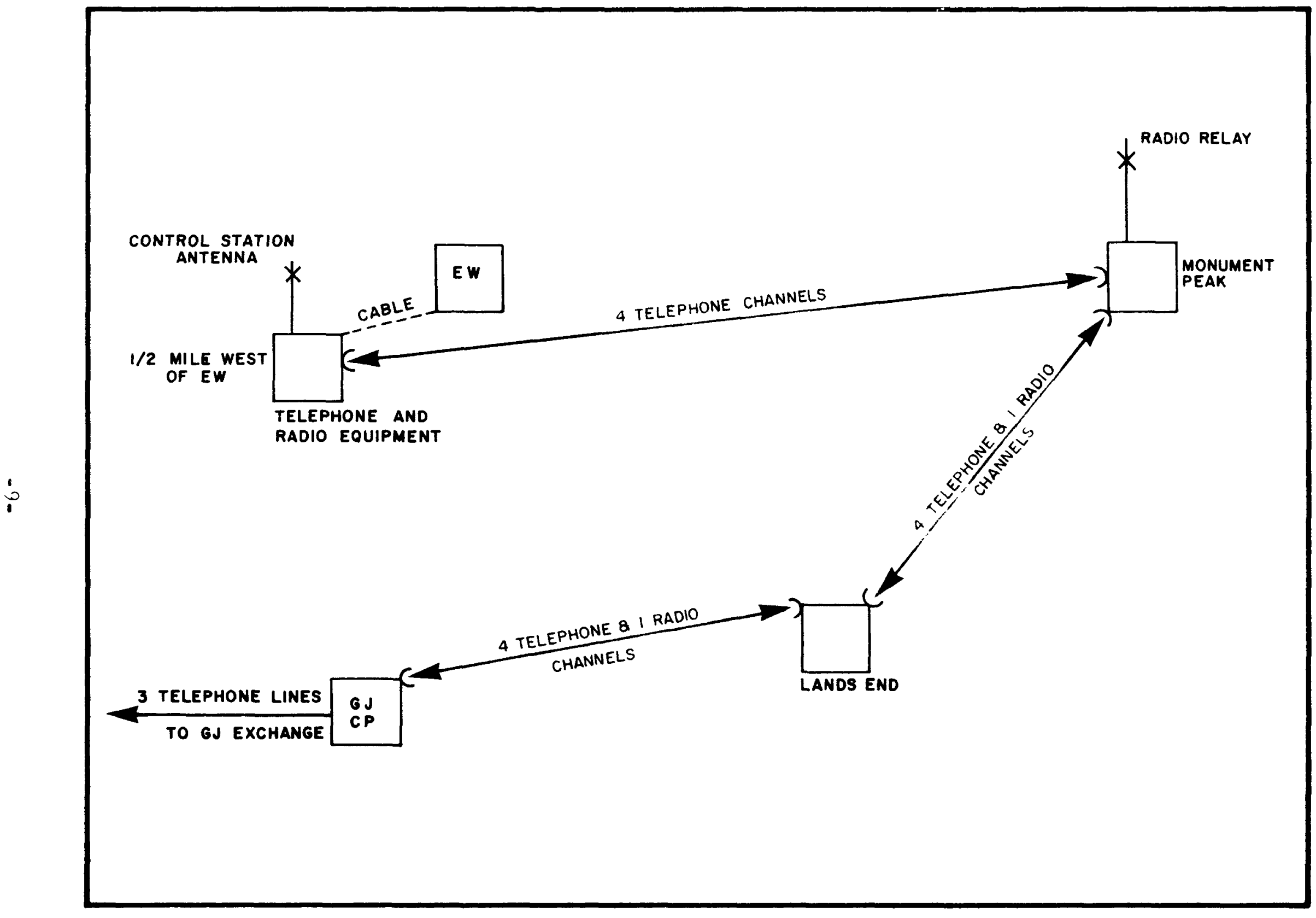

Figure 5. Diagram of microwave telephone and radio system. 
3. Minimization of the accidental damage or loss of company and privately owned equipment, materials, and property.

\section{4.2 General Safety}

Reentry of the stimulated gas zone involve general construction work, drilling, and installation of high-pressure piping and pressure vessels. The following safety standards were established as criteria for the performance of this work:

1. National

2. General Safety Requirements - Corps of Engineers

3. ASME - Boiler and Pressure Vessel Code

4. API - Recommended Standards and Procedures

5. AAODC - Tool Pushers Manual

\subsubsection{First Aid}

During the reentry drilling and first production testing, CER provided an experienced first aid man and a radio equipped ambulance on each work shift. The first aid men were off-duty personnel of the Grand Junction emergency rescue division of the fire department. The first aid man was stationed in the office trailer, provided by CER, which was equipped with suitable first aid supplies as recommended by a local physician. CER also provided each participating agency contacts with local medical facilities and physicians in the Grand Junction, Rifle, and Meeker areas for use in the event of accident or illness. The availability of an ambulance and a first aid man on-site was suspended after the first production test and not resumed during the second production test because of reduced manning level.

\section{5 GENERAL SUPPORT REQUIREMENTS}

Drinking water was furnished in cool cans at the EW. Janitorial service was provided at the EW on a minimal basis. Occasional secretarial and clerical services were also available. Office furniture was supplied at the GJCP as shown in Figure 3. Chemical toilets were provided at the EW. Waste and garbage cans were provided around the working areas at both the GJCP and EW. Disposal of refuse was handled by an approved local agency. Air conditioning was not generally furnished to trailers at the EW. Trailers furnished by CER were heated by propane fuel. The RSC and TRY-KRY trailers were air conditioned as required to assure stability of electronic equipment. Furnaces or heaters were of an approved vented type. An emergency fuel 
and lubricating oil supply for vehicles and equipment was furnished at the EW.

Dry chemical type fire extinguishers were located around the EW as were barrels filled with a mixture of water and antifreeze in the event of fire. No fires were experienced on the project.

CER/Conoco provided miscellaneous labor to support the project as well as transporting, shipping, receiving, and hauling various supplies and materials for the participants. Approximately 1,200 square feet of enclosed warehousing was utilized at the GJCP office. Limited enclosed storage was available at the EW area for spare parts and equipment. Sufficient open storage space was available at the GJCP and EW areas. Dust control, snow removal, and normal "good housekeeping" maintenance of the access road and EW area were performed on an as required basis.

2.6

ROLLUP

The rollup activities contemplated in the project definition plan (2) have not been accomplished as of the date of this report. Additional drilling and testing activities reported elsewhere or yet to be undertaken have resulted in indefinite postponement of this activity.

2. 7

OTHER SUPPORT

The GJCP was operated during normal business hours to support the project. Normal functions of administrative, secretarial and clerical work were performed. Warehousing, shipping, and receiving facilities were maintained. The GJCP served also, during this period, as a base for handling claims resulting from the detonation, as described in Reference 1, and for limited public information activities. 
-

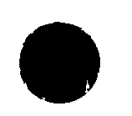

$-12-$ 


\section{REENTRY DRILLING PROGRAM - RB-E-01}

Upon conclusion of the principal activities associated with the detonation phase of the Rio Blanco experiment, CER/Conoco began preparation for reentry drilling and subsequent production testing of $R B-E-01$. The initial step was to relocate the $\mathrm{RSC}$ trailers to the emplacement well pad and to initiate routine radiological surveillance of the area during the 3 -month delay that was scheduled to allow the decay of short-lived radioactivity in the chimney, in particular, $13 l_{\mathrm{I}}$.

Pipe and assorted materials were delivered to the site and welding and assembly of the various pipe lines began. The flare stack and drip pans were shop fabricated and delivered to the site. As soon as the foundation and guy anchors were installed for the flare stack, it was erected. Tankage (water and condensate storage) was set in place and interconnecting piping was installed for the tankage, separator, and water disposal pump. Instrumentation was installed and associated signal cable routed to connect to the alarm and control panel.

While this preparatory work was in progress, the gas sampling program described in the project definition plan(2) was attempted with indifferent results. Attempts to remedy downhole blockage of the gas sampling tube were not successful. The effort was finally abandoned and the open downhole portion of the tube was plugged with epoxy as planned as a precautionary measure.

Difficulty was experienced in obtaining a drill rig that met the safety and operating criteria. Even after a suitable drill rig was located, a delay occurred while the drill rig completed another assignment before moving to the reentry well location. Once the drill rig availability was established, the drilling well control (DWC) unti, blowout preventer (BOP) equipm ent, explosive gas monitoring system, radiation detection equipment, and various other supplies were coordinated into the reentry schedule. (See Figure 6 for layout of reentry equipment. ) As the assembly and erection of the drill rig progressed, drip pans were installed at the wellhead cellar, DWC, shaker table, and drill pipe stands on the rig floor and decontamination pad areas. The natural gas pipe line from the Fawn Creek Government No. 1 Well was completed and the natural gas used as a purge system in the flow lines to prevent an explosive mixture from accumulating.

Prior to the start of drilling, tests of the BOP, DWC, flow lines, and safety monitoring systems were satisfactorily conducted. With the testing completed, reentry drilling betan on September 23, 1973.

\subsection{REENTRY DRILLING}

Reentry was through the 7 -in. emplacement casing using a downhole motor (Dyna Drill) and a 6-1/8-in. mill to drill out the cement plug inside the 7-in. 


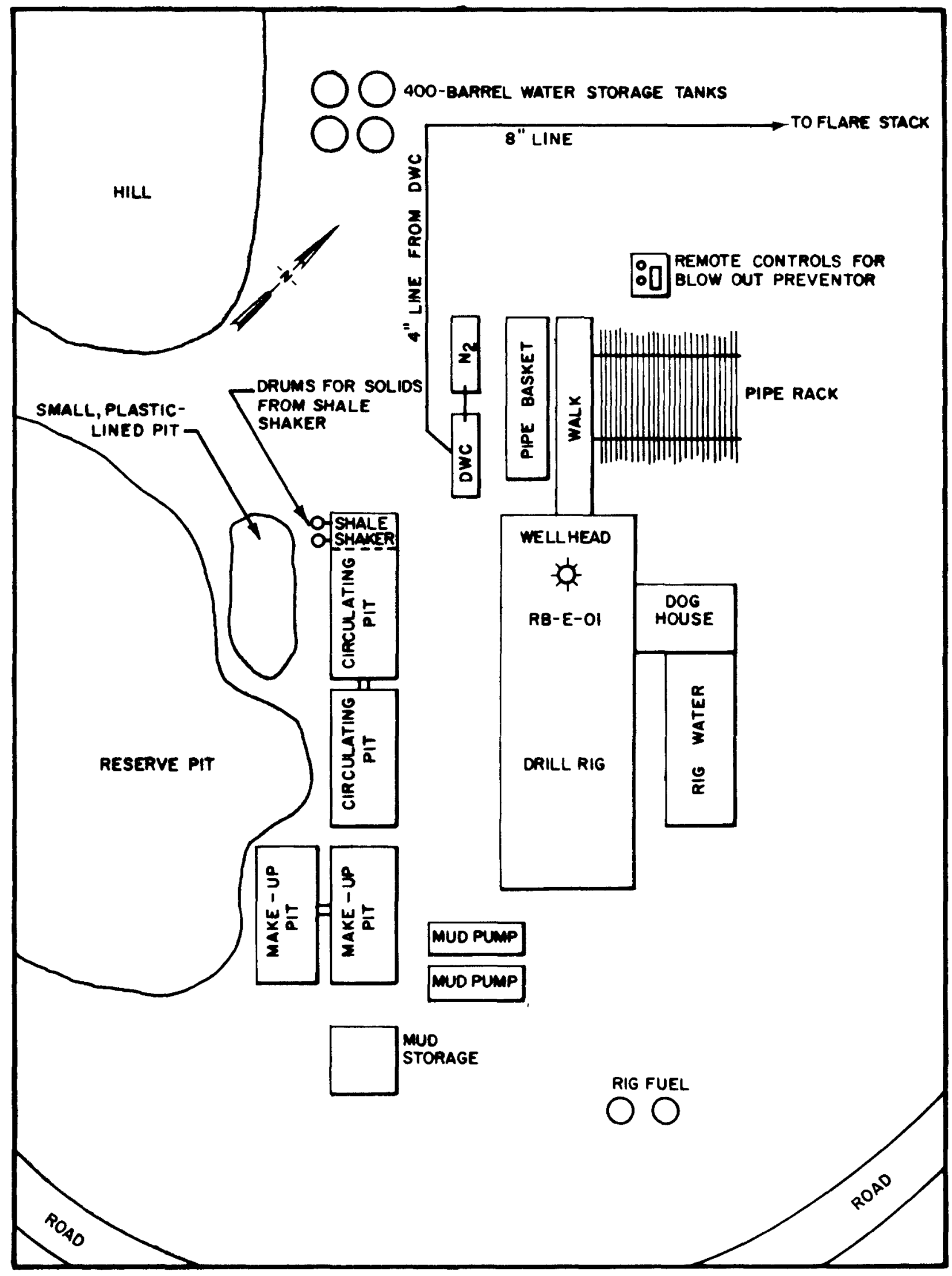

Figure 6. Schematic of drill rig layout for reentry drilling (not to scale). 
casing from approximately 2,797 ft KB (Kelly Bushing) to approximately $5,194 \mathrm{ft} \mathrm{KB}$. Below the cement plug, it was found that the gelled water used in stemming had failed to do the expected, i. e., lose its high viscosity and flow into the chimney. Hence, progress into the hole was made by circulating out the gel to $5,35 \mathrm{lft} \mathrm{KB}$. Below 5,35l $\mathrm{ft} \mathrm{KB}$, it was necessary to mill through crushed casing over the following intervals: $2 \mathrm{ft}$ at $5,351 \mathrm{ft}, 2 \mathrm{ft}$ at $5,452 \mathrm{ft}, 1 \mathrm{ft}$ at $5,484 \mathrm{ft}, 4 \mathrm{ft}$ at $5,494 \mathrm{ft}$ and $43 \mathrm{ft}$ at 5,506 ft, all depths KB. Only $5 \mathrm{ft}$ of hole was made below $5,349 \mathrm{ft} \mathrm{KB}$ with returns being formation plus metal. Apparently the hole was milled through the 10-3/4-in. casing at about $5,551 \mathrm{ft} \mathrm{KB}$.

Due to continuing difficulties, it was decided to abandon the well below $5,350 \mathrm{ft}$ $\mathrm{KB}$ and proceed with alternate reentry plan number one, described in Reference 2 as follows. A whipstock was set at $5,322 \mathrm{ft} K B$. A mill was used to drill out of the 7-in. and 10-3/4-in. casings. Drilling continued outside the casings to a total depth of $5,706 \mathrm{ft} \mathrm{KB}$ with no drilling mud returns at all below 5,633 ft KB. Gas pressure was encountered and recorded at the surface at $5,671 \mathrm{ft} \mathrm{KB}$. The well was then completed (Figure 7) and, after a 1-3/4-hour flow test through the DWC unit to ensure adequate communication with the chimney, the drill rig was released. The well was then ready for connection to the production and testing equipment. The daily drilling reports for reentry are presented in Appendix A.

\section{2 SCHEDULE AS ACHIEVED}

The schedule of the major elements of the Reentry Drilling Program, as achieved is shown in Figure 8. 


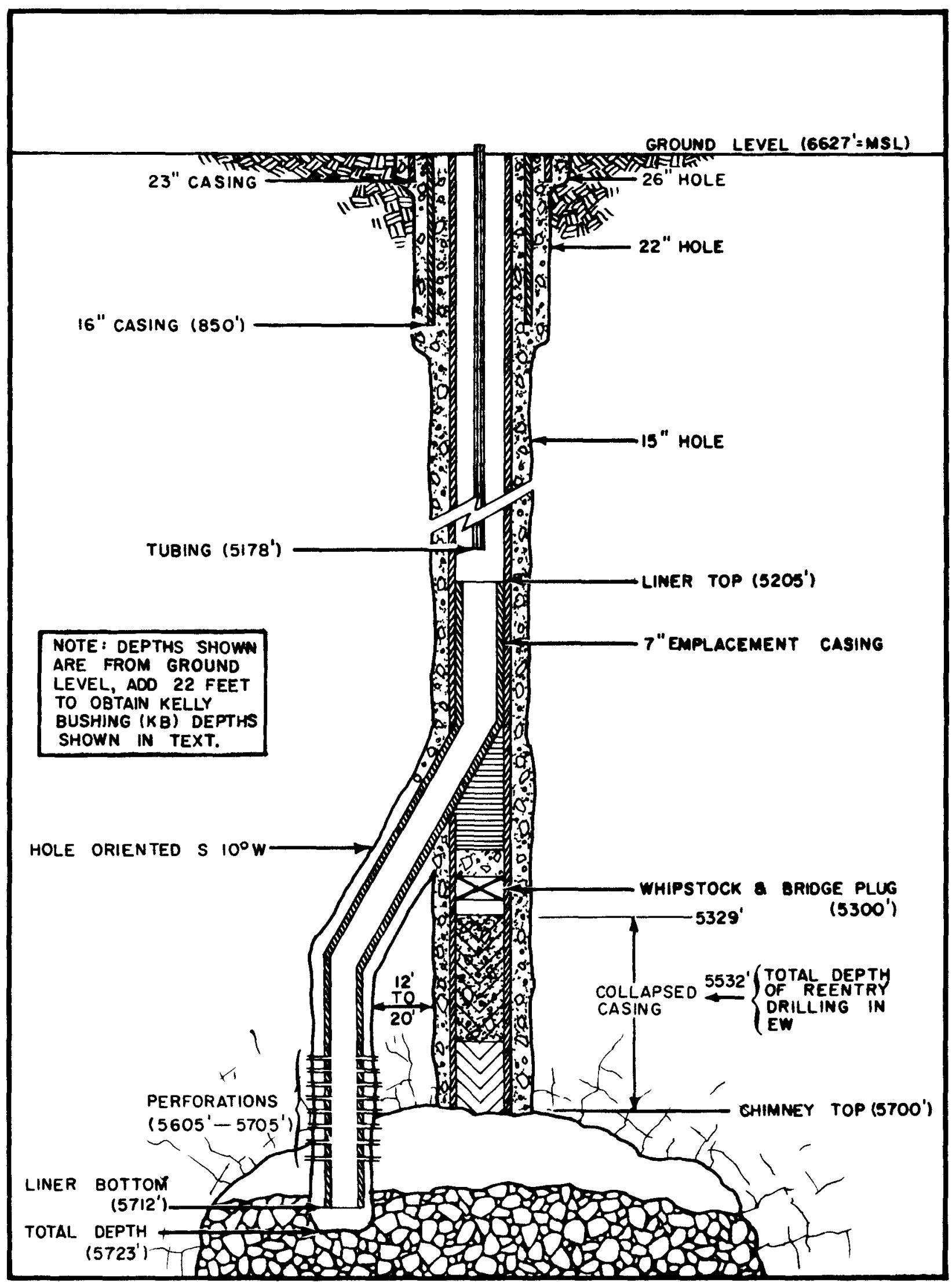

Figure 7. Schematic of completed reentry well. 


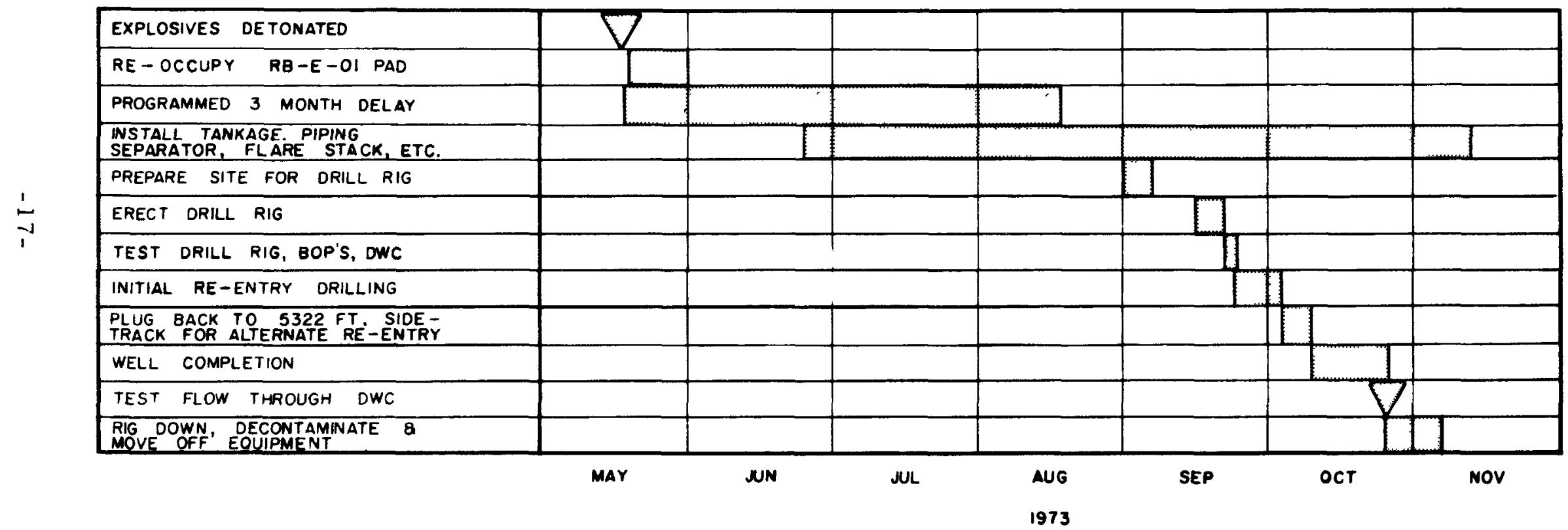

Figure 8. Reentry drilling schedule as accomplished. 
$-18-$ 


\section{PRODUCTION TESTING}

\section{1 GENERAL}

The objectives of the production testing program were:

1. A production period to measure the pressure drawdown occurring within the chimney in relationship to the quantity of gas produced in order to calculate chimney volume and effective fracture volume.

2. A long-term pressure buildup to determine the extent of fracturing and virgin reservoir characteristics.

3. Quantitative analysis of the produced gas to determine its physical components including radioactive species and to determine the degree of communication between chimneys.

4. Detailed analysis of results compared to predictions.

\section{2 SITE LAYOUT}

Figure 9 indicates the location of the components for the two production testing phases. Due to the problems encountered from the high temperature of the flowing gas, the first production test was shortened in order to make certain modifications, including installation of three fin-fan coolers ahead of the separator to drop the temperature of the flowing gas to an acceptable level. The flow configuration of the produced gas and the separator products is shown in Figure 10.

\section{3 EQUIPMENT}

Prior to and during the reentry drilling, installation of the production and testing equipment progressed. Water and condensate storage tanks, water disposal pump, separator, critical flow prover, gas sampling spool, and flare stack were installed. The piping connecting the various components was fabricated and installed. The instrument control piping was completed to provide control gas to various instruments as well as natural gas to the pilot lights on the flare stack and heaters in the water storage tanks and separator. The control panel with its alarm and monitoring functions was installed and signal cable terminated to its appropriate device and tested. Tubing was connected to the gas sampling spool and run to the gas conditioning skid which supplied dry gas to the RSC and TRY-KRY trailers for sampling. With rig, $B O P$, and DWC removed, it was necessary to reroute and install additional flow piping for the production testing of the well. As the piping was assembled into the various systems and neared completion, each line was pressure tested to ensure against leaks. 


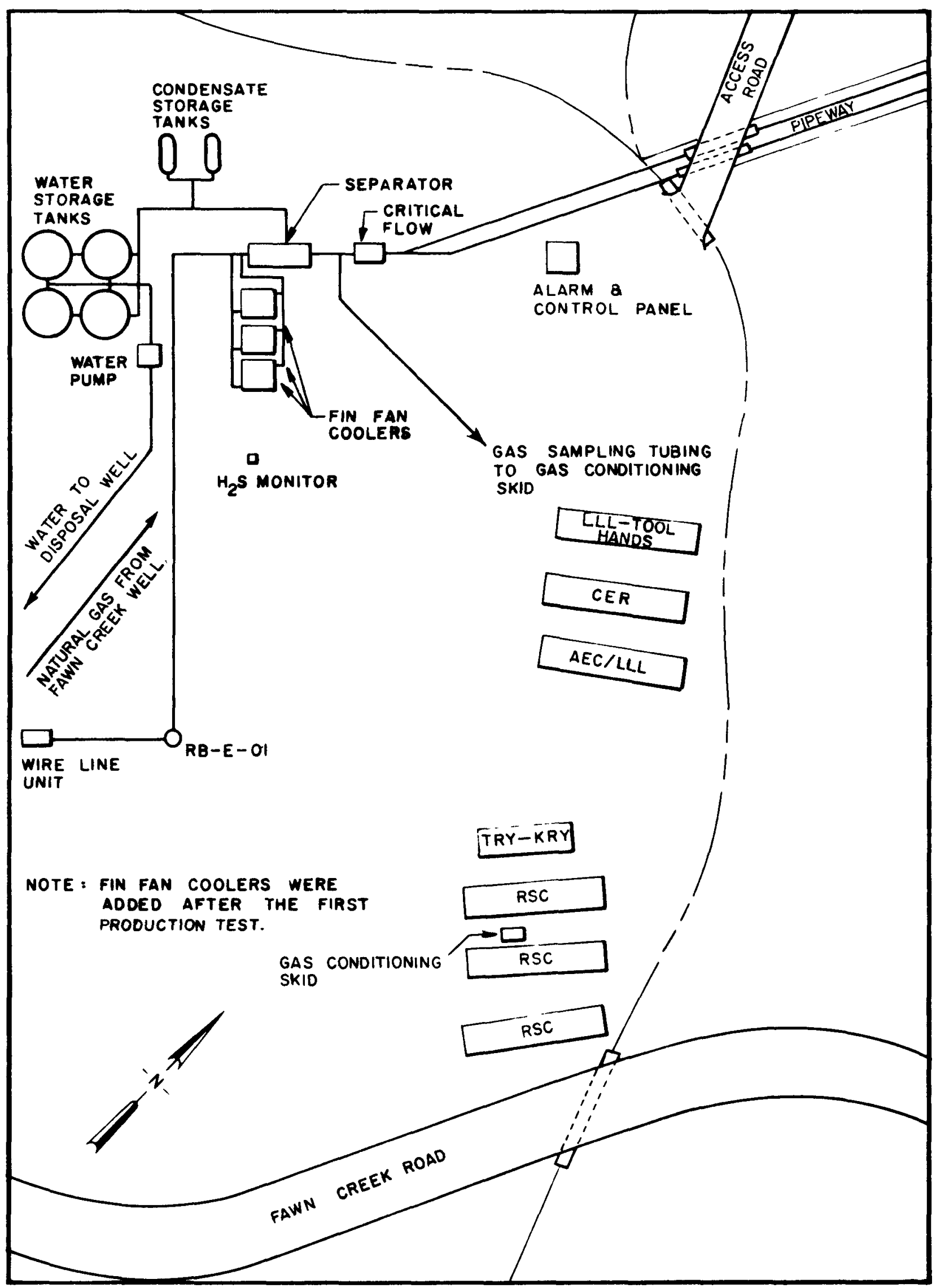

Figure 9. Layout of facilities during production testing. 


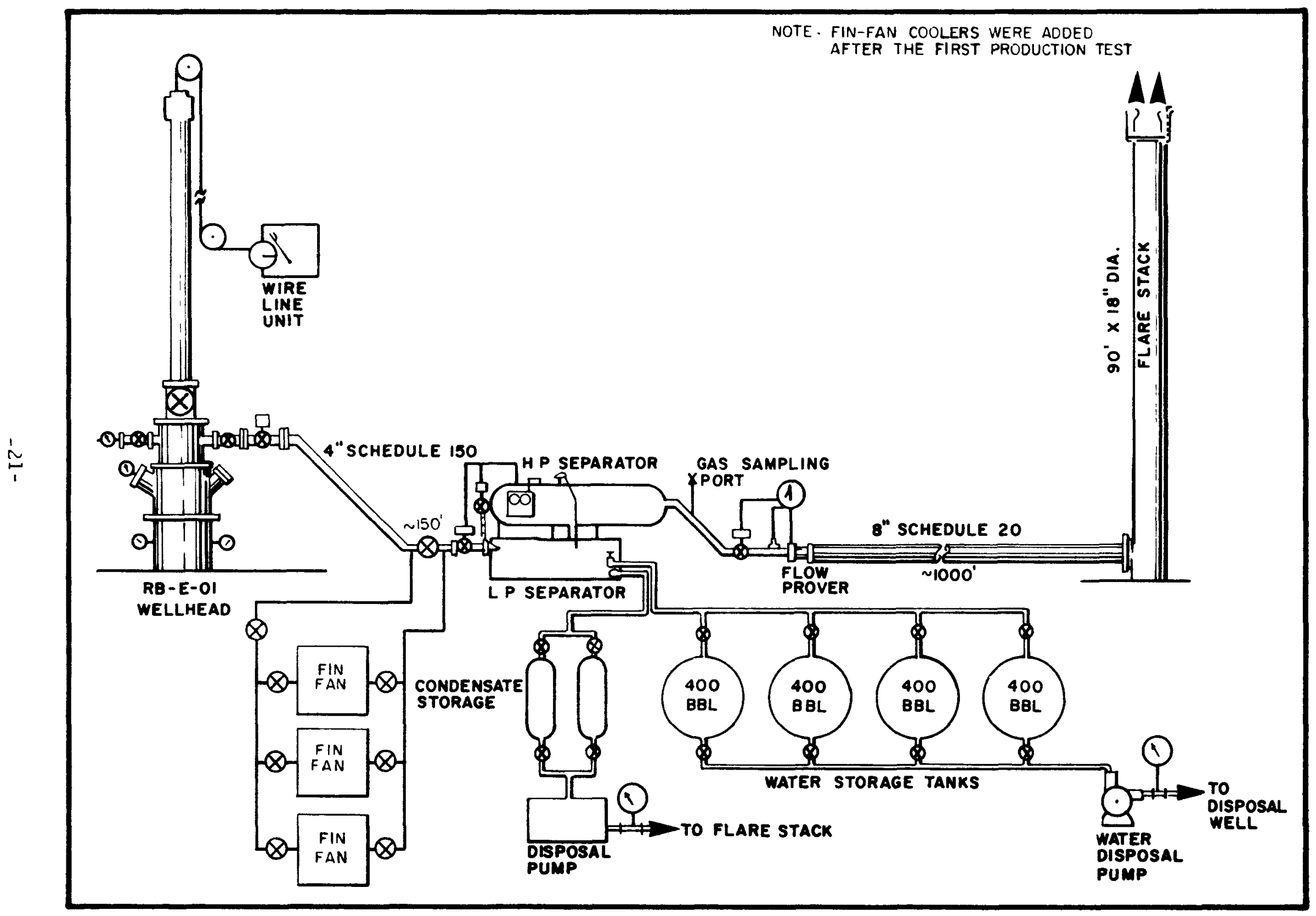

Figure 10. Flow configuration during production tests. 
The wellhead configuration was modified for production testing and handling of the downhole pressure and temperature instruments as indicated in Figure 11. With winter approaching, it was necessary to apply heat tape, insulation, and a weatherproofing material to all flow lines (such as piping, valves, pumps, and filters) which would contain water prior to the start of production testing. These flow lines were:

1. Separator water outlet to the water storage tanks.

2. Interconnecting piping between the four water storage tanks.

3. Water storage tank outlets to and including water disposal pump, filters, and water disposal line to Fawn Creek Government Number 1 Well, about $1,300 \mathrm{ft}$ away.

4. Separator condensate outlet to the condensate storage tanks including a bypass line to the water storage tanks. This line was protected since during the first production testing the high temperature of the gas stream was causing water vapor to appear in the condensate portion of the separator. Upon discharging from the separator to the condensate storage tanks, the water was subject to freezing.

5. Wet gas sampling lines at the wellhead.

6. Water line from water supply well RB-D-01 to the fresh (uncontaminated) water storage tank.

7. RSC gas sample line from sampling ports downstream of separator to the gas conditioning skid adjacent to the RSC laboratory trailers.

Before the start of production testing, drip pans had been installed in the wellhead cellar, under the separator and the water disposal pump, and in a decontamination area.

At the conclusion of the production testing, drip pans were cleaned and contaminated items were put in barrels and stored for future disposal.

Sampling ports were provided to allow collection of fluid samples at the following locations

1. Fawn Creek Government Number 1 Well natural gas supply could be sampled near the EW wellhead fixture, while associated water could be sampled at the Fawn Creek separator.

2. The emplacement well nuclear stimulated gas could be sampled at a EW wellhead fixture, downstream of the separator, and downstream of the critical flow prover. 


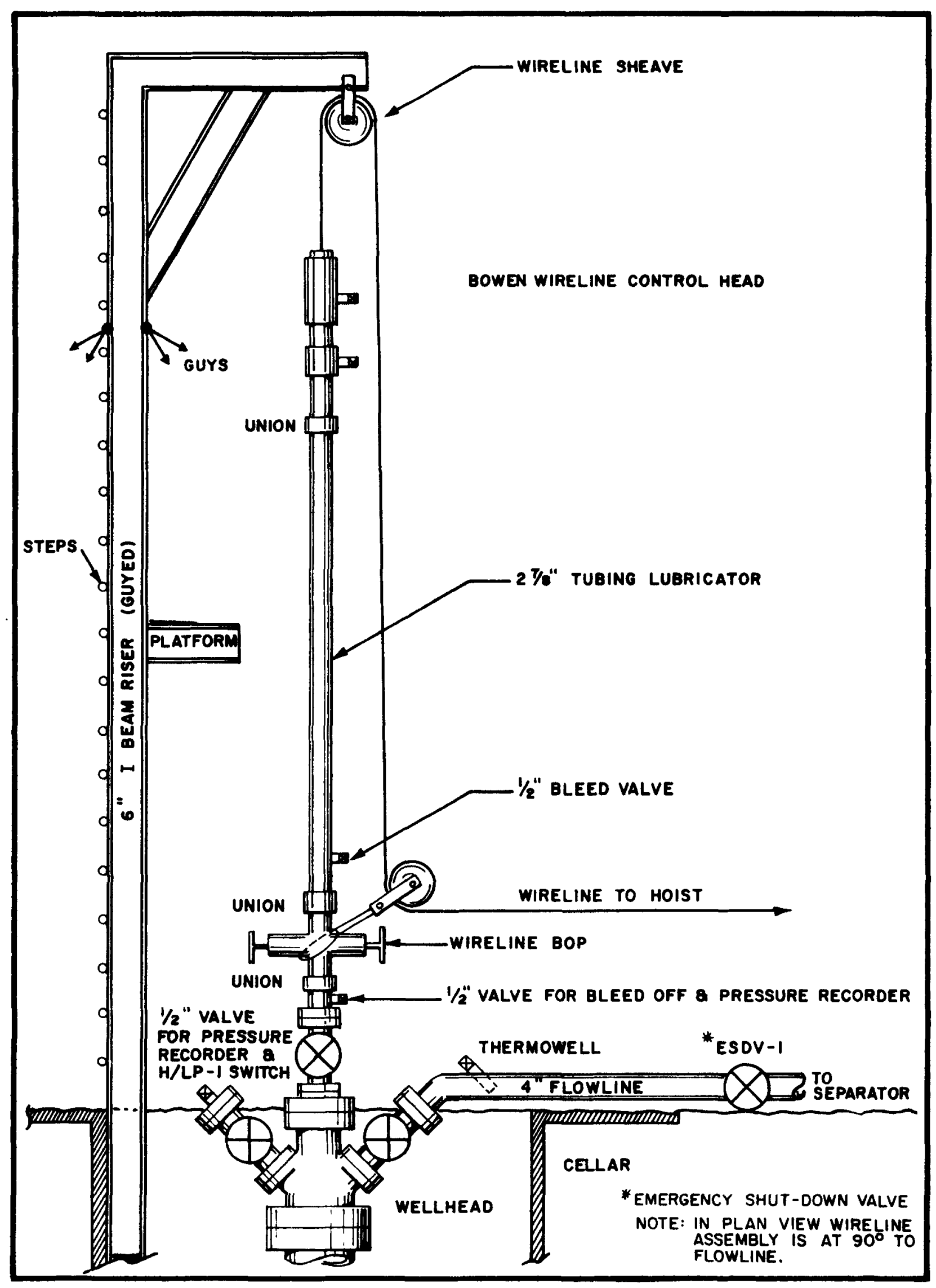

Figure 11. Schematic of RB-E-01 wellhead and lubricator for production testing. 
3. Condensate sampling ports were located at the condensate storage vessles and the separator.

4. Water sampling ports were provided on each water storage tank, at the separator, and on the eight-in. flow line to flare stack.

\section{4 TEST SCHEDULE}

FLOW RATE AND DURATION

The original test schedule called for one flow period lasting 10 days at a constant rate of approximately $30 \mathrm{MMSCFD}$ followed by a long-term buildup. However, the conditions encountered dictated otherwise and the test schedule was modified as the first flow period was in progress.

The initial flow rate, beginning at 1245 hours on November 14, 1973, was approximately 5 MMSCFD. At 1440 hours, the flow rate was increased to approximately $15 \mathrm{MMSCFD}$. At 1500 hours, the emergency shutdown valve automatically shut in the well because of a false alarm. At 1550 hours, the well was again flowing at approximately 15 MMSCFD. At 1750 hours, the flow rate was increased to $24 \mathrm{MMSCFD}$; however, lift off and flame out of the gas stream was occurring at the flare stack. At 1800 hours, the flow rate was reduced to approximately 15 MMSCFD. From 1900 to 2200 hours, a steady flow rate of approximately 15.4 M.MSCFD was maintained. At 2200 hours, the well was manually shut in because of operating difficulties.

It was necessary to stop the production test from 2200 hours, November 14, to 1135 hours, November 16, 1973, to correct some of the operating difficulties resulting from high temperatures. The corrective actions were as follows:

1. The separator was partially plugged and was cleaned.

2. A regulator on the separator was leaking water (steam) and this was corrected.

3. A valve on the separator was leaking through its plug seal and would not completely shut off the flow. This condition was partially corrected.

4. The emergency shutdown valve at the well was inoperable since it was in a bind because of thermal distortion of the flowline. This condition was corrected.

The production testing resumed on November 16, 1973, at 1135 hours, and was concluded on November 20, 1973 at 1007 hours because of the high operating temperature and the significant decrease in bottom hole pressure. During the initial production and testing of the gas, November 14 through 20 , 
1973 (with the exception of down time from 2200 hours, November 14 to 1152 hours, November 16, 1973), the operating temperature of the separator steadily and gradually increased to a maximum of $345^{\circ} \mathrm{F}$ just prior to shut in on November 20,1973, as shown in Figure 12. The temperature of the flowing gas at the wellhead was approximately $25^{\circ} \mathrm{F}$ higher. The time history of the bottom hole pressure and temperature during the same time period is shown in Figure 13. The pressure and temperature data are presented in Appendix D-1.

During the production testing, hydrogen sulfide gas $\left(\mathrm{H}_{2} \mathrm{~S}\right)$ was detected in the gas stream. Its odor was evident at the $\mathrm{EW}$ pad and its source was found to be the elevated exhaust of the sample gas at the RSC laboratory trailers. Increasing the elevation of the exhaust eliminated the odor. However, in the interest of personnel safety, a hydrogen sulfide detection instrument with alarm was procured and installed in the vicinity of the personnel trailers. It was also necessary to replace the carbon steel wire on the wire line unit used to suspend the pressure and temperature instruments within the well with stainless steel wire. $\mathrm{H}_{2} \mathrm{~S}$ causes embrittlement and probable failure of carbon steel wire which might have resulted in the loss of the instruments downhole.

At the conclusion of the first production test, steps were taken to decontaminate the various items of equipment such as the separator, wellhead, cellar and other appurtenances in the wellhead area, drip pans, condensate storage, and the water storage areas.

One valve on the separator was found to be badly eroded and was replaced. Other valves checked were found to be satisfactory as well as all other production test equipment.

The data obtained during the first production test, including the analyses of gas samples taken periodically during the flow test, provided no evidence of flow communication between the top chimney and the lower ones. The rate of decrease was consistent with communication with only the top chimney. Analysis of the produced gas failed to reveal any significant quantity of tracer gas which had been added to the middle chimney.

During the period between the two production tests (November 21, 1973 to January 28, 1974) three fin-fan coolers were added in parallel into the gas flow stream between the wellhead and the separator to solve the hightemperature operating condition problem. The addition of the three fin-fan coolers was found to provide adequate cooling of the produced gas. With the fin-fan coolers in operation, the separator operating temperature was generally in the range of $105^{\circ} \mathrm{F}$ to $150^{\circ} \mathrm{F}$, and never exceeded $180^{\circ} \mathrm{F}$, well within the normal temperature operating range of the separator, even though the flowing gas temperature measured at the wellhead increased rapidly and remained close to $400^{\circ} \mathrm{F}\left(204^{\circ} \mathrm{C}\right)$. The time history of the temperatures is shown in Figure 14. 


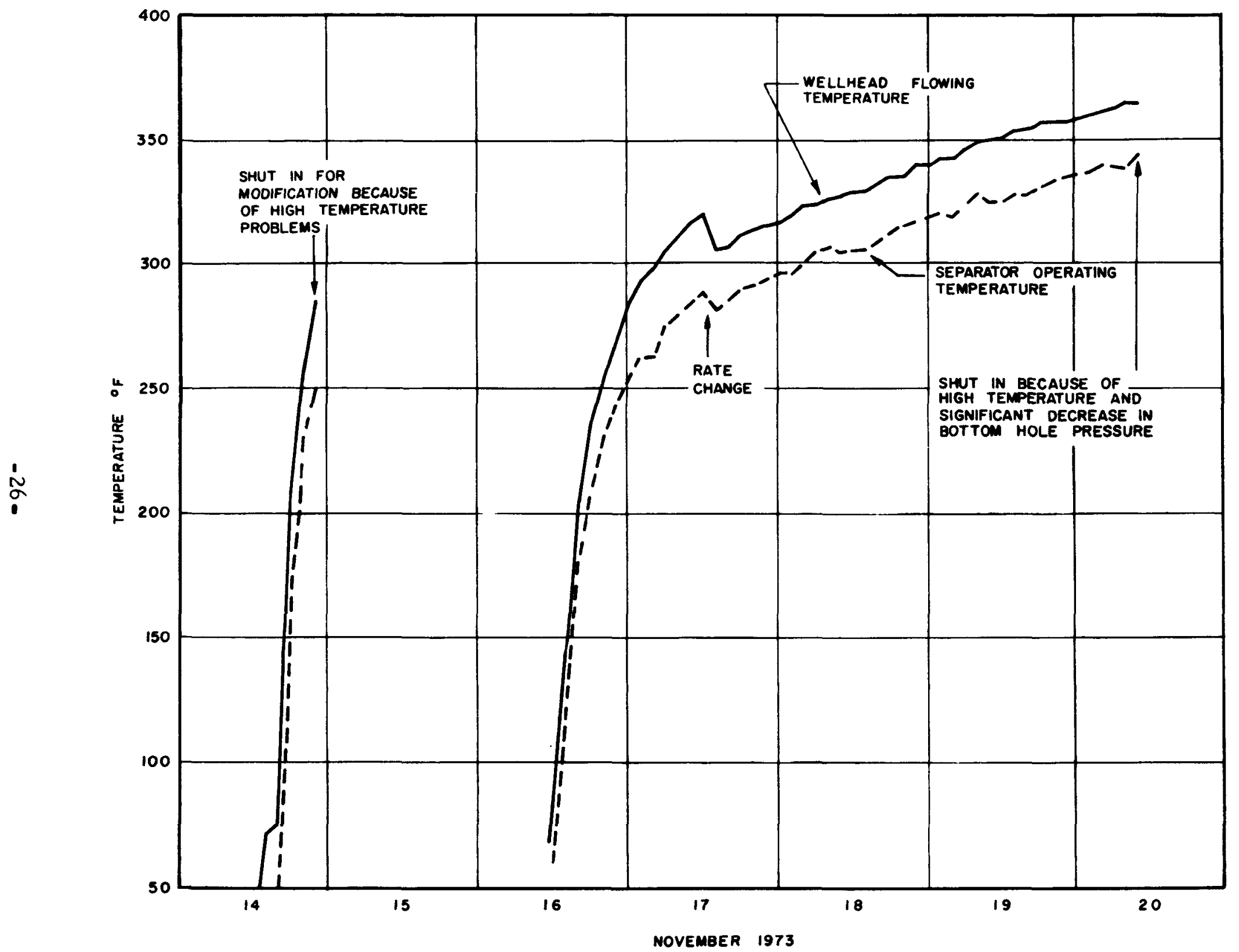

Figure 12. Time history of operating temperatures, first production test. 


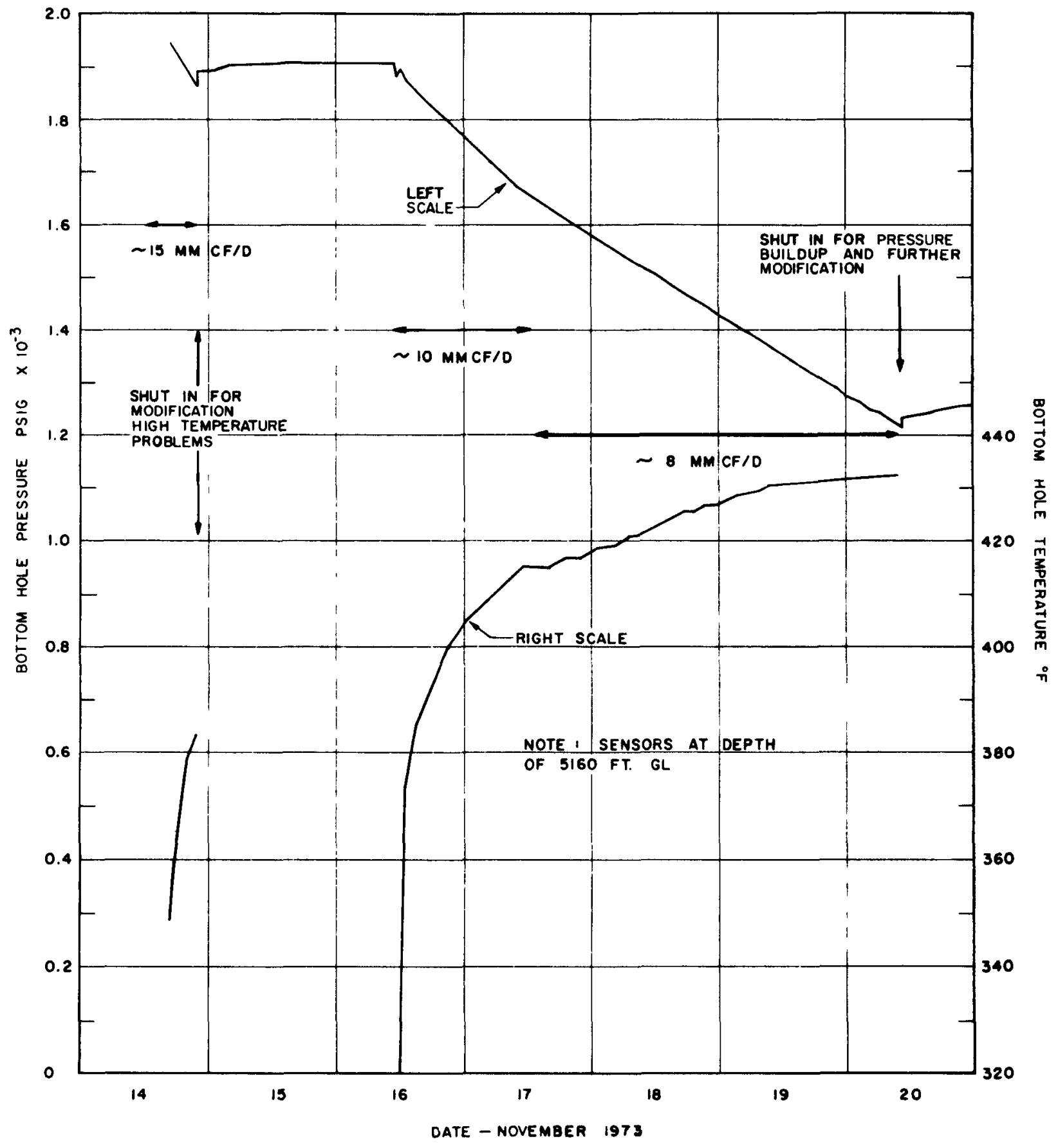

Figure 13. Time history of bottom-hole pressure and temperature, first production test. 


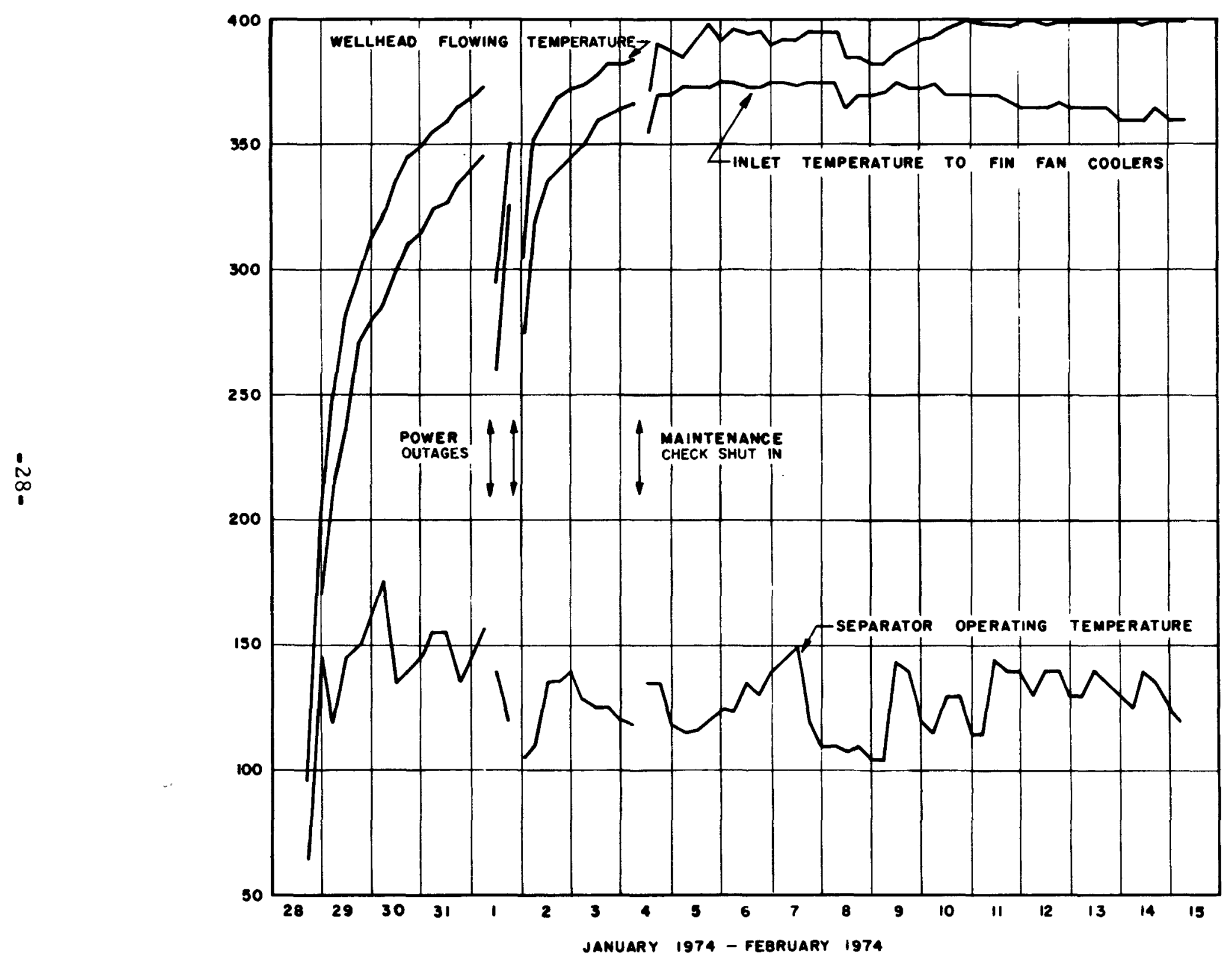

Figure 14. Time history of operating temperatures, second production test. 
Also during the second flow test, commercial electric power failed twice (blown fuses due to overload) on February 1, 1975, for a few hours and production testing was halted because the fin-fan coolers and the water injection pump were inoperable. After the second fuse failure, a larger transformer was installed to power the fin-fan coolers and the water injection pump.

However, general concern was expressed about the possibility of a total commercial power failure which would result in all the water flow lines being without electrical power for the heat tapes and thus being subject to freezing and bursting. A 37.5-kVA generator was connected in a standby configuration through a manual transfer switch to the electric distribution panel so that, in the event of a commercial power failure, the heat tapes on the water lines on the EW pad would continue to protect the lines. The alarm and control panel, minimum exterior lighting, and personnel trailers were also placed on this circuit. Sufficient power would not be available from this standby generator to operate the water injection pump, fin-fan coolers, or heating tapes on the water disposal line to the Fawn Creek Government Number $1 \mathrm{Well}$. Therefore, these operations would necessarily cease until commercial electric power had been restored.

Bottom hole pressure was monitored during the pressure build up following each of the two production tests of RB-E-01. The data for the first build up, from November 20, 1973, to January 28, 1974, are listed in Appendix D-2 and are plotted in Figure 15. The pressure and temperature data for the second drawdown and the pressure data for the following pressure build up are shown in Figures 16 and 17, respectively. The pressure and temperature data for the second drawdown are listed in Appendix D-3, while those for the second build up are given in Appendix D-4.

Monitoring of the bottom hole pressure build up after the second drawdown was terminated on June 24, 1975, 494 days after shut in.

With respect to water production at the separator during drawdown of the RBE-0l Well from the nuclear chimney, the predetonation predictions contained in Volume III of Reference 2 postulated that about $20 \mathrm{bbls}, 7,000 \mathrm{lbs}$, of free water would be produced with each million SCF of total gas flowed. This prediction was based on published data(4) of water content of natural gas and on the assumptions that the initial downhole pressure and temperature were 2500 psi and $450^{\circ} \mathrm{F}$, respectively, and that the separator was operated at $1000 \mathrm{psi}$ and $300^{\circ} \mathrm{F}$. The prediction also assumed a pressure drawdown of about 30 percent. It was found during the first production test that the downhole pressure was about 80 percent of the assumed value but that the bottom hole temperature was close to the assumed $450^{\circ} \mathrm{F}$. The lower initial bottom hole pressure resulted in the production of water at an initial rate of about 10,700 lbs/MMSCF total gas, increasing to $16,600 \mathrm{lbs} / \mathrm{MMSCF}$ total gas at the end of the first drawdown. During the second drawdown, which was continued until the total gas leaving the chimney was over 80 percent steam, the water 


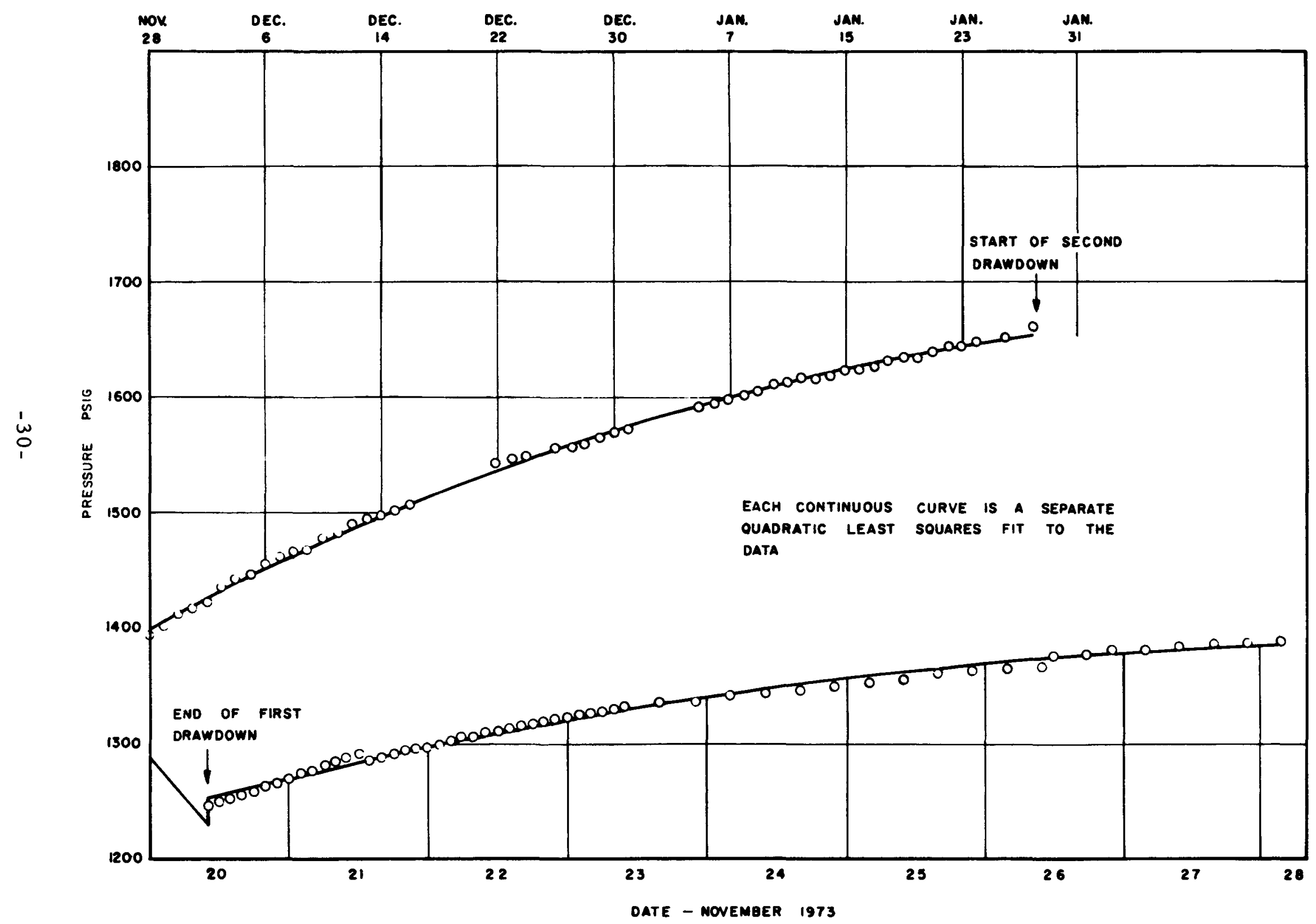

Figure 15. Bottom hole pressure buildup, RB-E-01, after first production test. 


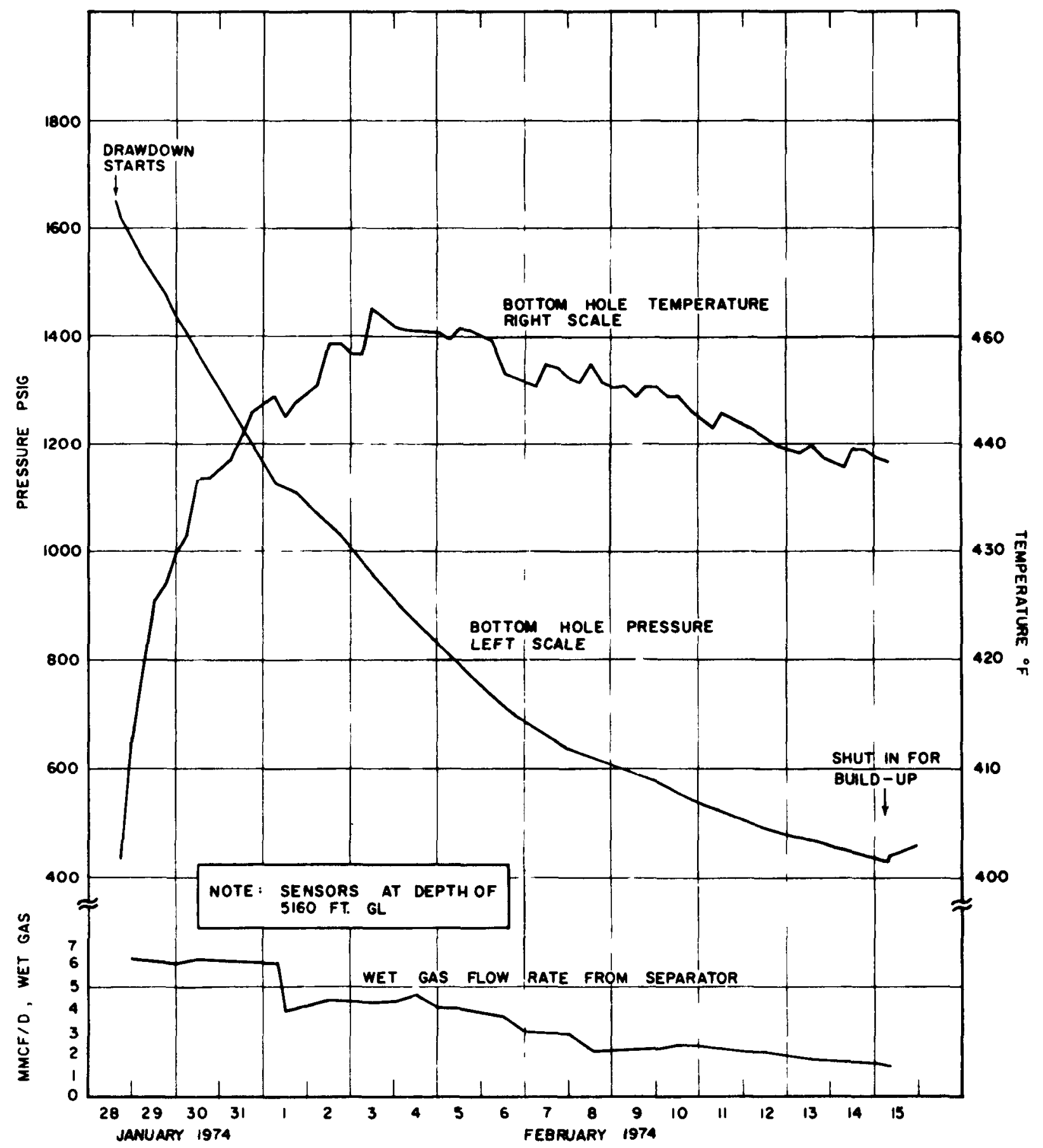

Figure 16. Time history of bottom hole pressure, temperature and flow rate, second production test. 


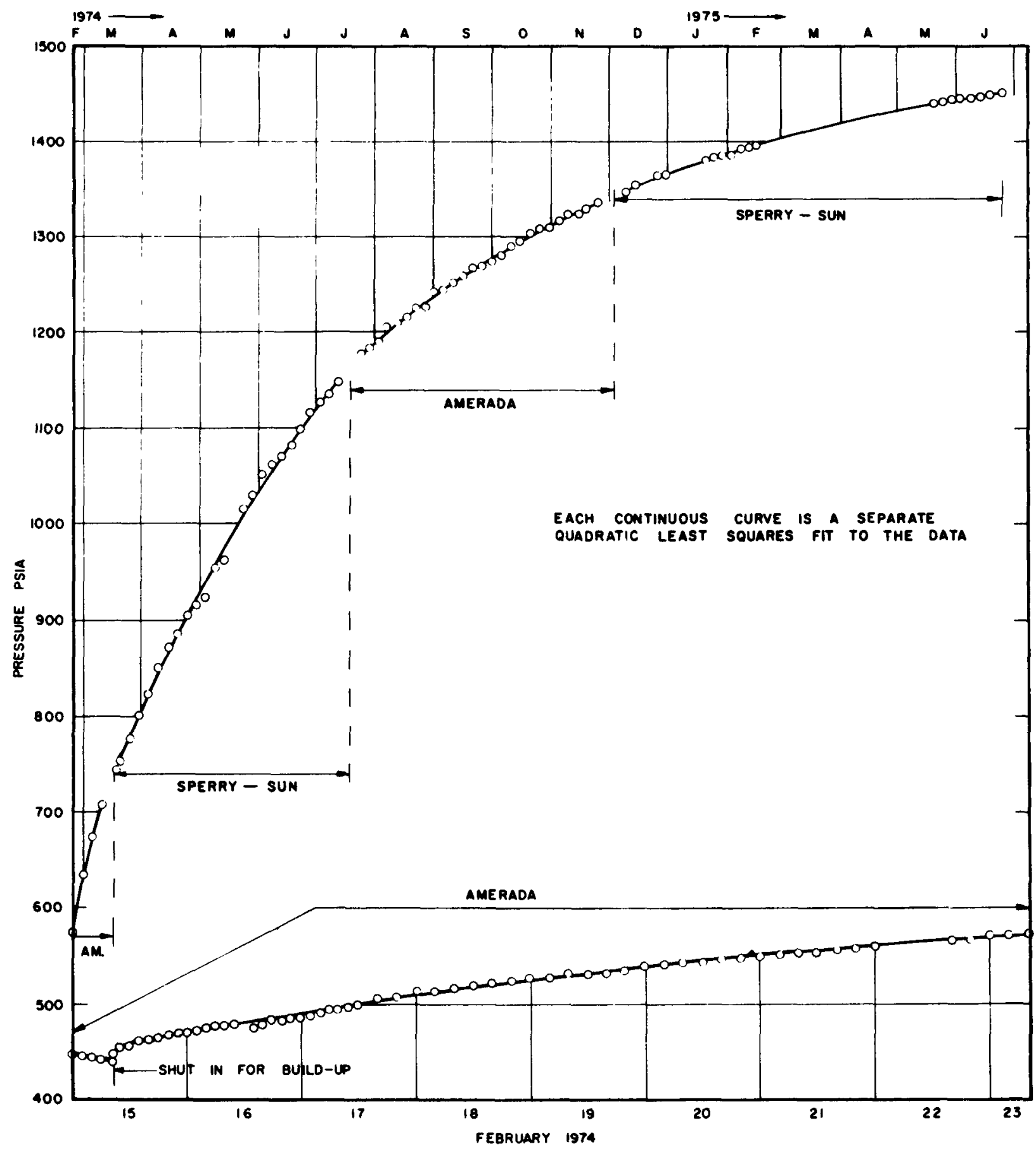

Figure 17. Bottom-hole pressure buildup, RB-E-01, after second production test. 
production rate climbed steadily to 38, $200 \mathrm{lbs} / \mathrm{MMSCF}$ total gas. The time history of the ratio of water produced to total gas volume is shown in Figure 18, with correlative bottom hole pressures.

\section{5 \\ AUTOMATION AND ALARM SYSTEM}

\subsubsection{Instrumentation}

In many locations it was possible to use visual monitoring, of a sight gauge such as a thermometer or sight glass, to determine whether operating conditions were satisfactory. However, experience has taught that thermometers can malfunction and the sight glass become opaque, misleading operating personnel into believing that operating conditions were satisfactory where in reality danger existed. For this reason, instrumentation for the production testing was duplicated in many instances. As an example, temperature of the gas flowing from the wellhead was observed on a direct reading mechanical thermometer; however, a few feet away was a high-temperature automatic shutdown switch, thermostat controlled (electronic), connected to the alarm panel and emergency shutdown valve at the wellhead. Thus, the mechanical thermometer could fail but the operating personnel would be aware of the automatic shutdown from a high-temperature condition. These systems were tested prior to production of the well to ensure their operation.

\section{4. $5.2 \quad$ High-and Low-Level Alarms}

The high- and low-level alarm instrumentation consists of a float switch which activates a signal lamp at the control panel. The high- and low-level switches were used in each of the four water storage tanks. The high-level alarm would indicate the tank was full and no further filling should occur or the tank would overflow via piping to the next tank, etc., until all four alarms were activated. Additional filling would trigger the fifth alarm which would automatically shut in the well before spilling out of the tankage could occur.

The low-level alarm was also used in each of the four water storage tanks to indicate to the personnel that a tank was empty. The alarm automatically shut down the high-pressure water disposal pump. There was also a visual gauge on the exterior of the tanks that indicated depth of fill.

The two condensate storage vessels had instrumentation similar to that on the water storage tanks; i.e., high-and low-level signals, high-level automatic shutdown and a sight glass to determine depth of fill.

The high-pressure water disposal pump was equipped with a high- and lowpressure limit switch. The high-pressure switch was preset in order not to overpressurize the disposal well or interconnecting piping. The switch also reacted on startup if the water disposal line froze or the water filters were plugged by immediately shutting down the pump. The low-pressure switch would indicate a ruptured line and stop operation of the pump. 


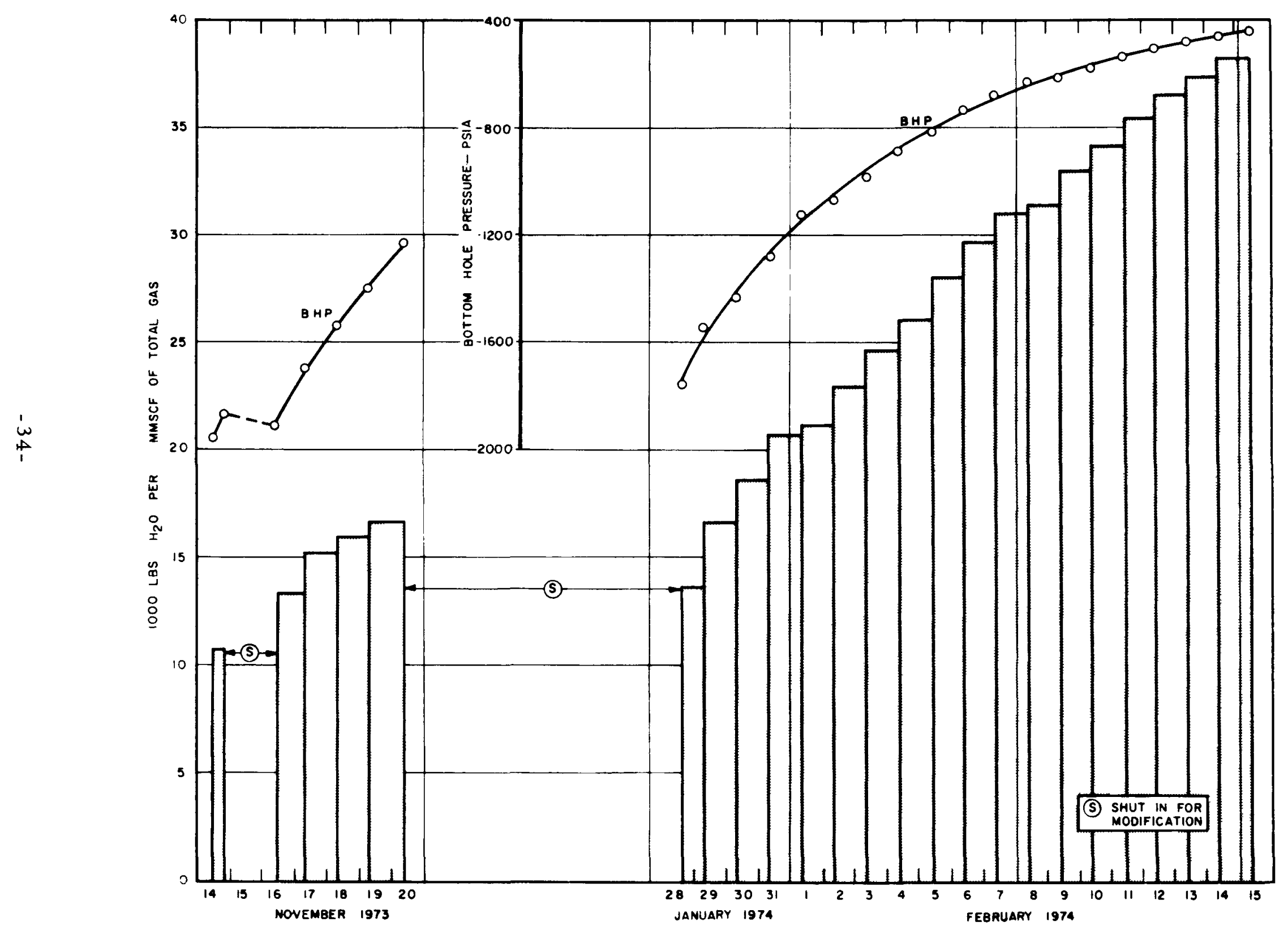

Figure 18. Time history of water production (kilopounds) per unit volume (MMSCF) of total gas flow, with correlative bottom-hole pressures. 
The flare stack ignition system utilized electrical arcing to ignite the pilot gas and flame sensors detecting heat from the pilot flame controlled the electrical arcing. If the pilot flames were extinguished, the heat sensor automatically started the ignition sequence again, and activated an ala rm light on the alarm panel until the pilot flame was re-ignited.

The Alarm and Control Panel (Figure 19) controlled and monitored the safety functions during the production testing of the well. The separator was equipped with three safety devices. A low-pressure switch would be activated if there were a rupture in the system and the well would be shut in.

A high-pressure switch would also shut in the well if there were no downstream flow past the separator. This could be caused by freezing, plugging, or closing the flow line choke valve downstream of the separator. A flow switch would be activated. If the pressure relief disc were to rupture and allow the gas to flow through the separator to the flare stack without removing the liquids, the well would be shut in by the consequent activation of a flow switch.

A high- and low-pressure switch was installed at the wellhead. The lowpressure switch would be activated by plugging of the well or rupture of the surface piping system and would shut in the well. The high-pressure switch was preset in order not to overpressurize the piping and equipment downstream of the well. The well would also shut in if the switch was activated.

The principal control valve for shutting in the well automatically is the emergency shutdown valve located immediately downstream from the wellhead. This valve requires pneumatic pressure to operate and was therefore connected to the instrument control gas supply. Loss of gas pressure automatically closes the valve. The valve is electrically controlled from the alarm and control panel. In addition to this emergency shutdown valve, a shutdown valve was located at the inlet of the separator, water disposal system, and condensate disposal system. Any malfunction, whether true or false, that triggers the emergency shutdown valve also closes the additional shutdown valves. A bypass switch was installed so that the water disposal system could operate even though the well was shut in.

\section{6 OPERATIONAL PROCEDURES}

Two persons were on duty around the clock during the production testing of the well. The two personnel monitored the production equipment for normal functioning and recorded data and operating details for evaluation. In the case of an emergency, two persons could take corrective actions more quickly than one. In any event, the presence of $\mathrm{H}_{2} \mathrm{~S}$ required that two persons be on hand as a safety measure.

During the production testing of the well, the following data were recorded on an hourly basis by the operations personnel: 


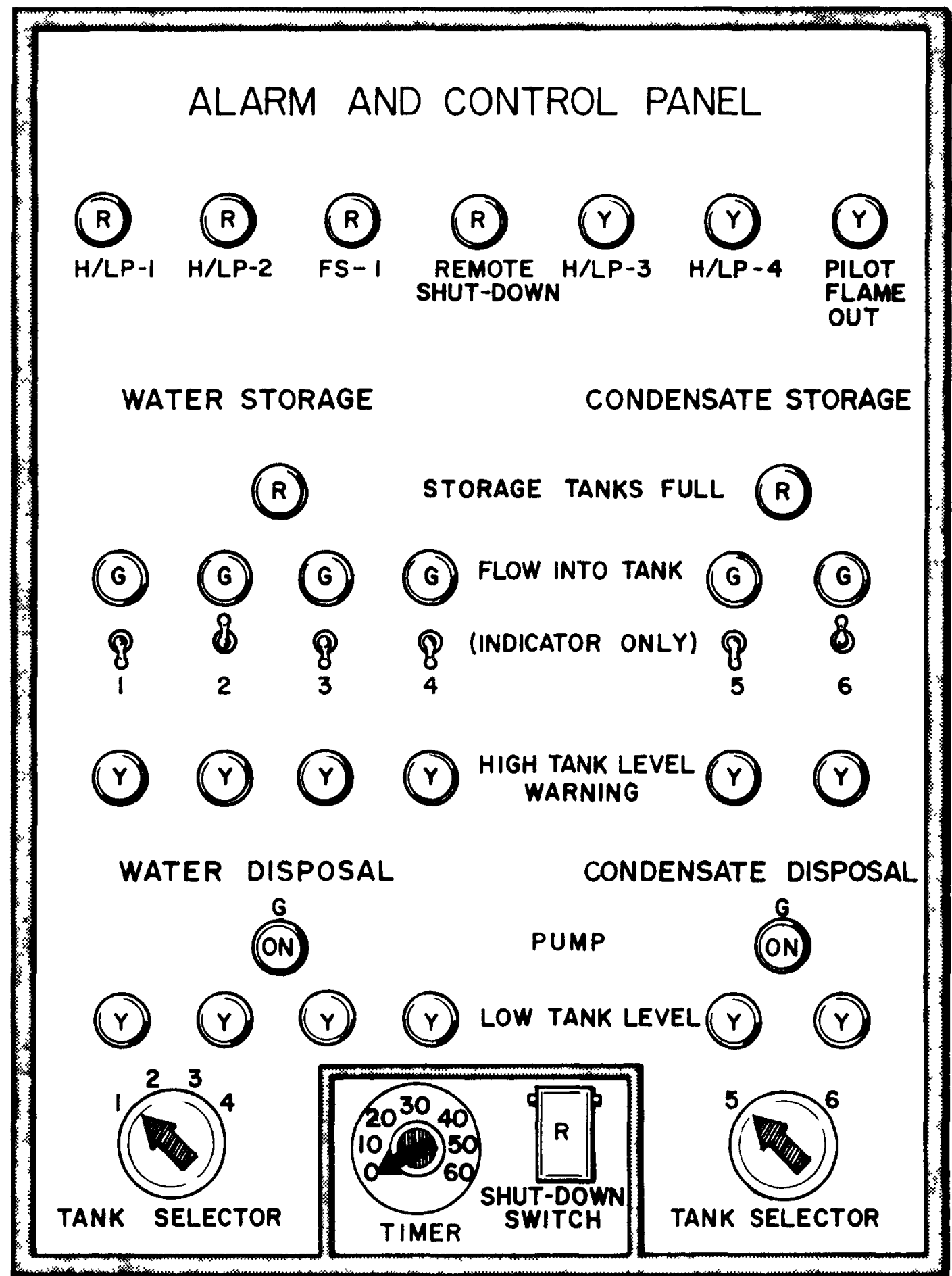

$R=R E D$

$Y=Y E L L O W$

Figure 19. Layout of the Alarm and Control Panel. $G=$ GREEN 
1. Date

2. Time

3. Operators initials

4. Wellhead readings
a. Casing pressure in psig
b. Tubing pressure in psig
c. Flowing temperature in degrees $F$.

5. Separator Readings
a. Instrument gas pressure in psig
b. Operating temperature in degrees $F$.
c. Operating pressure in psig
d. Cumulative water production in barrels
e. Tank number receiving water
f. Cumulative condensate production in barrels
g. Tank number receiving condensate
h. Remarks

6. Fin-Fan Coolers (second production test only)
a. Inlet temperature in degrees $F$.
b. No. 1 outlet temperature in degrees $F$.
c. No. 2 outlet temperature in degrees $F$.
d. No. 3 outlet temperature in degrees F.

7. Main Gas Line Orifice Readings
a. Plate sizes
b. Upstream pressure in psig
c. Upstream temperature in degrees $F$.
d. Downstream pressure in psig

8. Wet gas flow rate in MMSCF/D

9. Specific gravity relative to air of gas

10. Water tank levels
a. Water tank \#l depth measurement in feet
b. Water tank \#2 depth measurement in feet
c. Water tank \#3 depth measurement in feet
d. Water tank \#4 depth measurement in feet

11. Condensate tank levels

a. Condensate tank \#5 depth measurement in feet

b. Condensate tank \#6 depth measurement in feet 
12. Water injection system readings

a. Water pump injection pressure in psig

b. Cumulative water injection amount in barrels (two meters)

c. Suction tank number

13. Condensate injection systems readings. These data (similar to those for the water injection system) were not taken because no condensate was found during the production tests. However, the pump and meters were used, and data recorded, for transfer of dilution water to the water tank being used during part of the first production test to minimize boiling of the separated water.

Considerable use was made of telecopiers to transmit data and other documents to the GJCP and elsewhere. Production test data generated by the operations personnel in the field were sent via telecopier to the GJCP where the data was typed on the appropriate forms, telecopied to the EW for approval, and then transmitted via mail or telecopier to interested project participants.

A copy machine located in the office trailer at the EW provided copies of approved data to interested project participants in the field.

4.7 CIAS I IPPLY/WATFR DISPUSAL WELL

She fawn Cretk (iovernment Number I well, located about $1,340 \mathrm{ft} S 18^{\circ} \mathrm{W}$ of the EW, was stemmed prior to the detonation of the nuclear explosives as a containment precaution. A Baker Model D packer was set at $5,653 \mathrm{ft} \mathrm{KB}$. A Baker Model C retrievable bridge plug was set at 5,580 ft KB. The well was then stemmed with sand to $5,530 \mathrm{ft} \mathrm{KB}$ and cement to $4,377 \mathrm{ft} \mathrm{KB}$.

As tentatively planned, the well was reentered in June, 1973, and recompleted in September, 1973, as both a gas producing well and a contaminated-water disposal well. Reentry operations commenced on June 19, 1973. The top of soft cement was tagged at $4,364 \mathrm{ft} \mathrm{KB}$ and the cement was drilled out with no problems until a depth of $5,524 \mathrm{ft} \mathrm{KB}$ was reached on June 26, 1973, when the bit encountered metal. The problem was identified as collapsed casing at and below the bottom of the cement plug. Twenty-one more days of milling through the collapsed section, which had a minimum apparent bore of 3-1/2 in., were required to tag the Model $D$ packer at $5,654 \mathrm{ft} \mathrm{KB}$. Attempts to remove the Model $D$ packer were unsuccessful, as also were attempts to mill out the bottom slips and allow the packer to drop down hole. The packer was finally left open at a depth of $5,667 \mathrm{ft} \mathrm{KB}$.

The well was first recompleted on August 4 with a Baker Lockset packer on $2-1 / 16-i n$. lubing set at $4,643.5 \mathrm{ft} K B$ and $1.9-1 \mathrm{n}$. tubing run to 5, 572 ft KB. Attempts to brige the well itc produrtion trom the perforated zone. 5, 600 to 
$5,630 \mathrm{ft} \mathrm{KB}$, including an acidizing treatment of the zone on August 24, were nut successful and the decision was made about August 31 to kill the well for a planned fracture of the zone 5,082 to $5,128 \mathrm{ft} \mathrm{KB}$. This was arcomplished un September 8 and the well flowed back successfully. On September 12 the well was tested through a critical flow prover at rates up to about $500 \mathrm{MCF} / \mathrm{D}$.

The well was again killed and recompleted with a Baker Model FH hydrostatic packer on 2-1/16-in. tubing set at 5,293 ft KB. A Baker F plug nipple was located at 5,288 ft KB. The 2-1/16-in. tubing was hydrotested joint by joint as it was run in the hole. Two bad joints were rejected. The 1.9-in. tubing for gas production was run in and landed at 5,084 ft KB. The well was swabbed in and flowed to the pit to clean up. At the time of shut in on September 17, 1973, the estimated flow rate was $450 \mathrm{MCF} / \mathrm{D}$.

The detailed daily drilling reports are given in Appendix B. The as-built downhole completion detail is shown in Figure 20.

After the workover rig was removed, the wellhead was enclosed in an insulated wood-frame structure and an explosion-proof electric heater was installed for the winter operations. A conventional 3-phase separator was installed on the Fawn Creek Government Number 1 Well pad and connected to the wellhead fixture to supply gas for the Project Rio Blanco production and testing program. Two high-pressure pipe lines were laid to the EW trea, one tor the nati.ral uas supply and the second for the water disposal line. The water disposal line was heat taped, insulated, and wrapped with plasti, sheeting to weatherproof the insulating material.

Use of the Fawn Creek Government No. 1 well as a disposal well for contaminated water separated out during the two productions required the permission of the Colorado Water Quality Control Commission, and the consequent issuance of a permit by the Colorado Department of Health. Application for such a permit was made on June 11, 1973, and a public hearing held before a Hearing Officer for the Water Quality Control Commission on September 24, 1973. The text of the Findings of Fact by the Hearing Officer and of the Permit for Subsurface Disposal, which was issued on November 9, 1973, are given in Appendix $C$. The principal stipulations of the permit were that the volume of water injected could not exceed $24,000 \mathrm{bbls}$ and the tritium concentration could not exceed 0.05 microcuries per milliliter $(\mu \mathrm{Ci} / \mathrm{ml})$ while the injection pressure could not exceed 1800 psig.

During the first production test, about $1873 \mathrm{bbls}$ of water were produced at the separator and stored for analysis prior to disposal. Dilution of the produced water with fresh water to drop the temperature below the local boiling point $\left(200^{\circ} \mathrm{F}\right)$ and decontamination of equipment raised the volume of water to be injected to $3378 \mathrm{bbls}$, with an average tritium concentration of 0.029 $\mu \mathrm{Ci} / \mathrm{ml}$, well within the disposal permit limitations.

During the second production test, when the bottom-hole pressure was allowed to drop to a value iust above the steam point, about $11,470 \mathrm{nbls}$ of 


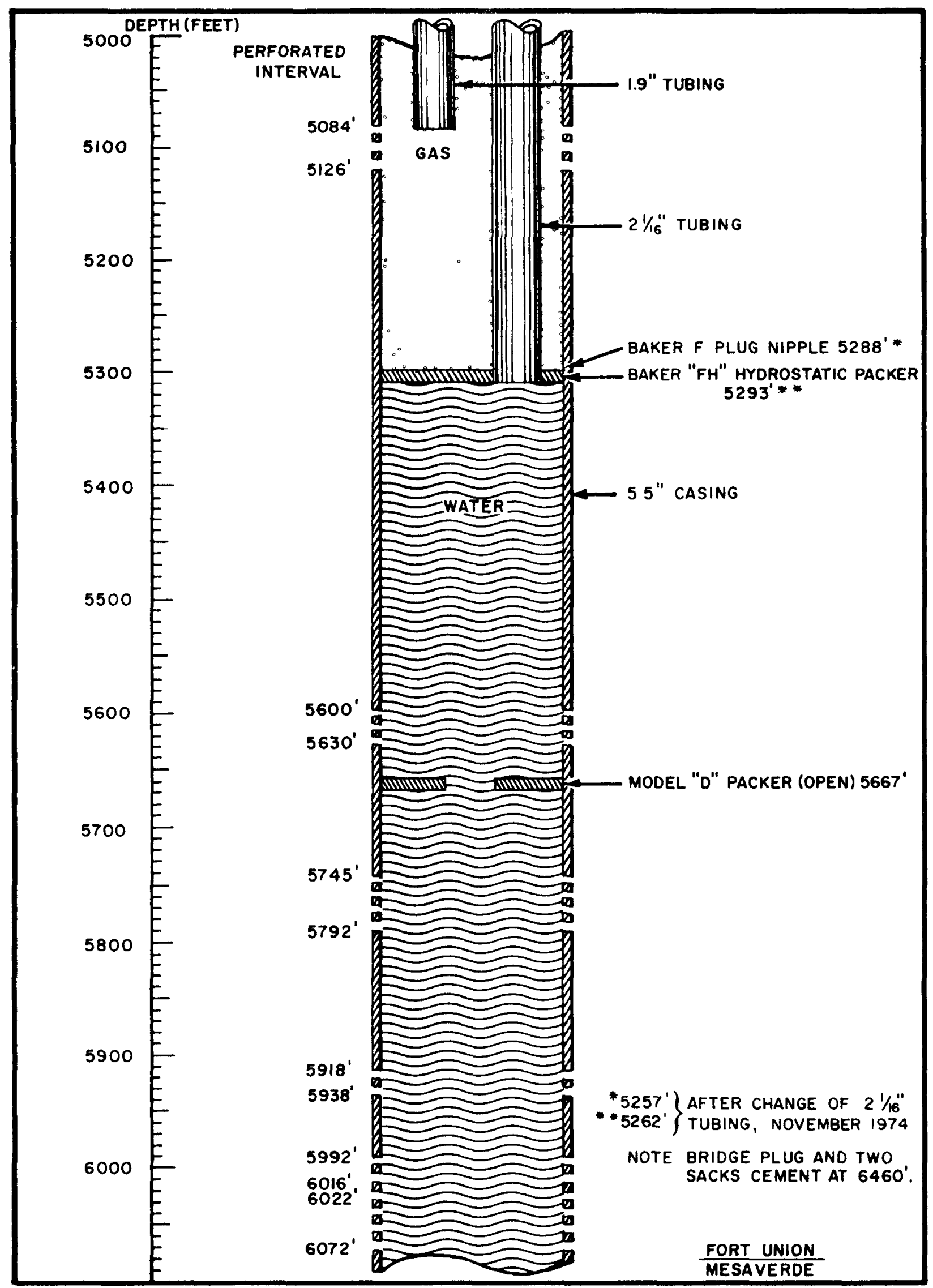

Figure 20. As-built downhole completion detall, Fawn Creek Government No. 1 Well. 
water were separated and stored for analysis and subsequent disposal. The Colorado Water Quality Contrul Division was requesied on January 16, 1974 to relax the limit on tritium concentration from $0.05 \mu \mathrm{Ci} . \mathrm{ml}$ to $0.075 \mathrm{M} \mathrm{Ci.ml,}$ in the light of expert testimony before the Hearing Officer that the value of $0.05 \mu \mathrm{Ci} / \mathrm{ml}$ was a best estimate with some probable error. The request was denied, however, unless further public hearings were held on the question. Because completion of preparations. for the second production test was imminent, the decision was made to proceed under the existing limitation, and to dilute the water to the required concentration upper limit. Accordingly, a total of $17,459 \mathrm{bbls}$ were injected during the second production test with an average tritium concentration of $0.048 \mu \mathrm{Ci} / \mathrm{ml}$. Withuut dilution, the average tritium concentration of the separated water was $0.074 \mu \mathrm{Ci} / \mathrm{ml}$, just under the proposed amended value. The cost of the additional effort required to dilute has not been evaluated, but it was certainly a small fraction of the costs of additional public hearings, legal fees, and personnel, and other costs associated with project delays.

During the course of the second production test, some tenuous evidence was obtained that small amounts of tritium were being found in liquids produced with the gas from the Fawn Creek Government No. 1 well. After completion of laboratory analyses of gas and water samples and evaluation of the data, it was concluded ${ }^{(5)}$ that the data were inadequate to determine the source or magnitude of the observed tritium activity or the mechanism for the occurrence of the activity in the produced liquids.

To answer the questions, tests were performed on the well over the period April 5-11, 1974, inclusive. A plug was set in the injection string on April 5, 1974; the string was pressurized with fresh water and the pressure recorded for a period of 88 hours. A pressure drop was observed which was equivalent to a leak rate of one gallon per day flowing into the gas producing annulus. The well was flowed to the mudpit for a period of 48 hours, and was periodically sampled for tritium in the gas and in the water. All gas samples were negative with respect to tritium. The initial water samples showed tritium concentrations in the neighborhood of $2500 \mathrm{pCi} / \mathrm{ml}$. The concentration decreased to one-third of that value by the end of the test.

Evaluation of the tritium concentrations and the volumes of water involved lead to the conclusion that the data were consistent with the leak rate of one gallon per day observed in the pressure test.

Remedial action was later taken in November-December 1974, prior to resumption of further testing activities in a new sidetracked well, RB-AR-02 (which are beyond the scope of this report), in the form of replacement of the 2-1/16in. injection string. The final downhole configuration is shown in Figure 20. The daily reports for this operation are included in Appendix $B$.

\section{8 SCHEDULE}

The schedule as accomplished of the production testing and pressure buildup monitoring is shown in Figure 21. 


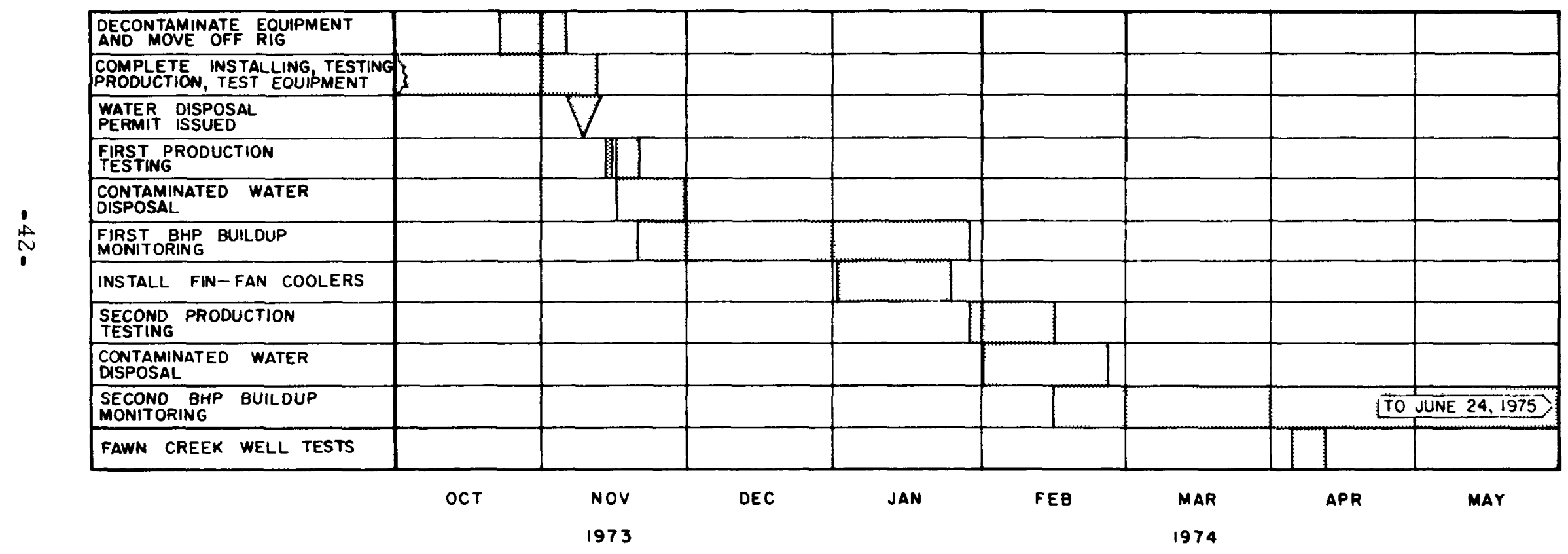

Figure 21. Production testing and pressure buildup monitoring schedule as accomplished. 


\section{RADIOLOGICAL SAFETY AND EFFLUENT DOCUMENTATION}

Radiological protection and documentation of radioactive effluents was provided in a limited way during the programmed waiting period of three months and fully during the reentry drilling and both production test periods. The bulk of the work was performed by the Eberline Instrument Corporation under contract to CER. CER operated its TRY-KRY monitoring system for gaseous effluent documentation during releases through the DWC and during both production test periods. The radiological protection equipment used on the project, apart from the TRY-KRY, was government-furnished from existing equipment on loan to CER. Expendable equipment and supplies was furnished by CER.

\subsection{OPERATIONAL GUIDES}

Radiation exposure criteria and radioactive concentrations guides were governed by AEC Manual Chapter 0524 as augmented by letter, AEC PNE/DAT, "Radiological Safety Guidance for Experiments involving Nuclear Stimulation of Natural Gas Wells," dated April 17, 1972. In the event of accidental or emergency exposure, provisions of both AEC Manual Chapters 0502 and 0524 as augmented by the mentioned letter were to be followed as applicable.

Personnel radiological explosure criteria were that the quarterly whole body exposure should not exceed $3 \mathrm{rem}$, while the annual should not exceed $5 \mathrm{rem}$, with other dose commitments for various parts of the body. In practice, all dose measurements made on project participants were not detectable.

The toxicological exposure criteria were the threshold limit values of toxic materials as recommended by the American Conference of Government Industrial Hygienists or those deriving from the Occupational Safety and Health Act.

Considering only the most likely contaminant to be found, tritium, the criterion for release of vehicles and othe $r$ equipment for public use elsewhere was that any contamination should not exceed 1000 disintegrations per minute (dpm) on any $100 \mathrm{~cm}^{2}$.

\section{$5.2 \quad$ ACCESS CONTROL}

An Access Control trailer was located at the entrance to the EW pad to serve these functions: to act as the central control point for radiological monitoring support operations in the field; to be the source of is sue and supply for radiological safety support items such as portable survey instruments, dosimetric devices, respiratory protection equipment, anti-contamination clothing, and other related supplies; to act as the Access Control Point for personnel and vehicular traffic into "controlled areas" where the presence of dispersed radioactive materials exists; to provide limited dressing and washing facilities 
and supply of full Anti-C clothing for the regular work force on drilling operations when required; and to provide a supply of limited Anti-C clothing for visitors.

The access control trailer remained in the EW area during the programmed delay period, reentry drilling, and the two production test periods.

To ensure that project participants were aware of potential exposures and good practices, EIC routinely provided a radiological safety indoctrination to all workers on site and to new workers as they arrived.

\section{3 PERSONNEL DOSIMETRY AND SIOASSAY}

From the start of reentry drilling through the first production test, a program of personnel dosimetry was conducted which applied to all project participants on site, including visitors. Thermoluminescent dosimeters (TLD's) were issued to each person for wear on site. All badges were readout routinely on a monthly basis or on departure of the participant or visitor from the site. Urine samples were also provided by project participants before reentry drilling and before and after the first production test. Bioassays for ${ }^{3} \mathrm{H}$ were performed on the urine samples. All TLD readouts were background as were all bioassays.

Because of the favorable results during the reentry drilling and first production test, during the second production test, a much more limited program of dosimetry was undertaken. TLD's were issued only to CER and EIC persons having access to radioactive calibration sources. Bioassays were limited to persons handling contaminated materials. Again, all results were background.

EIC maintained all explosure records and furnished them to CER after each production test. CER forwarded the exposure records to the Reynolds Electrical and Engineering Company for inclusion in the NVOO master exposure files.

5. 4 EFFLUENT DOCUMENTATION DURING THE DELAY PERIOD

EIC mounted a beta-gamma radiation detector at the wellhead to monitor for fission product radioactivity, primarily ${ }^{85} \mathrm{Kr}$. The output of the detector was recorded continuously on a strip chart recorder installed in the access control trailer near the EW. The system was alarmed at a preset level and included a fail-safe failure light to indicate malfunction of the detector. The system was inspected daily by a qualified person. EIC manned the EW during daylight hours seven days a week during this period to maintain the detection system and make periodic surveys of the immediate vicinity of the EW. No data above background were obtained during the period. 
During the first 4,700 feet of reentry drilling radiological protection procedures were limited to that described below. No data above background were obtained.

5.5.1 A. RM-3C with a bare Anton 112 beta-gamma detector was provided on the rig floor work area to sense ${ }^{85} \mathrm{Kr}$ or other fission products with continuous recording off the rig. The detector was set to alarm at twice the normal upper limit of background readings.

5.5.2 The output of the shielded scintillation detector on the mud return line was continuously recorded off the rig, with an alarm set at twice the normal upper limit of background readings.

5.5.3 Daily samples of mud and any drill cuttings returned were obtained from the mud return line and analyzed for particulate fission products by gamma spectra at $1-\mathrm{pCi} / \mathrm{ml}$ sensitivity referenced to ${ }^{137} \mathrm{Cs}$ and by liquid scintillation for ${ }^{3} \mathrm{H}$ at $\mathrm{l}-\mathrm{pCi} / \mathrm{ml}$ sensitivity.

5.5.4 Mud and waste water which dripped from the drilling equipment were collected from the cellar or drip pans in a lined pit. Prior to disposal, samples of the collected water were assayed for ${ }^{3} \mathrm{H}$.

5.5.5 A gas flare line monitoring system was installed on the flare line downstream from the DWC unit, to be activated when the DWC unit was used.

5.5.6 A rig air sampler and a site air sampler elsewhere, each consisting of a particulate filter and a charcoal cartridge were continuously operated, with daily change of filters. The particulate filters were analyzed for gross beta and alpha and gamma scanned. The cartridges were gamma scanned.

5.5.7 The rig floor air was sampled for ${ }^{3} \mathrm{H}$ with a molysieve air moisture absorbent. Samples were collected daily and were assayed for ${ }^{3} \mathrm{H}$ by liquid scintillation counting with a sensitivity of $2 \mathrm{pCi} / \mathrm{ml}$ for a $5-\mathrm{ml}$ water sample.

5.5.8 Temperature, barometric pressure, and humidity were recorded to provide necessary data for quantifying site air and rig air samples.

5.6 EFFLUENT DOCUMENTATION DURING SUBSEQUENT REENTRY DRILLING

Below a depth of 4,700 feet, which was reached within four days of the start of drilling on September 22, 1973, the radiological program outlined above 
was continued and augmented as described below.

5.6.1 A qualified radiological protection monitor, equipped with a portable beta-gamma survey meter and a portable explosimeter, was on duty on or near the drill rig at all times. When tripping out of the hole, each stand of pipe was monitored as the joint was broken.

5.6.2 The collection and analysis schedule for mud, water, air, and drill cutting samples was increased from once per day to once per 8 -hour shift.

5.6.3 Mid, drill cuttings, and waste water were disposed of with no restrictions imposed by radioactivity as long as the re was no detectable fission product activity. The only contaminant found was tritium as moisture in solids and in decontamination water. Tritiated water from decontamination activities was transferred to one of the storage tanks for later injection into the disposal well. A few barrels of tritiated solid waste were accumulated for subsequent disposal in an approved manner.

5.7

EFELUENT DOCUMENTATION DURING PRODUCTION TESTING

During the production testing period, gas produced from the chimney was continuously sampled and monitored by the production test sampling system shown schematically in Figure 22. The on-line system was coupled to the flare line between the separator and the flow-measurement equipment to provide a reasonably isokinetic and homogeneous sample of the gas stream being flared. The production test sampling system dehydrator provided pressure reduction and cooling for complete liquid removal prior to the gas entering the radiation monitoring sections. After radiation measurements were made on the dry gas stream, the gas was released to the atmosphere through a 20 -foot high vent at a rate of several CFM. The shielded gamma scintillation detector was recorded and the alarm set at twice the normal upper level of background readings to alert if any unexpected fission products were in the gas. No such readings above background were obtained. The sample line was heated with heat tapes and maintained the oil and moisture in vapor form until the gas sample reached the heat exchanger, thus keeping the line from freezing up during unfavorable conditions. The bulk liquids trap dropped out the bulk of the water which was transferred to the contaminated water storage tanks for injection into the disposal well. The integrating flow meter was used to quantify the analyses of the particulate and charcoal samples. The sample manifold, exhaust, and calibration system were so connected that each detector was independent of the operating condition of the other.

During both production test periods, measurements were made as described below. The TRY-KRY system was operated periodically and provided data on the concentrations of ${ }^{85} \mathrm{Kr}$ and ${ }^{37} \mathrm{Ar}$. It was found that the low levels of ${ }^{3} \mathrm{H}$ encountered and the interfering response of the system to the higher levels 


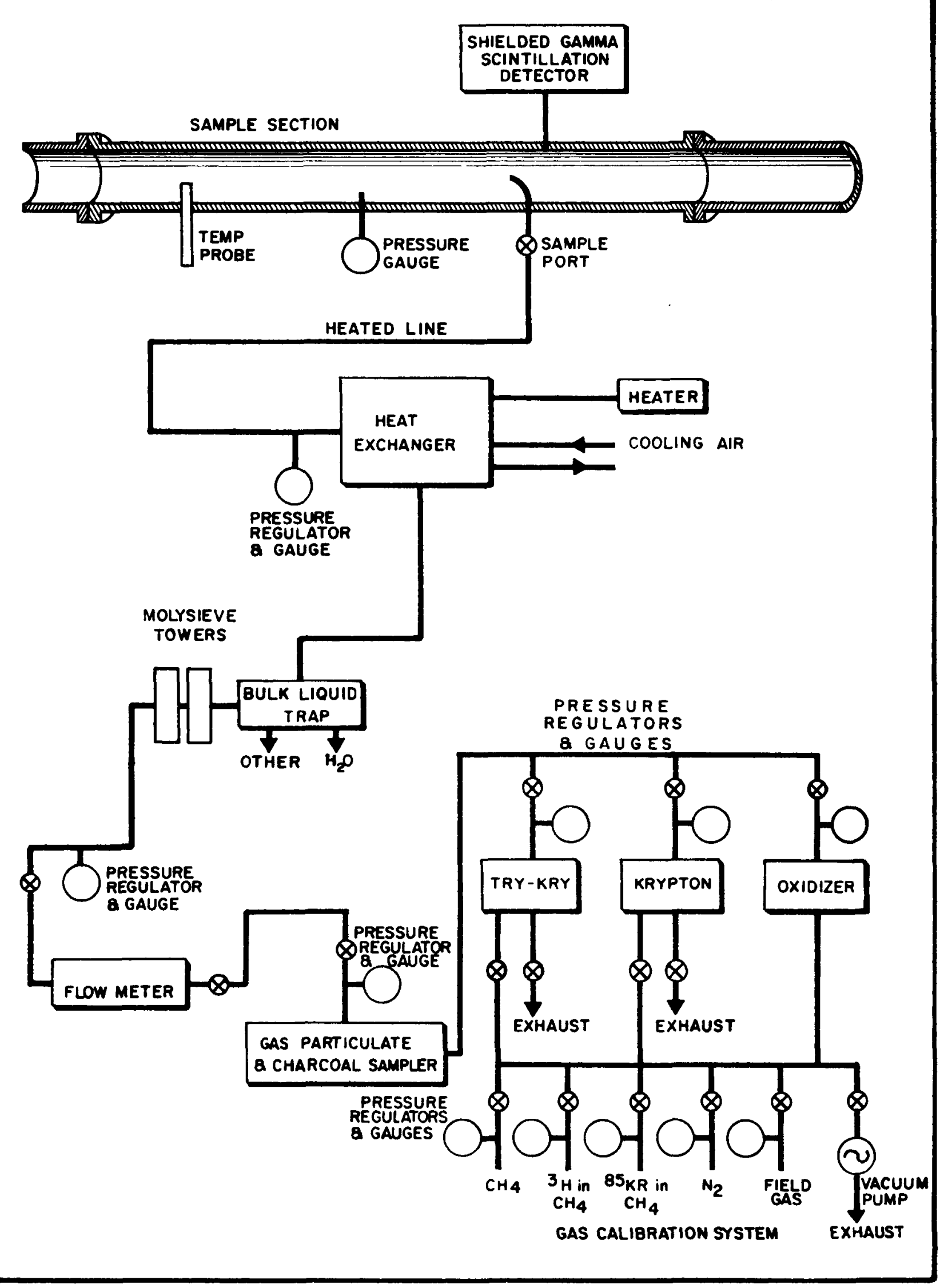

Figure 22. Production test gas sampling system. 
of ${ }^{37}$ Ar precluded the evaluation of ${ }^{3} \mathrm{H}$ concentrations by the TRY-KRY. The krypton chamber was operated and recorded continuously to provide data on $85 \mathrm{Kr}$ concentrations for comparison with the TRY-KRY. The ${ }^{85} \mathrm{Kr}$ calibration gases for both systems were normalized to agree with a calibration sample provided by the Quality Assurance Branch, National Environmental Research Center, U.S. Environmental Protection Agency, Las Vegas, Nevada.

The oxidizer was operated several times daily to provide combustion water samples from the gas. These were counted by liquid scintillation means to provide data on the ${ }^{3} \mathrm{H}$ concentration.

Particulates in the dry conditioned gas were integrated over each production test period and subsequently counted with a sensitive Ge ( $\mathrm{Li}$ ) system in one of EIC's laboratories.

Samples of water were taken from the separator daily and from each water tank after filling. Analyses were made for ${ }^{3} \mathrm{H}$ concentration, by gross beta and alpha counting, and by gamma spectrometry. All data obtained were at background levels except for ${ }^{3} \mathrm{H}$. No samples of hydrocarbon condensates were analyzed, for none was separated during either production test.

A site air particulate and moisture sampling system was operated continuously during production testing. Particulate filters were analyzed by gross beta and alpha counting. Both the particulate and charcoal filters were analyzed by gamma spectrometry. The air moisture samples were assayed for ${ }^{3} \mathrm{H}_{3}$ by liquid scintillation means. All data were at background levels except for ${ }^{3} \mathrm{H}$.

During both production tests, gas and liquid samples were taken by EIC in containers supplied by LLL and turned over to LLL's representative for shipment.

5.8 SUMMARY OF EFFLUENT DATA

The data obtained in the CER/EIC effluent documentation effort have been reported in detail in References 6 and 7. Data obtained by ILLL in gas sample analyses is included in Reference 7. In summary form, during the two production tests from the upper chimney about 52 curies $(\mathrm{Ci})$ of ${ }^{3} \mathrm{H}, 776 \mathrm{Ci}$ of $85 \mathrm{Kr}$, and $89 \mathrm{Ci}$ of $37 \mathrm{Ar}$ were released to the flare stack, with fractional curie amounts of ${ }^{39} \mathrm{Ar},{ }^{14} \mathrm{C}$, and ${ }^{13} 1 \mathrm{~m}_{\mathrm{Xe}}$. A trace quantity, on the order of $10^{-5} \mathrm{Ci}$, of $203 \mathrm{Hg}$, was released during the second drawdown. ${ }^{203} \mathrm{Hg}$ was not detected during the first drawdown. About $150 \mathrm{Ci}$ of ${ }^{3} \mathrm{H}$ in the produced water were injected into the water disposal well. 


\section{RADIOLOGICAL MONITORING IN THE ENVIRONMENT}

The routine radiological monitoring program for the environment as described in Reference 2 was extended to July 31, 1974, as a result of the decision to drawdown the top chimney the second time. The detailed results of this effort have been reported by EIC in a set of quarterly reports collectively identified as Reference 8. The last three of these reports, covering the period November 1973 to July 1974, relate to the two RB-E-02 production test periods. Summaries of these quarterly reports are included as Appendix $E$ to this report. No elevated levels of radioactivity which were attributable to Project Rio Blanco were observed in this environmental monitoring program.

During the first production testing, the routine radiological monitoring program was augmented in the areas of water, air particulate, and air moisture sampling. Some additional effort was expended in sampling soils, vegetation and milk-cow feed, in bioassays, in external background measurements and opportune precipitation sampling.

During the second production testing and because of the favorable results obtained during the first production test, augmentation of the routine program was limited primarily to water sampling at nearby locations and to precipitation and snow sampling near the flare stack. Some additional effort was expended on air moisture sampling, bioassays, and external radiation measurements in the immediate site vicinity.

The results of the augmented radiological programs were generally consistent with background observations. The only data obtained showing above background were for ${ }^{3} \mathrm{H}$ in some soil and precipitation sampling near the flare stack and in some site air moisture samples. The flare stack area sampling results ranged from not detectable $\left(<2 \mathrm{pCi}^{3} \mathrm{H}\right.$ per $\mathrm{ml}$ liquid) to $102.3 \mathrm{pCi} / \mathrm{ml}$. The site air moisture sampling results ranged from not detectable to 16.4 $\mathrm{pCi} / \mathrm{ml}$. These programs are reported in greater detail in Reference 6 .

The paucity of positive data in the environmental radiological monitoring programs precludes meaningful calculation of dose to persons in the environment and confirms the predictions of the environmental statement ${ }^{(9)}$ that the dose would be so low as to be unmeasurable. The ${ }^{90} \mathrm{Sr}$ data and gamma scan of air particulate, water, and vegetation confirm that no measurable quantities of long-lived particulate fission products were added to the environment. The TLD data are in the same range as those previously reported in the reports collectively identified as Reference 8. It is concluded that the environmental impact of the releases of radioactivity to the atmosphere in the flaring of gas from the RB-E-01 well is not measurable above the sensitivities stated in References 6 and 8. Therefore, it is estimated that the potential radiation dose equivalents, considering the sensitivities of the analytical procedures, were a very small fraction of the Radiation Protection Standards of AEC Manual Chapter 0524. 
0

0

$-50-$ 


\author{
APPENDIX A \\ DAILY DRILLING REPORTS \\ RB-E-01
}

\title{
1973
}

September 22 - Rigging and testing. Rig personnel available on September 21, 1973: one driller and two men. Unable to start on $12 \mathrm{hr}$ shifts. Lost two men each on two crews. Total available now: two drillers and four men. Changed out liner on mud pump to 5 -inch. Drilled rat hole. KB $22 \mathrm{ft}$ above ground level. All depths KB.

September 23 - Picked up 3-1/2-inch drill pipe. Tested mud system to 2000 psig. Tested okay. Held operations meeting with drilling crews. Ran Servco 6-1/8-inch Economill, 5-inch Dynadrill, two Gray inside BOP's, one 5-inch drill collar, Otis drill pipe plug nipple (Type "Q"), five additional 5 -inch drill collars, and Otis drill pipe plug nipple (Type "N"). Ran in hole in 3-1/2inch I. F. drill pipe to $2500 \mathrm{ft} \mathrm{KB}$. Circulated and set drilling instruments. Closed pipe rams on 3-1/2-inch drill pipe. Left well shut in overnight. Have two drillers and five men.

September 24 - Drilling cement at $3530 \mathrm{ft} \mathrm{KB}$. 6-1/8-inch hole. (Prog. $733 \mathrm{ft}$ ) Ran mill to $2797 \mathrm{ft}$ and tagged top of cement. Drilled cement from $2797 \mathrm{ft}$ to $3530 \mathrm{ft} \mathrm{KB}$. Circulated hole clean. Pulled two stands. Closed in well. SDON. Crew remaining: two drillers and six men. Bit \#l - Servco Economill - $2797 \mathrm{ft}$ to $3530 \mathrm{ft}-733 \mathrm{ft}$ in $9 \mathrm{hrs}$. Six 5 -inch drill collars; WOB 6000 1b; 250-300 RPM with Dynadrill; drill pipe tool jts.: 3-1/2-inch I. F.; drill collar tool jts.: 3-1/2-inch I. F.; 5-inch pump; 50 SPM; 250-300 GPM; PP 800-1000 lb. Drilling with water. Operating $12 \mathrm{hrs}$. /day.

September 25 - Drilling cement at $4365 \mathrm{ft}$. (Prog. $835 \mathrm{ft}$ ) 6-1/8-inch bit. Drilled cement from $3530 \mathrm{ft} \mathrm{KB}$ to $4365 \mathrm{ft} \mathrm{KB}$. Circulated hole $30 \mathrm{~min}$. Pulled two stands drill pipe. Closed in well. SDON. Crew status: two drillers and eight men. Bit \#1 - Servco Economill - $2797 \mathrm{ft}$ to $4365 \mathrm{ft}$ - $1568 \mathrm{ft}$ in 19 hrs. Six 5-inch drill collars; WOB $6000 \mathrm{lb}$; $250-300$ RPM; drill pipe tool jts.: 3-1/2-inch I. F.; drill collar tool jts.: 3-1/2-inch I. F. ; 5-inch pump; 50 SPM; 250-300 GPM; PP 800-1000 lb. Drilling with water. Operating $12 \mathrm{hrs} / \mathrm{day}$.

September 26 - Testing BOP's and mixing mud. Depth $4700 \mathrm{ft} \mathrm{KB}$. (Prog. $335 \mathrm{ft}$ ) 6-1/8-inch hole. Drilled cement from $4365 \mathrm{ft}$ to $4700 \mathrm{ft} \mathrm{KB}$. Circulated well 30 minutes. Displaced water with mud. Pulled out of hole. Laid down Dynadrill \# 1 and mill. Dumped water from circulating pits. Started cleaning pits and testing BOP stack. SDON. Crew: two drillers and eight men. Bit \# 1 - Servco Economill - $2797 \mathrm{ft}$ to $4700 \mathrm{ft}-1903 \mathrm{ft}$ in $24 \mathrm{hrs}$. Six 5 -inch drill collars; WOB $6000 \mathrm{lb}$; 250-300 RPM; drill pipe tool jts. 3-1/2-inch I. F.; drill collar tool jts. - 3-1/2-inch I. F.; 5-inch pump; 50 SPM; 250-300 GPM: PP 800-1000 1b. Drilling with water. Operating 12 hrs./day. 
September 27 - Drilling cement at $4762 \mathrm{ft}$. (Prog. $73 \mathrm{ft}$ ) 6-1/8-inch hole. Finished pressure testing BOP to 3000 psi. Operated D.W.C. and Otis equipment. Checked okay. Mixed mud. Strapped in to $4691 \mathrm{ft}$. Corrected Geolograph to $4691 \mathrm{ft}$. Have 3 drillers and 12 men. Started $24 \mathrm{hr}$. operation September 27, 1973. No radiation or gas detected to date. Bit \#2 - Servco $469 \mathrm{l} \mathrm{ft}$ to $4762 \mathrm{ft}$. Six 5 -inch drill collars; WOB $6000 \mathrm{lb} ; 250-300 \mathrm{RPM}$; drill pipe tool jts. - 3-1/2-inch I. F.; drill collar tool jts. - 3-1/2-inch I. F.; 5 -inch pump; 50 SPM; 250-300 GPM; PP 800-1000 lb. BHA: Servco mill, 5 -inch Dynadrill, 1 Gray inside BOP, 5-inch drill collar, 1 Gray BOP, Otis "Q" nipple, Five 5-inch drill collars, and 1 Otis nipple. Drilling with low lime mud - Wt. $9.0 \mathrm{lb}$; Vis. 44. Operating $12 \mathrm{hrs}$. - daylight.

September 28 - Tripping for tapered mill. (Prog. $723 \mathrm{ft}$ ) Depth $5485 \mathrm{ft}$ cement and casing. 6-1/8-inch hole. Operating 24 hrs. Drilled cement from $4762 \mathrm{ft}$ to $5194 \mathrm{ft}$. Circulated out gel-water solution to $535 \mathrm{l} \mathrm{ft}$. Hit iron. Milled $2 \mathrm{ft}$ and washed to $5452 \mathrm{ft}$. Milled iron $2 \mathrm{ft}$. Washed to $5484 \mathrm{ft}$. Milling on iron. Milled to $5485 \mathrm{ft}$. Coming out of hole for tapered mill. Will lay down Dynadrill. No radiation or gas shows. Bit \#2 - Servco - 4691 $\mathrm{ft}$ to $5485 \mathrm{ft}$. Six 5 -inch drill collars; WOB $6000 \mathrm{lb} ; 250-300 \mathrm{RPM} ; 3-1 / 2$ inch I. F. drill pipe tool jts.; 3-1/2-inch I. F. drill collar tool jts.; 5-inch pump; 50 SPM; 250-300 GPM; PP 800-1000 lb; BHA: Servco mill, 5-inch Dynadrill, 1 Gray inside BOP, 5-inch drill collar, 1 Gray BOP, Otis "Q" nipple, five 5 -inch drill collars, and 1 Otis nipple. Low lime mud - Wt. 8. 6 lb; Vis. 40; WL $6 \mathrm{cc}$; FC 2/32; pH 12; PV 52; Yp 32.

September 29 - Trip for mill \#5. Depth $5508 \mathrm{ft}$ - cement and iron. (Prog. $23 \mathrm{ft})$ 6-1/8-inch hole. Mill \#4 milled on iron 5494-5498 ft. Washed down to $5506 \mathrm{ft}$ and milled on iron 5506-08 ft. Pulled out of hole. Shows wear around outside and around center of mill. Mill \#3 shows wear around shoulders of 6-1/8-inch O.D. section and extreme wear on bottom. All center cut is gone over an O. D. of approximately 2-1/2-inch. Water course out bottom was nearly sealed off.

September 30 - Trip in with mill \#6. Depth $5549 \mathrm{ft}$ - metal. (Prog. $41 \mathrm{ft}$ ) 6-1/8-inch hole. Low lime mud - Wt. 9.0 lb.

October 1 - Reaming tight spot in casing. Depth $5554 \mathrm{ft}$ - formation - metal. (Prog. $5 \mathrm{ft}$ ) 6-1/8-inch hole. Reamed with mill \#6 back to bottom. Apparently went outside of 10-3/4-inch casing at $5551 \mathrm{ft}$. Started getting some shale back to surface. Made trip for mill \#7. Went in hole. Found tight spot 5506-5510 ft. Reamed through tight spot several times. Still pulled tight. Pulled $140,000 \mathrm{lb}$ to get loose. Worked through spot and went to $5522 \mathrm{ft}$. Milled for 2 hrs. Made $1 \mathrm{ft}$. Pulled out of hole. Ran tapered mill and started reaming up hole at $5350 \mathrm{ft}$. Went through tight spot once. Reamed back again. Apparently went off other side. Could not make any hole. Picked up and reamed through tight spot. Okay. Went to $5450 \mathrm{ft}$ and reamed through tight spot. Went to $5486 \mathrm{ft}$. While reaming, got stuck. Pulled free with $175,000 \mathrm{lb}$. 
No radiation or gas to surface. Six 5-inch drill collars; WOB $4000-8000 \mathrm{lb}$ 40-70 RPM; 5-inch pump; BHA: mill, Baker float, 1 drill collar, Gray inside BOP, Otis plug nipple Type " $Q$ ", five 5 -inch drill collars, Otis plug nipple Type "N". Low lime mud - Wt. 9.0 Ib; Vis. 38.

October 2 - Logging with Schlumberger. Depth $5554 \mathrm{ft}$. (Prog. $0 \mathrm{ft}$ ) Circulated hole at $5430 \mathrm{ft}$ for $1 \mathrm{hr}$. Pulled out of hole. Inspected drill collars and sub. Found cracked pin on Baker float sub. Laid down sub. Ran Baker 7inch casing scraper to $5360 \mathrm{ft} \mathrm{KB}$. Pulled out of hole. Rigged up Schlumberger to run Caliper and Collar Locator. Prep. to set Baker Model "N" bridge plug in interval 5300-5350 ft and set whipstock for alternate reentry plan.

Mill \#8 - Acme tapered - reaming. Six 5-inch drill collars; 5-inch pump; BHA: same as October 1, 1973. Low lime mud - Wt. 9.0 1b; Vis. 40.

October 3 - Picking up whipstock. PBTD $5322 \mathrm{ft.} \mathrm{Ran} \mathrm{Schlumberger} \mathrm{Casing}$ Caliper and Collar Locator Log from $5400 \mathrm{ft}$ to $2500 \mathrm{ft} \mathrm{KB}$. Set Baker Model "N" drillable bridge plug on wireline at $5322 \mathrm{ft} \mathrm{KB.} \mathrm{Tested} \mathrm{plug} \mathrm{and} \mathrm{casing}$ below blind rams to 1000 psi surface pressure. Tested BOP units to 3000 psi. Held okay. Ran 6-1/4-inch O.D. window mill to $5322 \mathrm{ft} \mathrm{KB}$. Pulled out of hole. Prep. to pick up Bowen whipstock.

October 4 - PBTD $5322 \mathrm{ft}$. 6-1/4-inch hole. Oriented S 10 $0^{\circ} \mathrm{W}, 4^{\circ}$ taper on whipstock. Top of tapered portion $5303 \mathrm{ft} \mathrm{KB}$. Mill \#9 - milled 5304$5307 \mathrm{ft}$ in $7 \mathrm{hrs}$. Mill \#l0 milled 5307-5309 ft in $8 \mathrm{hrs.} \mathrm{Six} \mathrm{5-inch} \mathrm{drill}$ collars; WOB 4,000-8,000 lb; 40 RPM; 5-inch pump; BHA: mill, 1 drill collar, Otis " $Q$ " plug nipple, 5 drill collars, and Otis Type "N" plug nipple Low lime mud - Wt. 9.0 lb; Vis. 40.

October 5 - Trip into hole with Bit \#13. PBTD $5316 \mathrm{ft}$. On Bit \#11, got to formation. Pulled and ran bit \#12 with 3-pt. roller reamer to dress window. Could not make hole in formation. Ran Reed 6-1/8-inch bit with 3-pt. roller reamer. Plan to make $50 \mathrm{ft}$ to $100 \mathrm{ft}$, run survey, pull out of hole and lay down 3-pt. reamer before drilling ahead. Bit \#10-6-1/4-inch finishing mill - 5307-5312 ft in $10 \mathrm{hrs}$. Bit \#1l - 6-1/4-inch finishing mill - 5312-5316 $\mathrm{ft}-6-1 / 2 \mathrm{hrs}$. Bit \#12-6-1/4-inch finishing mill - $5316 \mathrm{ft}$ - no progress 1-1/4 hrs. Bit \#13 in hole. Six 5-inch drill collars; 5 -inch pump; BHA: 6-1/8-inch bit, 3-pt. roller reamer, Gray inside BOP, one 5-inch drill collar, Otis plug nipple Type " $Q$ ", five 5 -inch drill collars, and Otis plug nipple Type "N". Low lime mud - WT. $8.8 \mathrm{lb}$; Vis. 40 .

October 6 - Drilling shale at $5356 \mathrm{ft}$. 6-1/8-inch hole. Bit \#13 - Reed Y31R $0 \mathrm{ft}$ in $2 \mathrm{hrs}$. Bit \# 14 - flat bottom - 6-1/4-inch - 5316-5329 ft - $13 \mathrm{ft}$ in 7 hrs. Bit \#15 - Reed Y3IR - in hole. Bit \#14 was bald when pulled out of hole - badly out of gauge. Dev.: $3^{\circ}$ at $5328 \mathrm{ft}$.

October 7 - Trip for Bit \#17. Depth $5429 \mathrm{ft}$ - sand and shale. Made $73 \mathrm{ft}$. 6-1/8-inch hole. Bit \#15 - Reed Y31R - $5329 \mathrm{ft}$ to $5371 \mathrm{ft}$. Bit \#16 - HTC 
OWC-J $-5371 \mathrm{ft}$ to $5429 \mathrm{ft}$. Dev.: $2-3 / 4^{\circ}$ at $5361 \mathrm{ft} ; 2-1 / 2^{\circ}$ at $5419 \mathrm{ft}$.

October 8 - Drilling sand and shale at $5580 \mathrm{ft}$ in sidetracked hole. Made 151 ft. Bit \#17 - Williams dia. - in hole. Six 5-inch drill collars; WOB 8,00012, $000 \mathrm{lb} ; 300 \mathrm{RPM}$; 5 -inch pump; BHA: dia. bit, Dynadrill, change-over sub, float sub, Gray inside BOP, one 5 -inch drill collar, Gray inside BOP. Otis " $Q$ " nipple, five 5 -inch drill collars, Otis " $N$ " nipple and 3-1/2-inch drill pipe. No gas or radiation to surface. Low lime mud - Wt. $8.9 \mathrm{lb}$, Vis. 48 .

October 9 - Mixing mud. Depth $5614 \mathrm{ft}$. 6-1/8-inch hole. Made $34 \mathrm{ft}$. Dev. : $2^{\circ}$ at $5510 \mathrm{ft}$. Tripped at $5585 \mathrm{ft}$ to change out Dynadrill. Drilled ahead with 6-1/8-inch bit and new Dynadrill. Lost partial returns at $5597 \mathrm{ft}$. Drilled to $5602 \mathrm{ft}$. Healed up lost circulation zone. Pumped in mud at rate of $10 \mathrm{BPM}$ with no returns. Pumped down annulus and drill pipe. Could not get returns. Lost $400 \mathrm{bbls.} \mathrm{mud.} \mathrm{Pulled} 4$ stands to get Dynadrill inside 7 -inch casing. Pumped 200 bbls. additional water. No returns. No gas to surface after $6 \mathrm{hrs}$. No radioactivity to surface. Bit \#17 - Williams - dia. - 5429-5614 ft - $185 \mathrm{ft}$ in $26 \mathrm{hrs.} \mathrm{5-inch} \mathrm{pump.} \mathrm{Low} \mathrm{lime} \mathrm{mud} \mathrm{-} \mathrm{Wt.} 8.9 \mathrm{lb}$. (Appears that lost circulation zone is caused from roof sag above chimney without communication with chimney. Intend to mix viscous mud, pull Dynadrill, run conventional bit and drill ahead without returns, if necessary.)

October 10 - Drilling sand and shale at $5620 \mathrm{ft}$. Drilled $6 \mathrm{ft}$, reamed $280 \mathrm{ft}$. 6-1/8-inch hole. Mixed mud. Pulled out of hole and laid down Dynadrill. Ran bit \#18. Had problems getting through whipstocked window. Established circulation. Cleaned shale bridges in 6-1/8-inch hole from $5334 \mathrm{ft}$ to $5614 \mathrm{ft}$. Had to overhaul power swivel. Swivel motor seals went out. Lost $500 \mathrm{bbls}$. mud while reaming hole from $5334 \mathrm{ft}$ to $5614 \mathrm{ft}$ and while drilling to $5620 \mathrm{ft}$. Have Halliburton on location mixing mud. Bit \#18-HTC OWV reg. - 5614 $\mathrm{ft}$ to $5620 \mathrm{ft}$. Six 5-inch drill collars; WOB 2,000-6,000 1b; 50-70 RPM; BHA: bit, bit sub, Baker float sub, Gray inside BOP, one 5-inch drill collar, Gray inside BOP, Otis nipple Type " $Q$ ", five 5-inch drill collars, and Otis nipple, Type "N", Gel-Chem - Wt. 9.0 lb; Vis. 65-75; WL 11.2 cc; FC 2/32.

October 11 - Drilling shale at $5620 \mathrm{ft}$ (corrected). Made $8 \mathrm{ft}$. 6-1/8-inch hole. Pulled out of hole. Laid down power swivel. Not enough power to drill. Laid down rotating head. Installed Hydril. Tested BOP's. Strapped pipe out and in. Corrected depth $5620 \mathrm{ft} \mathrm{KB}$ at 8 a. m. October 11, 1973. Drilling ahead with partial circulation. Halliburton mixing mud. Lost approximately $250 \mathrm{bbls}$. mud in last $24 \mathrm{hrs}$. Using LCM to partially heal lost circulation zone. No gas or radioactivity to surface. Bit \#18- HTC OWV - 5601$5612 \mathrm{ft}-11 \mathrm{ft}$ in $12 \mathrm{hrs}$. - drlg. and rmg. - slightly out-of-gauge. Bit \#19 in hole. 5-inch pump. BHA: bit, bit sub, Baker float sub, Gray inside BOP, one 5-inch drill collar, Gray inside BOP, Otis nipple Type "Q", five 5 -inch drill collars, and Otis nipple, Type "N". Gel-water - Wt. 8.8 lb; Vis. 75 . 
October 12 - Rigging up bottom snubbers. Depth $5706 \mathrm{ft}$ - sand and shale. Made $86 \mathrm{ft}$. 6-1/8-inch hole. Drilled from 5620 to $5633 \mathrm{ft}$ with partial lost circulation. Ran out of mud. Pulled 5 stands to mix more mud and obtain more water. Ran back to bottom. Drilled to $5706 \mathrm{ft} \mathrm{KB}$ with no returns. Ran out of mud. Lost 4000 bbls. mud while drilling from $5620 \mathrm{ft}$ to $5706 \mathrm{ft}$. Pulled 10 stands into derrick. Ran 90 jts. 3-1/2-inch drill pipe. Started rigging up bottom snubbers.

Note: Had pressure buildup of gas to surface while mixing mud at $5671 \mathrm{ft}$. Pressure up to 320 psi. Sample of gas indicated Krypton-85 and Tritium. Pumped $150 \mathrm{bbls}$. mud down annulus to kill well. Bled remaining gas to flare stack through D.W.C. Bit \#19- HTC OWV - 5612-5706 ft - $94 \mathrm{ft}$ in $8 \mathrm{hrs}$. Still in hole. Six 5-inch drill collars; WOB 2,000-8,000 lb; 50-90 RPM; BHA: bit, bit sub, Baker float sub, Gray inside BOP, one 5-inch drill collar, Gray inside BOP, Otis nipple Type "Q", five 5-inch drill collars, and Otis nipple, Type "N". Gel-water - Wt. $8.8 \mathrm{lb}$; Vis. 75.

October 13 - Running in with wireline to set packer. Finished rigging up snubbing equipment. Came out of hole laying down 3-1/2-inch drill pipe. Laid down all 3-1/2-inch drill pipe. Stood back 6 drill collars. Did not need to snub out of hole. Pumped in mud at slow rate while coming out of hole. Shut blind rams. Rigged up Birdwell and 7-inch lubricator to $r$ un packer and bottom hole assembly. Had 750 psig gas pressure on casing at 8:00 a. m. No radioactivity contamination.

October 14 - Rigging up to pull Otis plugs. Depth of packer $5260 \mathrm{ft} \mathrm{KB}$. Pumped in $300 \mathrm{bbls.} \mathrm{fresh} \mathrm{water} \mathrm{down} \mathrm{the} \mathrm{casing.} 0 \mathrm{lb}$ at surface. Equalized above and below blind rams. Opened rams. Ran packer in hole on wireline. Set packer at $5260 \mathrm{ft} \mathrm{KB}$. Bottom hole assembly from bottom up is bull plug, 8-inch screen jt., Otis "N" plug with 2-inch SN plug installed, 2 ft 2-3/8-inch tubing nipple, tail pipe adapter, Otis Permatrieve PW wireline set packer. Rigged down Birdwell. Filled hole with water. Packer held okay. Laid down six 5-inch drill collars. Changed bottom 3-1/2-inch and 5-inch BOP rams to 2-7/8-inch rubing rams. Ran $168 \mathrm{jts}$. 2-7/8-inch EUE tubing and one $4 \mathrm{ft}$ sub to the tubing hanger with Otis equipment on bottom of the tubing as follows: Mule shoe guide, "J" latch assembly without locking bar, "N" nipple with 2-1/2-inch PXN plugs installed, and tubing centralizer. Landed tubing at $5229 \mathrm{ft} \mathrm{KB}$. OCT hanger locked into wellhead. Landing nipple to hanger made up to $700 \mathrm{ft}$. $-1 \mathrm{~b}$ torque. Remainder of string made up to $1300 \mathrm{ft}$. $-1 \mathrm{~b}$ torque. Used 2-7/8-inch tubing nipples from hanger to rig floor. Installed 2-7/8-inch full bore tubing valve. Pressure tested valve to 3000 psi before installation. Pressure tested between tubing hanger and BOP 2-7/8-inch tubing rams to $3000 \mathrm{lb}$. Held okay. Started rigging up Otis equipment to pull plugs. 
October 15 - Well SI. Building up pressure. Rigged up Otis equipment to pull tubing plugs. Surface wireline equipment broke down. Called out Wireline truck. Pulled Otis PXN plug from bottom of tubing. Attempted to pull Otis SN plug from packer. Sheared off of plug twice. Put 250 psig Nitrogen pressure on annulus and unloaded water up the tubing. Bled off Nitrogen pressure. Ran retrieving tools with Wireline hydraulic jars. Pulled SN plug from packer at 10:30 p.m. October 14, 1973. No radiation on tools or plug. Surface CP at 6 a. m. October 15, 1973 was 300 psig.

October 16 - Well shut in. Pressure at 8 a.m. October 16, 1973400 psig.

October 17 - Preparing to kill well and pull tubing. Pressured annulus with $\mathrm{N}_{2}$ with 2700 psig from 400 psig. Started at $1000 \mathrm{cu}$. ft. $/$ min., increased to 2000 cu. ft. / min. Pressure increased to $2500 \mathrm{psig}$ in $30 \mathrm{~min}$. Decreased rate gradually to $1000 \mathrm{cu}$. ft. / min. Pressure increased to $2700 \mathrm{psig}$. Estimated water displaced through screen on packer at $50 \mathrm{bbls}$. Shut down $\mathrm{N}_{2}$ injection. Flowed well to flare stack through D. W. C. unit. Well loaded up and died twice. Injected additional $\mathrm{N}_{2}$ into annulus to clean water out of hole. Rec. $100 \mathrm{BW}$ to storage tank. At end of clean up, well was flowing $510 \mathrm{MCF} / \mathrm{D}$ at an apparent stabilized CP of 500 psig with 200 psig on the D. W. C. unit. Radiation level at stabilized rate was approximately $400 \mathrm{pCi} / \mathrm{cc}$ of Krypton 85 . Radiation level of produced water was background. Total $\mathrm{N}_{2}$ injection was $170,000 \mathrm{cu}$. ft. Total flow back 135,000 cu. ft. Well was SI 7:15 p. m. October 16, 1973. Pressure at $7: 15$ p. m. October 16, 1973 was 500 psig. Pressure at 10 p. m. October 16, 1973 was 1075 psig; pressure at 7 a. m. October 17, 1973 was 1650 psig. Preparing to blow well down, kill with mud, and pull packer.

October 18 - Pulling tubing and packer from well. Blew well down to flare stack through D.W.C. unit. CP at start of blow down 1650 psig. Went down to 450 psig. Killed well with mud. Screen joint appeared to be partially plugged. Well would pressure up while trying to pump down hole. Pumped water down tubing to wash contamination out of tubing. Ran in with wireline tools to position packer retrieving sleeve. Made several trips to position sleeve. Latched onto packer with tubing. Released packer. Could not pump past packer down the annulus. While pulling packer, started swabbing the hole. Pumping down tubing out the bottom of the packer around the outside of the screen joint every 15 stands to keep well killed. Plan to pick up bit, clean out hole, and drill a few feet deeper.

October 19 -Drilling and washing back to bottom. Depth $5633 \mathrm{ft}$. 6-1/8-inch hole. Pulled packer and screen jt. out of hole. Screen jt. plugged with fine cuttings. Decontaminated packer and sent in for redressing. Screen jt. will have to remain on location until decontaminated. Tripped into hole with 6-1/8inch bit to clean out and drill ahead. Hit bridges from $5560 \mathrm{ft} \mathrm{KB}$ down. Present depth $5633 \mathrm{ft}$. TD of hole $5706 \mathrm{ft}$. Lost returns at $5565 \mathrm{ft} \mathrm{KB}$. Gained partial returns at $5575 \mathrm{ft}$. Lost total of $750 \mathrm{bbls}$. in the last $24 \mathrm{hrs}$. Circulating system is contaminated. Radioactivity level $44 \mathrm{pCi} / \mathrm{ml}$. Bit \#20 - HTC OWV - drilled and washed - $6 \mathrm{hrs.} \mathrm{-} \mathrm{still} \mathrm{in} \mathrm{hole.} \mathrm{Six} \mathrm{5-inch} \mathrm{drill} \mathrm{collars;}$ 
5 -inch pump; BHA: bit, bit sub, Baker float sub, Gray inside BOP, one 5inch drill collar, Gray inside BOP, Otis " $Q$ " nipple, 5 drill collars, and Otis "N" nipple. Gel-water - Wt. $8.8 \mathrm{lb}$; Vis. 45.

October 20 - Laying down 3-1/2-inch drill pipe. PBTD $5634 \mathrm{ft}$. Washed to bottom at $5706 \mathrm{ft}$. Drilled to $5745 \mathrm{ft}$. No circulation. Had several good drilling breaks. Pulled out of hole. Strapped out at $5745 \mathrm{ft} \mathrm{KB}$. Ran $16 \mathrm{jts}$. 5-inch O.D., $15 \mathrm{lb}$, JCS hydril flush jt with Brown Type "V" shoe and 2 valve float collars just above shoe. Ran Brown "Hyflo" H.D. 5-inch, 18 lb hanger packer on top of liner. I. D. of hanger 4-9/32-inch. I. D. of liner 4-3/8-inch. Length of liner shoe, float collar and hanger $507 \mathrm{ft}$. "Baker-Lok'd" all jts. Bottom of liner $5735 \mathrm{ft} \mathrm{KB}$ and tagged fill. Set liner with bottom at $5734 \mathrm{ft} \mathrm{KB}$. Top of hanger $5227 \mathrm{ft} \mathrm{KB}$. Starting out of hole, laying down drill pipe. Line $r$ is overlapped $76 \mathrm{ft}$ into 7 -inch casing. Bit \#20 - HTC OWV reg. Washed at $5706 \mathrm{ft}$. Drilled from $5706 \mathrm{ft}$ to $5745 \mathrm{ft}-39 \mathrm{ft}$ in $2 \mathrm{hrs}$. BHA: same as October 19, 1973. Gel-water - Wt. 8. 9 lb; Vis. 60-70.

October 21 - Waiting on Birdwell. Finished laying down 3-1/2-inch drill pipe and 5 -inch drill collars. Ran 167 jts. 2-7/8-inch tubing. Tubing string from bottom up: mule shoe, $4 \mathrm{ft}$ pup with centralizer, Otis "XN" nipple, 167 jts 2-7/8-inch tubing, $4 \mathrm{ft}$ pup, and tubing hanger. Bottom of tubing at $5200 \mathrm{ft} \mathrm{KB}$. Waiting on Birdwell.

October 22 - Logging. Birdwell attempted to run GR survey. Tool quit working after getting to bottom. Came out of hole. Ran Temperature Survey. Temperature went to $270^{\circ} \mathrm{F}$. at $5565 \mathrm{ft}$, then failed. Pulled temperature tool. Repaired and reran. Maximum temperature on survey $286^{\circ} \mathrm{F}$. Appeared to have two peaks: $286^{\circ}$ at $5630 \mathrm{ft}$ and $283^{\circ}$ at $5665 \mathrm{ft}$. Called out Schlumberger with high temperature line temperature survey tool and GRN tool. Schlumberger temperature survey indicated single peak - much broader with peak of $265^{\circ} \mathrm{F}$. at $5675 \mathrm{ft}$. It appears that fluid may still be moving down hole. Pumped in $50 \mathrm{BW}$. Running Temperature Survey to determine hot spots. Will continue survey until hot spots are stabilized. Cleaned out mud tanks and filled with water.

October 23 - Rigging up Halliburton and hauling water. Completed running temperature surveys. Hot areas indicated between $5632 \mathrm{ft} \mathrm{KB}$ and bottom of liner at $5734 \mathrm{ft} \mathrm{KB}$. Gamma Ray Neutron Log did not show definition of chimney or fractured region. Plan to perforate using through-tubing jets. Birdwell perforated with strip gun \#l from $5727 \mathrm{ft}$ to $5702 \mathrm{ft} \mathrm{KB}$ with one 1-11/16inch jet/ft. Total of 25 shots. Pumped $50 \mathrm{BW}$ down annulus. Started in hole with strip gun \#2 to perforate 5702-5677 ft KB. Unable to get below liner top. Started out of hole to check strip gun. Well started blowing in through cable head pack-off. Could not completely shut off stuffing box control head. Pulled gun into lubricator. Shut tubing master valve. Released Birdwell truck with 5/16-inch line. Ordered out unit with 3/16-inch line and a grease injection control head to finish perforating. Started rigging up Halliburton to pump down tubing while perforating. 
October 24 - Perforating with Birdwell. Changed out tubing floor valves. Have two new floor valves on tubing. Keeping well killed by pumping water down annulus and tubing periodically. Rigging up Birdwell perforating truck with grease injection system and 3/16-inch line. Perforated liner 5702-5677 ft KB with 2 JSPF using 1-11/16-inch ceramic jets. Preparing to run in and perforate $5677-5652 \mathrm{ft} \mathrm{KB}$.

October 25 - Well shut in to build up pressure. Perforated liner from $5677 \mathrm{ft}$ to $5652 \mathrm{ft} \mathrm{KB}$ with $2 \mathrm{JSPF}$ using 1-11/16-inch ceramic jets. Perforated 5652$5627 \mathrm{ft} \mathrm{KB}$ with $1 \mathrm{JSPF}$. Rigged down Birdwell. Finished perforating at 12:15 p. m. October 24, 1973. Casing pressure as follows:

\section{$\underline{\text { Time }}$}

$10 / 24 / 73$

$$
\begin{aligned}
& \text { 1:15 p. m. } \\
& \text { 2:15 p. m. } \\
& \text { 3:00 p. m. } \\
& \text { 5:00 p. m. } \\
& \text { 7:00 p. m. } \\
& \text { 9:00 p. m. } \\
& \text { 11:00 p. m. } \\
& \text { 12 midnight } \\
& \text { 10/25/73 } \\
& \text { 2:00 a. m. } \\
& \text { 4:00 a. m. } \\
& \text { 6:00 a.m. } \\
& \text { 7:30 a.m. }
\end{aligned}
$$

$\underline{C P}$

$$
125
$$

260

385

700

960

1250

1450

1525

1510

1525

1510

1525

Plan to flow well this a.m.

October 26 - Waiting on O.C. T. representative. Flowed well through D. W. C. unit for $1 \mathrm{hr}$. $45 \mathrm{~min}$. Initial CP $1525 \mathrm{psig}$, final CP $1600 \mathrm{psig}$. Initial rate $5110 \mathrm{MCF} / \mathrm{D}$. Final rate $5816 \mathrm{MCF} / \mathrm{D}$. Avg. rate $5480 \mathrm{MCF} / \mathrm{D}$. Initial specific gravity 1.084, final specific gravity 1.127. All free liquids produced stored in $400-\mathrm{bbl}$. tank. Total contaminated liquids produced $47 \mathrm{bbls}$. Stored in $400 \mathrm{-bbl}$. tank for injection later. Cumulative gas produced $399 \mathrm{MCF} . \mathrm{H}_{2} \mathrm{~S}$ in gas monitored at $300 \mathrm{ppm}$. Shut down flow after $1 \mathrm{hr} .45 \mathrm{~min}$. Pumped $30,000 \mathrm{SCF} \mathrm{N}_{2}$ down tubing. Pumped 150,000 SCF $\mathrm{N}_{2}$ down annulus. Rigged up Otis and ran Otis "XN" plug in nipple at $5196 \mathrm{ft} \mathrm{KB}$. Bled TP to $900 \mathrm{psig.}$ CP 1700 psig. Plug held okay. Ran Otis "DB collar latch plug to $212 \mathrm{ft} \mathrm{KB}$ and set. Bled off pressure inside of tubing above plug to 0 psig. Held okay. Attempted to bleed of pressure above tubing hanger and lower set of 2-7/8inch pipe rams. Would not bleed off. Called out O.C.T. representative. To arrive on location at 9 a. $\mathrm{m}$. Suspect hanger compression ring problem. 
October 27 - Rigging down rental equipment. Pressured between tubing hanger and pipe rams on BOP several times to 3000 psi. Bled back. Finally got hanger seal to hold. Checked tubing plugs. Holding okay. Opened pipe rams and Hydril. Backed out tubing from top of hanger. Closed blind rams. Removed all BOP's except blinds. Found pressure between blinds and tubing hanger. Bled off. Found small leak around outside of hanger from the annulus. Removed blinds. Installed master valve and tubing head bonnet flange. Pressure tested valve to bonnet connection to $5000 \mathrm{psi}$. Held okay. Unable to pressure test internal sealing connection from bonnet to valve because of small leak around hanger. No external leaks detected. Started rigging down lines to BOP controls and Otis equipment. Preparing to decontaminate D. W. C. unit.

October 28 - Decontaminating equipment. Decontaminated all rental equipment except for D.W.C. unit. Having to steam out inside of unit using rig boiler.

October 29 - Waiting on trucks to move out rig. Finished decontamination of D.W.C. unit. Released rig at 3 p.m. October 28, 1973. Trucks to tear down and move out rig expected on November 1, 1973.

October 30 - Waiting on trucks for rig move-out. Otis equipment moved out and all other rental equipment except D. W. C. moved off site. D. W. C. waiting on trucks.

October 31 - Waiting on trucks to move out D.W.C. unit. Trucks for rig expected on November 1, 1973. Surface CP on well at 1 p.m. October 30, 1973 - 1740 psig.

November 1 - Waiting on trucks to rig down. Moved out D. W. C. unit.

November 2 - Tearing down and moving rig off location.

November 3 through November 6 - Moving off rig.

November 7 - Finished tearing down and moving off location. 


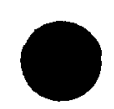

$-60-$ 


\author{
APPENDIX B \\ DAILY DRILLING REPORTS \\ FAWN CREEK GOVERNMENT \#1 WELL \\ REENTRY AND RECOMPLETION - June 18 - September 17, 1973 \\ AND \\ REMEDIAL WORK - November 23 - December 5, 1974
}

1973

June 18 - Moved in Colorado Well Service, Inc. workover rig - rigging up.

June 19 - Rigging up - set water tank and circulating equipment - installed Hydril, double gate BOP - Tested - Ran Hughes Tool Co. 4-3/4-inch bit with four 3-1/8-inch D.C. and 135 joints 2-3/8-inch EUE tubing - tagged top of soft cement at $4364 \mathrm{ft} \mathrm{KB}$. Shut in overnight.

June 20 - Mixed 10 sacks of $\mathrm{KCl}$ with 135 barrels of water. Rigged up to drill. Drilled cement from $4364 \mathrm{ft}$ to $4569 \mathrm{ft} \mathrm{KB}$. Mud pump went down, lost two hours, 4:00 p.m. to 6:00 p.m. Shut down overnight.

June 21 - Drilled cement with $2 \% \mathrm{KCl}$ water from 4569-4845 ft KB. Bit \# 1 cum. 14 rotating hours and $481 \mathrm{ft}$ - weight on bit $6000 \#$ at 70 RPM, pump press 450, reverse circulation. Hart Gleason, LLL, on location.

June 22 - Drilled cement with $2 \% \mathrm{KCl}$ water from 4845-5062 ft KB. Bit \# cum. $21 \mathrm{hrs}$ rotating at $698 \mathrm{ft}$. Wt on bit $6000 \#, 80 \mathrm{RPM}$, pump press 300 psig, reverse circulation. Hart Gleason, LLL, on location. Changed stripper head rubber in a.m. and p. $m$.

June 23 - Drilled cement with $2 \% \mathrm{KCl}$ water from 5062-5247 ft $\mathrm{KB}$. Bit \#l cum. $26-1 / 2 \mathrm{hrs}$ rotating at $883 \mathrm{ft}$. Wt on bit $6000 \#, 80 \mathrm{RPM}$, pump press 300 psig - reverse circulating. Laid down power swivel - removed stripper head. Cleaned cement from flat tank. Started out of hole with string to change bit, elevator latch broke with one-half string out. Shut down overnight for elevator repair. Hart Gleason, LLL, and John Glock, EIC, on location.

June 24 - Filled flat tank with water and added $\mathrm{KCl}$ to $2 \%$ concentration. Repaired elevators. Pulled out of hole with Bit \#1. Good condition. Some bearing wear. Bit \#1 checked for radiation, tested OK. Picked up Bit \#2 HTC 4-3/4-inch WO \#TD047. Went in hole with Bit \#2 and four 3-1/8-inch drill collars on bottom and broke circulation at $12: 30 \mathrm{hrs}$ - drilling at 12:45 hrs. Drilled $26 \mathrm{ft}$ of cement to $5273 \mathrm{ft} \mathrm{KB}$ and service unit motor fuel injection pump broke. Shut down overnight waiting on repairs. Hart Gleason, LLL, and John Glock, EIC, on location. 
June 25 - Down for rig engine repairs from 8:00 a.m. to 11:00 a.m. Drilled cement with $2 \% \mathrm{KCl}$ water from 5273-5435 ft $\mathrm{KB}$. Circulated hole clean. Shut down overnight.

June 26 - Drilled cement from 5435-5524 ft KB. Bit stopped drilling appears to be on junk or metal. Circulated out very fine metal shavings. Have recovered no sand in cuttings. Pulled out of hole. Strap out at $5524 \mathrm{ft}$ KB. Outside 3/8-inch of 4-3/4-inch bit appears to have been drilling on metal - Shut down overnight.

June 27 - Picked up Acme taper mill 4-13/16-inch OD Bowen hydraulic jars and trip in hole. Tagged probable collapsed casing at $5524 \mathrm{ft}$. Rig up drilling equipment and drill 18 inches with mill. Extremely hard returns contained excessive fine shavings of steel and good hard cement. Total rotating hrs with mill - 3-1/2 hrs. Trip out of hole - mill was worn out significantly 18 inches from the bottom up. Evidently casing is collapsed extremely bad. Shut down overnight.

June 28 - Wait on orders from 8:00 a.m. to 3:00 p.m. Shut down overnight.

June 29 - Trip in hole with 4-inch OD Acme tapered mill. Circulated down to $5542 \mathrm{ft}$. Returns contained frac sand and some cement. Power swivel broke down. Pulled three stands of 2-3/8-inch tubing. Shut well in and shut down.

June 30-July 4 - Well shut in - Rig shut down (Standby) - Wait on orders.

July 5 - Pressured 5-1/2-inch casing with water to 575 psig surface pressure. Held $O K$ for 10 minutes. Pulled 4-inch mill - ran 4-3/4-inch OD Impression block to $5525 \mathrm{ft}$ KB. Set down with $10,000 \mathrm{lbs}$ - pulled out of hole. Impression indicates apparent one-half circle of 5-1/2-inch casing looking up. Impression is $1 / 4-$ inch wide around the outside of the block and has bit tooth marks visible on one end. Bore through problem area appears to be $4-1 / 2$ inches. Shut down overnight.

July 6 - Ran Eastman casing roller - Calipered 4-13/16-inch OD - Rotated with $1000 \mathrm{ft}$ lbs torque, 1000-1500 lbs wt on roller at $5525 \mathrm{ft} \mathrm{KB}$ - Tool torques up - Made 2 inches in $4-1 / 2 \mathrm{hrs}$ - Believe most of 2 inches is make up in 2-3/8-inch EUE tubing - Started out of hole laying down 2-3/8-inch tubing - Shut down overnight.

July 7 - Laid down remainder of 2-3/8-inch tubing - Pulled Eastman casing roller - Seven rollers lost downhole off of tool - changed out BOP rams to 2-7/8 inches - Ran 4-inch mill on bottom of string type tapered mill located $7 \mathrm{ft}$ above 4-inch mill - Ran in with jars and four 3-1/8-inch drill collars picked up 57 joints of 2-7/8-inch drill pipe with 3-1/8-inch OD tool joints shut down overnight - waiting on remainder of 2-7/8-inch drill pipe - plan to fish out lost rollers after milling through tight spot - shut down overnight. 
July 8 - Picked up remainder of 2-7/8-inch drill pipe - pipe strap in hole to problem area was $5522 \mathrm{ft} \mathrm{KB} \mathrm{-} \mathrm{Milled} \mathrm{through} \mathrm{damaged} \mathrm{casing} \mathrm{with} \mathrm{two} \mathrm{3000 \#}$ wt, 70 to $80 \mathrm{rpm}$ and $1600 \mathrm{ft}$ lbs torque - Ran 4-inch mill on bottom to depth of $5539 \mathrm{ft} \mathrm{KB}$. 4-7/8-inch mill to depth of $5532 \mathrm{ft} \mathrm{KB}$. Reamed through tight spot several times - did not drag - circulated hole clean - started out of hole for magnet - Shut down overnight.

July 9 - Strapped 2-7/8-inch drill pipe out of hole - Bottom of 4-inch mill $5539 \mathrm{ft} \mathrm{KB}$, depth of 4-7/8-inch mill $5532 \mathrm{ft} \mathrm{KB} \mathrm{-} \mathrm{laid} \mathrm{down} \mathrm{string} \mathrm{mill} \mathrm{-} \mathrm{Ran}$ 4-1/2-inch OD Magnet with jars and 2-7/8-inch drill pipe - set down on bottom at $5539 \mathrm{ft} \mathrm{KB} \mathrm{-} \mathrm{Reverse} \mathrm{circulated} \mathrm{to} 5545 \mathrm{ft} \mathrm{KB}$ - Recovered frac sand - started out of hole - shut down overnight.

July 10 - Pulled out of hole with magnet - recovered four of seven rollers Ran back in hole with 4-1/2-inch OD magnet - set down at $5545 \mathrm{ft} \mathrm{KB} \mathrm{-}$ Reverse circulated to $5550 \mathrm{ft} \mathrm{KB} \mathrm{-} \mathrm{Recovered} \mathrm{frac} \mathrm{sand} \mathrm{-} \mathrm{Pulled} \mathrm{out} \mathrm{of} \mathrm{hole} \mathrm{-}$ recovered three remaining rollers lost from casing roller - shut down for night.

July 11 - Ran 4-3/4-inch bit on 2-7/8-inch drill pipe - washed frac sand from 5550-5570 ft KB - Pressure tested 5-1/2-inch casing using $2 \% \mathrm{KCl}$ water with 500 psig surface pressure for 10 minutes - held OK. Pulled out of hole - laid down jars and 4-3/4-inch bit - picked up Baker 4-1/2-inch OD Retrieving Tool for retrievable bridge plug - started into hole - shut down overnight.

July 12 - Cleaned pits - mixed $100 \mathrm{bbls}$ of $2 \% \mathrm{KCl}$ water - washed sand from 5570-5580 ft KB - released bridge plug - well went on vacuum - pulled and laid down bridge plug - Ran 4-3/4-inch bit to $5500 \mathrm{ft} \mathrm{KB}$. Shut down overnight.

July 13 - Ran 4-3/4-inch bit to $5626 \mathrm{ft} \mathrm{KB} \mathrm{-} \mathrm{Started} \mathrm{taking} \mathrm{weight} \mathrm{-} \mathrm{pulled} \mathrm{out}$ of hole - strap out at $5628 \mathrm{ft}$ - Laid down 4-3/4-inch bit - Picked up 4-inch OD tapered mill - Jars - Ran mill to $2500 \mathrm{ft} \mathrm{KB}$. Shut down for night.

Note: Perforations are from 5600-5630 ft KB.

Casing collars are at $5610 \mathrm{ft}$ and $5640 \mathrm{ft} \mathrm{KB}$

Cement Bond Log indicates poor bond at $5628 \mathrm{ft} \mathrm{KB}$

Baker Model " $D$ " is at $5653 \mathrm{ft} \mathrm{KB}$

Largest $O D$ on Latch in tool is 3.750 inches

Plan to attempt to wash 4-inch OD tool to $5653 \mathrm{ft} \mathrm{KB} \mathrm{-} \mathrm{Not} \mathrm{to} \mathrm{rotate} \mathrm{-} \mathrm{if} \mathrm{can't}$ will pull out of hole and run impression block.

July 14 - Ran 4-inch Mill to $5628 \mathrm{ft}$ - would not go through tight spot - Rotated with tubing tongs and circulated for five minutes - would not go - pulled out of hole - Laid down 4-inch Mill - Mill appeared to be drilling on metal with a bore of about 3-1/2 inches - Ran 4-3/4-inch OD impression block - Set down with 12,000 lbs at $5626 \mathrm{ft}$ - Tight pulling up - Jars tripped - pulled out of hole to $5000 \mathrm{ft} \mathrm{KB}$ - Shut down for night. 
Tuly 15 - Finished pulling of impression block - Block indicates casing collapsed in from one side - no impression on bottom - Picked up Bowen 5-1/2inch casing roller - 4-13/16-inch OD - Ran into hole - started taking wt at $5620 \mathrm{ft} \mathrm{KB}$ - Rotated to $5625 \mathrm{ft}$ - Could not get below $5625 \mathrm{ft}$ - Rotated with $2500 \mathrm{ft}$ lbs torque, $30 \mathrm{RPM}, 500$ to 1000 lbs wt - Additional wt stops power swivel - worked for three hours - no progress - Pulled four stands - shut in well - shut down overnight - Plan to run 4-13/16-inch string mill with 4-inch tapered mill on bottom.

July 16 - Pulled casing roller - ran string pipe mill 4-13/16-inch OD with 4-inch $O D$ tapered mill on bottom - $7 \mathrm{ft}$ below string mill. Ran in hole to 5622 ft KB - Connected power swivel - swivel pump engine locked up - pulled three stands - shut in for repairs.

July 17 - Shut down for rig repairs from 8:00 a.m. to 1:00 p.m. Ran three stands of drill pipe in hole. Rig up drilling equipment - tagged problem section at $5630 \mathrm{ft} \mathrm{KB}$. Milled from 5630-5632 ft - Kicked power swivel out slack off - tagged Model D Packer at $5654 \mathrm{ft} \mathrm{KB}$. Pulled three stands of drill pipe - Shut down overnight.

July 18 - Trip in with three stands drill pipe - tag Model "D" Packer at $5654 \mathrm{ft} \mathrm{KB} \mathrm{-} \mathrm{pick} \mathrm{up} \mathrm{two} \mathrm{feet} \mathrm{and} \mathrm{circulate} \mathrm{off} \mathrm{top} \mathrm{of} \mathrm{packer} 3 / 4 \mathrm{hr}-$ lay down drill pipe and drill collars - change slip segments - stripper head rubber and pipe rams to accommodate 2-1/16-inch tubing. Pick up Baker Latch-In tool with plug nipple and plug on top of Latch-In tool. Pick up two joints 2-1/16-inch tubing. Shut down overnight.

July 19 - Ran 175 joints 2-1/16-inch IJ tubing - pressure tested tubing with rig pump to 1200 psig surface pressure every 20 joints, all tests OK. Tagged packer at $5654 \mathrm{ft} \mathrm{KB} \mathrm{-} \mathrm{Unable} \mathrm{to} \mathrm{latch} \mathrm{into} \mathrm{Model} \mathrm{"D"'.} \mathrm{Shut} \mathrm{down} \mathrm{overnight.}$

July 20 - Pulled Baker tubing plug with wireline equipment - circulated to clean out bore of Model "D" - Pressure up to 1400 psig down tubing when wt is set on Model " $D$ " - Does not latch in - Reverse circulated out small amount of fine metal shavings - Set down on packer - pressured to 1400 psig (maximum output of rig pump) - Held for 10 minutes - Pulled out of hole - Assembly indicates bottom seals apparently going into bore of packer - however seals mostly torn up and some indications of metal damage around bottom seal bottom of tube on seal assembly shows no damage - unable to determine why water was not going into perfs below Model " $D$ " at 1400 psig - Flapper valve would have been open and tube through the bottom of the packer with bottom seals seated in the Model " $D$ " - shut down overnight.

July 21 - Ran Baker Model "A" lockset retrievable packer on 2-1/16-inch tubing to $5500 \mathrm{ft} \mathrm{KB}$ - Unable to get Halliburton or Dowell pump truck for injection test - Moved on Colorado Well Service Triplex - unable to start up pump engine - Down from 10:30 to 2:30 for pump engine repair - got engine 
started - started down hole with packer - got to $5628 \mathrm{ft} \mathrm{KB} \mathrm{-} \mathrm{Unable} \mathrm{to} \mathrm{get}$ any deeper - OD of packer 4.641 inches - Pulled packer out of hole - Marks on packer indicates probable casing collapse again - shut down.

July 22 - Shut down - no standby charge

July 23 - Ran 4-inch tapered mill with 4-7/8-inch string mill section six feet above 4 -inch mill - picked up 2-3/8-inch tubing - tagged Model " $D$ " at $5654 \mathrm{ft} \mathrm{KB}$ - Had no problem through damaged section at $5628 \mathrm{ft} \mathrm{KB}$ - Ran through $5628 \mathrm{ft}$ interval several times - Pulled out of hole - Plan to extend string mill section from 18 inches to about $5 \mathrm{ft}$ and rerun.

July 24 - Ran string mill with flat section of 50 inches, 4-13/16-inch OD, tapered each end - ran with hydraulic jars and 2-3/8-inch EUE tubing - tagged top problem area at $5525 \mathrm{ft} \mathrm{KB} \mathrm{-} \mathrm{would} \mathrm{not} \mathrm{go} \mathrm{through} \mathrm{-} \mathrm{milled} \mathrm{to} 5529.5$ $\mathrm{ft}$ in five hours - unable to get through section - started out of hole - plan to run string mill with 36 inches of flat section and 4-3/4-inch OD.

July 25 - Pulled mill from hole - Mill appears to have been drilling on metal about 4-3/4-inch in diameter - replacement mill was built with OD too large Acme Tool Co. grinding down mill - shut down overnight.

July 26 - Ran string mill 4-3/4-inch OD 36 inches length tapered both ends with 4-inch $O D$ tapered mill $3 \mathrm{ft}$ below string mill - ran in hole with hydraulic jars and 2-3/8-inch EUE tubing - milled out casing from 5529.5-5531 ft KB and milled casing from 5628-5630 ft KB - Tagged Model "D" at $5654 \mathrm{ft} \mathrm{KB} \mathrm{-}$ Reverse circulated at top of Model " $D$ " for 30 minutes - laid down 2-3/8-inch tubing - shut down overnight.

July 27 - Ran Baker Lockset Packer with 2-1/16-inch stinger below 5 ft long with mule shoe - Baker plug receiving nipple above packer - Pan in hole with 2-1/16-inch tubing - Had no problems in previously milled casing points tagged at $5644 \mathrm{ft} \mathrm{KB} \mathrm{-} \mathrm{Washed} \mathrm{down} \mathrm{to} 5647 \mathrm{ft} \mathrm{KB} \mathrm{-} \mathrm{Reversed} \mathrm{out} \mathrm{metal} \mathrm{cut-}$ tings - Set packer and set at $5638 \mathrm{ft} \mathrm{KB} \mathrm{-} \mathrm{could} \mathrm{not} \mathrm{pressure} \mathrm{up} \mathrm{-} \mathrm{circulated}$ up annulus - pulled packer to $5500 \mathrm{ft} \mathrm{KB} \mathrm{-} \mathrm{shut} \mathrm{down} \mathrm{overnight.}$

July 28 - Pulled packer out of hole - had deep scratches around outside in metal - Ran Baker Model "D" milling tool with packer catcher, four 3-1/8-inch drill collars, with 2-3/8-inch tubing - ran to $5500 \mathrm{ft}$ - shut down for night.

July 29 - Tagged apparent damaged section in casing at $5647 \mathrm{ft} \mathrm{KB} \mathrm{-} \mathrm{Milled}$ through section - cleaned out to Model " $D$ " - started milling on Model "D" Packer is apparently going down hole slowly during milling - followed down hole to $5660 \mathrm{ft} \mathrm{KB}$ where packer stopped - started getting rubber back indicating top slips are milled up - packer catcher is not latched below Model " $D$ " - string is free on pickup - will have to mill over bottom slips and allow packer body to drop down hole. 
July 30 - Milled on Model " $D$ " packer - Recovered some rubber in returns. Tripped out of hole. Safety joint was broken allowing packer catcher to collapse. Made up safety joint, ran back in hole with milling tool - latched into Model " $D$ " packer - pulled 30,000 lbs over string wt - Could not move packer - milled on packer. Made unsuccessful attempt to drive packer downhole. Pulled two stands of tubing - String was free on pickup - no drag - Packer is at $5664 \mathrm{ft} \mathrm{KB}$. Shut down for night.

July 31 - Ran two stands of tubing, picked up power swivel and milled on Model "D" from 5664-5667 ft KB. Mill stopped cutting - Tripped out of hole left spring, latch, safety joint, and 2.43-inch $O D$ inside mill off of Baker Model C-1 packer milling - retrieving tool in hole. Shut down for night.

August 1 - Trip in hole with Baker Lockset packer and 2-3/8-inch tubing Set packer $5656 \mathrm{ft} \mathrm{KB} \mathrm{-} \mathrm{Repaired} \mathrm{leaks} \mathrm{in} \mathrm{triplex} \mathrm{pump.} \mathrm{Pump} \mathrm{down} \mathrm{tubing}$ into formation at 1 BPM. Pressure varied from 1300 psi initially to 750 psi. Laid down 2-3/8-inch tubing and 3-1/2-inch drill collars. Changed pipe rams, slip segments, and elevators and prepared to run Baker Lockset packer on 2-1/16-inch tubing. Shut down overnight.

August 2 - Picked up Baker Lockset packer with plug nipple just above packer. Tripped into hole with 2-1/16-inch IJ tubing - spaced out and set packer at $5654 \mathrm{ft}$ KB. Pressured up down tubing - fluid communicated up annulus. Released packer and reset at $5655 \mathrm{ft} \mathrm{KB}$. Fluid communicated up annulus reset packer at $5652 \mathrm{ft} \mathrm{KB}$. No communication. Spaced out and hung tubing in head with packer set at $5652 \mathrm{ft} \mathrm{KB}$. Pressured up down tubing - fluid communicated. Set packer at $5650 \mathrm{ft}$ and fluid communicated. Hung tubing in head, installed well head - shut down overnight.

August 3 - Remove well head - Set Baker Lockset packer at $5642 \mathrm{ft} \mathrm{KB} \mathrm{-}$ Pressure up - Pump into formation at 1400 psi at about 1 BPM. Space out set packer at $5643.5 \mathrm{ft} \mathrm{KB} \mathrm{-} \mathrm{pump} \mathrm{into} \mathrm{formation} \mathrm{OK} \mathrm{-} \mathrm{Hung} \mathrm{tubing} \mathrm{in} \mathrm{head.}$ Nipple up - Rig up to run 1.9-inch OD tubing - Run 40 joints tubing-tong head broke - shut down overnight.

August 4 - Pick up 133 joints 1.9-inch OD tubing (total of 173 joints) landed at $5572 \mathrm{ft} \mathrm{KB}$. Hung in well head - Remove BOP's - lower split tubing hangers install well head - Rig up to swab.

August 5 - Shut down - No standby charge

August 6 - Swabbed liquid level from $300 \mathrm{ft}$ to $4200 \mathrm{ft}$ through 1.90 -inch IJ tubing string - No gas entry - shut down overnight.

August 7 - Found liquid level at $2000 \mathrm{ft}$ from surface - swabbed down to $4000 \mathrm{ft}$ making four to five runs per hour - No gas entry yet - shut down overnight. 
August 8 - Found liquid level at $3800 \mathrm{ft}$ from surface - swabbed down to $5570 \mathrm{ft}$ - Pulling two runs per hour, $1000 \mathrm{ft}$ liquid per run - Casing pressure built up to 25 psig - shut in overnight.

August 9 - Found liquid level at $4300 \mathrm{ft}$ from surface - casing pressure built up to 40 psig overnight - Swabbed down to $5570 \mathrm{ft}$ - Pulling two runs per hour 600 to $800 \mathrm{ft}$ of liquid per run - Casing pressure built up to $50 \mathrm{psig}$ - Shut in for night - EIC analysis of water and gas indicates no radioactivity from nuclear detonation.

August 10 - Found liquid level at $4300 \mathrm{ft}$ from surface casing - pressure 70 psig - built up to 70 psig overnight - Swabbed down to $5570 \mathrm{ft}$ - Making two swab runs per hour, pulling 400-500 ft of liquid per run - casing pressure built up to 75 psig - Shut in for night.

August 11-12 - Shut down - No standby charge

August 13 - Found casing pressure at 95 psig, liquid level at $3800 \mathrm{ft}$ from surface. Swabbed well down to $5570 \mathrm{ft}$ - Making two runs per hour, pulling 400-500 ft per run. Casing pressure went down to 80 psig - Shut in overnight.

August 14 - Found casing pressure at 95 psig - liquid level at $4300 \mathrm{ft}$ from surface. Swabbed well down to $5570 \mathrm{ft}$ - Making two runs per hour - pulling 400-500 ft of liquid per run - Casing pressure went down to $90 \mathrm{psig}$. Shut in overnight.

August 15 - Found casing pressure at 100 psig - Liquid level at $4300 \mathrm{ft}$ from surface. Swabbed well down to $5570 \mathrm{ft}$ - making two runs per hour - Pulling 400-500 ft of liquid per run - casing pressure went down to 90 psig - Ran swab down 2-1/16-inch tubing - found liquid level at $900 \mathrm{ft}$ from surface $2-1 / 16$-inch string had 10 psig at surface - shut in well overnight.

August 16 - Found casing pressure at 110 psig - Liquid level at $4400 \mathrm{ft}$ from surface - Swabbed well down to $5570 \mathrm{ft}$ Making one run per hour - Pulling 700$800 \mathrm{ft}$ per run - Casing pressure went down to $100 \mathrm{psig}$ - Shut well in for night. Caught samples of recovered liquid to send to Dowell Research Laboratory for analysis and evaluation for planned stimulation job - Liquid appears dark-colored and is carrying very fine sediments.

August 17 - Found casing pressure at 140 psig - 2-1/16-inch tubing pressure 0 psig - 1.90-inch tubing pressure at 25 psig - Liquid level at $4500 \mathrm{ft}$ from surface - swabbed well down to $5570 \mathrm{ft}$ - Making one run per hour, pulling 600-700 ft per run - Casing pressure remcined at 150 psig - Shut well in for night. 
August 18 - Found casing pressure at 150 psig - 2-1/16-inch tubing pressure 0 psig - 1.90-inch tubing pressure at 25 psig - Liquid level at $4600 \mathrm{ft}$ from surface - Swabbed well down to $5570 \mathrm{ft}$ - Making one run per hour pulling 600 to $700 \mathrm{ft}$ per run - Casing pressure remained at 150 psig - Shut well in for night.

August 19 - Shut down - No standby charge.

August 20 - Found casing pressure at 200 psig - 2-1/16-inch tubing pressure at 50 psig - 1.90-inch tubing pressure at 55 psig - Liquid level at $4500 \mathrm{ft}$ from surface. Swabbed well down to $5570 \mathrm{ft}$ - Making one run per hour pulling 500-600 ft per run - Casing pressure remained at 200 psig. Shut in well for night.

August 21 - Found casing pressure at 225 psig - 2-1/16-inch tubing pressure at 25 psig - 1.90-inch tubing pressure at 50 psig - Liquid level at $4700 \mathrm{ft}$ from surface - Swabbed down to $5570 \mathrm{ft}$ - Making one run per hour, pulling $600 \mathrm{ft}$ of liquid per run - casing pressure remained at 225 psig - Shut down overnight.

August 22 - Found casing pressure at 240 psig - 2-1/16-inch and 1. 90 -inch tubing pressures at 50 psig - Liquid level at $4700 \mathrm{ft}$ from surface - Swabbing from $5570 \mathrm{ft}$ - Making one run per hour pulling $600 \mathrm{ft}$ of liquid per run casing pressure remained at 240 psig - Shut down overnight.

August 23 - Found casing pressure at 270 psig - $2-1 / 16$-inch at 25 psig, 1.90inch at $60 \mathrm{psig} \mathrm{-} \mathrm{Liquid} \mathrm{level} \mathrm{at} 4700 \mathrm{ft}$ from surface - Swabbing well from $5570 \mathrm{ft}$. Making one run per hour, pulling 500-600 ft of liquid per run, casing pressure went up to 280 psig - well unloaded and flowed for 15 minutes then died, casing pressure down to 240 psig - Shut well in - Moved off workover rig - Preparing to stimulate well on August 24.

August 24 - Found casing pressure at 270 psig - 2-1/16-inch tubing pressure at 50 psig - 1.90-inch tubing pressure at 80 psig - connected Dowell and Nowsco lines and pressure tested - Pumped in $70 \mathrm{bbls}$ of inhibited gas well acid mixed with 12,000 scf of $\mathrm{N}_{2}$ at 2300 psig - Casing pressure at end of displacement was 1800 psig - Connected lines to annulus and displaced gas well acid into perfs (5600-5630 ft) with $80,000 \mathrm{scf}$ of $\mathrm{N}_{2}$. Final and maximum pressure was 3200 psig - Immediate SIP 3200 , 15 minute SIP 3200 psig. At 70,000 scf displacement down annulus, pressure on $2-1 / 16$-inch tubing increased to 1200 psig - No breaks in pressure while spotting or displacing acid - Left well shut in for one hour and started flowing well to pit from 1. 90-inch tubing at 1:45 p.m. - Well died at 8:00 p.m. - had 80 psig on annulus - had 60 psig on 2-1/16-inch tubing string - Shut in well overnight.

August 25 - Found 750 psig on annulus, 200 psig on 2-1/16-inch tubing, opened up 1.90-inch tubing to pit - would not unload - moved on workover rig and rigged up - Swab carrier threads were damaged - Waited on new 
carrier - Swabbed two hours, liquid level at $3000 \mathrm{ft}$ from surface - Casing pressure at 4:00 p.m. 850 psig. Shut down overnight.

August 26 - Shut down.

August 27 - Found casing pressure at 1100 psig - 2-1/16-inch tubing pressure at 200 psig, 1.90-inch tubing pressure at 700 psig - Opened well to pit from 1. 90-inch string - Well would not unload - Swabbed well in - Flowed for two hours and died - Casing pressure went down to 400 psig - Swabbing from $5570 \mathrm{ft}$, making two runs per hour and pulling $1000 \mathrm{ft}$ of liquid per run - Well comes in and flows for about 10 minutes and dies - Casing pressure staying at 300 psig Shut well in at 4:00 p. m. Casing pressure at 300 psig.

August 28 - Found casing pressure at 600 psig - 2-1/16-inch tubing pressure at 200 psig - Opened well to pit from 1.90-inch string - Well died - Casing pressure would not unload well - Found liquid level at $3800 \mathrm{ft}$ from surface Swabbed well in - flowed for two hours and died - Making one swab run per hour from $5570 \mathrm{ft}$ - Well flows for about 30 minutes and dies. Casing pressure remaining at 250 psig - Shut well in at 4:00 p. m. - Casing pressure at 250 psig.

August 29 - Found casing pressure at 475 psig - 225 on 1.90 -inch tubing. Opened to pit, well would not unload - Found liquid level in 1.90 -inch at $4300 \mathrm{ft}$ from surface. Swabbed well in, flowed for one hour and died. Cas ing pressure went down to 250 psig - making one swab run per hour. Well flows about 30 minutes and dies - Casıng pressure remaining at 250 psig shut well in at 4:00 p. m. - Casing pressure at 250 psig. Shut down overnight.

August 30 - Found casing pressure at 475 psig - 2-1/16-inch tubing pressure 200 psig - 1.90 -inch tubing pressure 225 psig. Opened to pit from 1.90 -inch tubing - would not unload. Found liquid level in 1.90 -inch at $4300 \mathrm{ft}$ from surface - Swabbed well in - flowed for 45 minutes and died - casing pressure went down to 250 psig - making one swab run per hour, well flows about 30 minutes and dies - Casing pressure remaining at 250 psig. Shut well in at 4:00 p. m., casing pressure 250 psig. Shut down overnight.

August 31 - Found casing pressure at 475 psig - Shut down swabbing Moving in $400 \mathrm{bbl}$ tank and circulating equipment. Pumping water to mix $2 \% \mathrm{KCl}$ water to kill well for planned frac on zone $5082-5128 \mathrm{ft}$ on about September 7, 1973 .

September 1 - Found casing pressure at 850 psig - Pumping water to 400 bbl tanks, rigging up circulating equipment.

September 2-3 - Shut down, casing pressure 1000-1100 psig. No standby charge. 
September 4 - Casing pressure 1200 psig - Blew well down - Mixed 900 bbls of $2 \% \mathrm{KCl}$ water with 2 gal Adamol per 1000 gal water - Killed well down 1.90inch tubing with 125 bbls. Filled 2-1/16-inch tubing with 2 bbls - Installed Shaffer double gate Hydril BOP - Rigged up floor - Worked for three hours trying to release Baker Lockset Packer - Could not release - Shut well in Preparing to circulate down near top of packer with 1.90 -inch tubing before pulling 1.90-inch tubing from hole.

September 5 - Circulated to $5640 \mathrm{ft} \mathrm{KB}$ with bottom of 1.90-inch tubing Pulled 1.90-inch tubing from hole - Released Lockset Packer and pulled 2-1/16-inch tubing. Shut down overnight. (Laid down 15 joints each of 1.90inch and $2-1 / 16-$ inch).

September 6 - Moved in 2-7/8-inch EUE Tubing - Ran Baker 5-1/2-inch casing scraper on 2-7/8-inch tubing to $5378 \mathrm{ft} \mathrm{KB}$. Started out of hole. Shut down overnight.

September 7 - Finished pulling 2-7/8-inch tubing, laid down casing scraper. Rigged up Dresser Atlas to $\log$ and perforate. Ran CBL-Variable Density Log from 5400-4500 ft. Bond log was identical to Bond Log run on 4/25/70 prior to the nuclear stimulation. Perforated upper Fort Union sand interval with $18 \mathrm{NCF}-\mathrm{V}$ jets as follows: $5084,86,88,90,94,97,98,5100,02,06$, $08,10,12,14,16,22,24,5126 \mathrm{ft} \mathrm{KB}$. Rigged down Dresser Atlas, Ran Baker Model "C" Retrievable Bridge Plug and Model "E" Retrievable Packer on 2-7/8-inch tubing. Set Bridge Plug at $5327 \mathrm{ft} \mathrm{KB}$ and Model "E" at $5010 \mathrm{ft}$ $\mathrm{KB}$. Shut down overnight.

September 8 - Rigged up Dowell to frac interval from 5084-5126 ft KB. Pressured annulus to 1000 psig using rig pump. Dowell tested lines to 7300 psig Held OK. Fraced with 10,000 lbs of 20-40 sand and 2900 lbs 10-20 sand. Average sand concentration was 3/4\#/gallon. Average rate 12.5 BPM with approximately $1200 \mathrm{SCF} / \mathrm{bbl}$ of $\mathrm{CO}_{2}$. Used total of 40 tons of $\mathrm{CO}_{2}, 520 \mathrm{bbls}$ of $2 \% \mathrm{KCl}$ water mixed with 2 gal of Adamol per 1000 gal of water. Job started at 10:30 a.m. - finished at 11:13 a.m. Started flowing to pit at 12:05 p.m. Formation broke down at 5500 psig. Broke back to 4500 psig. ISIP 1600 psig. Blew well overnight. Making $\mathrm{CO}_{2}$ and water - Gas started burning continuously after six hours of flowing. Estimate 300-400 bbls of water flowed back.

September 9 - Well still flowing - estimate water production at 1 bbl per hour and slowly decreasing. Estimate gas rate at 100-150 MCF/D. Shut in well for buildup at 9:15 a. $\mathrm{m}$.

September 10 - Surface tubing pressure 960 psig - Well shut in - Rig shut down.

September 11 - Surface tubing pressure 1380 psig - Well shut in - Rig shut down. 
September 12 - Surface tubing pressure 1510 psig at 8:00 a.m. Started flowing well to pit at 12:30 a.m. with 2-inch Critical Flow Prover with 0.125 -inch orifice. Initial pressure 1515 psig. Stabilized at 930 psig. Rate \#1 = $322 \mathrm{MCF} / \mathrm{D}$, changed to 0.250 -inch orifice - stabilized at 330 psig, Rate \#2 - $480 \mathrm{MCF} / \mathrm{D}$, changed to 0.375 -inch orifice. Stabilized at 150 psig Rate \#3 = $498 \mathrm{MCF} / \mathrm{D}$. Shut well in at 1:45 a.m., September 13. Well built up to 1210 psig at 8:00 a.m. September 13 .

September 13 - Bled well down to pit - killed well down 2-7/8-inch tubing with $40 \mathrm{bbls}$ of $2 \% \mathrm{KCl}$ water mixed with 2 gals of Adamol per 1000 gals of water. Released Baker Packer - Reversed out $20 \mathrm{ft}$ of frac sand from above Baker Bridge Plug. Released Bridge Plug. Lost $80 \mathrm{bbls}$ of $2 \% \mathrm{KCl}$ water while reversing out sand. Started out of hole with bridge plug and packer, laying down 2-7/8-inch tubing. Shut down overnight.

September 14 - Laid down remainder of 2-7/8-inch tubing and Baker Bridge Plug and Packer - Ran Baker Model "F.H." double grip Hydrostatic packer on 163 joints of 2-1/16-inch tubing - Hydrotested tubing into hole - laid down

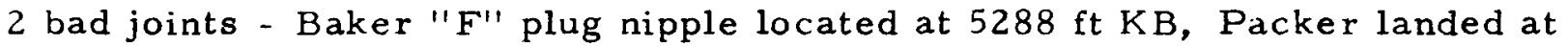
$5293 \mathrm{ft} \mathrm{KB}$. Halliburton circulated hole with $33 \mathrm{bbls}$, dropped ball and pumped down 2-1/16-inch with 12 bbls, pressured up and set packer, Ball sheared out of packer at 2200 psig. Pumped down 2-1/16-inch at $1-1 / 2$ BPM at 1000 psig for 3 minutes, no water returns to surface. Annulus went on vacuum while pumping down 2-1/16-inch tubing. Released Halliburton. Shut in well. Shut down overnight.

September 15 - Found no pressure on well. Rigged up to run 1.90-inch IJ tubing - Ran $3 \mathrm{ft}$ pinned joint on bottom and 158 joints of 1.90 -inch tubing landed at $5084 \mathrm{ft} \mathrm{KB}$. Removed BOP and installed dual wellhead, rigged up to swab 1.90-inch tubing - Found liquid level at $300 \mathrm{ft}$, made $6 \mathrm{swab}$ runs. Shut down overnight. (Laid down 11 bad joints of 1.90 -inch tubing).

September 16 - Swabbed well down to $1600 \mathrm{ft}$, casing pressure at 600 psig well started flowing gas and water to pit - Let well flow overnight to clean up. Estimated rate $250 \mathrm{MCF} / \mathrm{D}$. Well appears to be cleaning up and rate increasing.

September 17 - Well flowed to pit to clean up until 4:30 p. m., Shut in well. Estimated rate at shut-in $450 \mathrm{MCF} / \mathrm{D}$. Released pulling unit and moved off of hole. Pressure at 8:00 a.m. September 18 - Tubing Pressure at 1340 Casing pressure at 1400 psig. 
REMEDIAL WORK - November 23 - December 5, 1974

1974

November 23 - Nippled down tubing head. Total depth $7895 \mathrm{ft}$. Plugback total depth $6460 \mathrm{ft}$. Workover unit on location at 0930 , moved in and rigged up. Dowell pump truck did not show. Called Halliburton. Pump truck on location at 1430. Mixed 550 bbls of $2 \% \mathrm{KCl}$ water and killed annulus by pumping 25 bbls water down 1.9-inch tubing and 100 bbls water down 5-1/2inch casing. Pump down overnight.

November 24 - Rigged up to pull 2-1/16-inch tubing. Unit operation der rick man did not show up for work. Found well had frozen up, used EIC steamer to thaw same. Nippled down wellhead, nippled up BOP. Pulled 1.9-inch tubing out of hole. Started rigging up to pull 2-1/16-inch tubing and Baker Model FH packer out of hole.

November 25 - Total depth $7895 \mathrm{ft}$. Plugback total depth $6460 \mathrm{ft}$. Finished rigging up to pull 2-1/16-inch tubing and packer. Filled annulus with 23 barrels of water. Pulled 50,000 lbs on packer. Would not release. Rigged up wire line truck and pulled Baker Model FWG plugs out of seating nipple at $5288 \mathrm{ft}$. Pumped $27 \mathrm{bbls}$ of water down 2-1/16-inch tubing at $1-1 / 2 \mathrm{bar}$ rels per minute at 800 psig. Established communication with annulus with 19 barrels. Rigged down Halliburton. Shut well in overnight.

November 26 - Pumped 25 barrels of $2 \% \mathrm{KCl}$ water in annulus. Picked up 38, $000 \mathrm{lbs}$ on 2-1/16-inch tubing and released packer. Pulled out of hole laid down 172 joints of 2-1/16-inch IJ tubing. Laid down Baker Model FH packer. Filled hole with 35 barrels of water. Shut well in. Tallied 172 joints of new 2-1/16-inch IJ tubing. 2 joints of 172 were bad.

November 27 - Found no pressure on well. Pump froze up. Did not pump $2 \% \mathrm{KCl}$ water. Picked up redressed Baker Model FH hydrostatic packer with Baker Model F nipple $5 \mathrm{ft}$ above packer. Went in hole with 94 joints 2-1/16-inch IJ tubing. Hydrotested each joint into hole with 3250 psig. Bottom packer of hydrotester tool locked up approximately $70 \mathrm{ft}$ down hole in 92 nd joint into hole. Unable to release - laid down 3 joints. Found hydrotested packer $1 \mathrm{ft}$ before box end of $92 \mathrm{ndjoint}$ into hole. Well required welder to split joints into recovered tool. Filled hole with 20 barrels of $2 \%$ $\mathrm{KCl}$ water. Shut in well. Found no leaks in 91 joints currently in hole.

November 28 - Shut down for Thanksgiving.

November 29 - Found no pressure on well. Pump froze up. Laid Baker Model FH packer to $5262 \mathrm{ft}$ GL with 167 joints 2-1/16-inch IJ tubing. Baker 
F Nipple at $5257 \mathrm{ft}$ GL. Hydrotested all 2-1/16-inch IJ tubing in hole to minimum pressure of 3000 psig. Filled hole with $2 \% \mathrm{KCl}$ water. Set packer and sheared out ball at $2700 \mathrm{ft}$ psig. Pumped 10 barrels of $2 \% \mathrm{KCL}$ water down 2-1/16-inch tubing at 1-1/2 barrels per minute and 1300 psig casing or on vacuum. Shut well in. Started rigging up to run 1.90-inch IJ tubing.

November 30 - Found no pressure on well. Pumped no water into hole. Ran 155 joints of 1.90 -inch IJ tubing with $3 \mathrm{ft}$ bent joint on bottom. Landed 1.90inch IJ tubing at $4969 \mathrm{ft}$ GL. Removed BOP's. Installed wellhead and pressure tested seals to 3000 psig. Held OK. Rigged up and unloaded tubing on casing side with nitrogen. Shut well in.

December 1 - Found well on vacuum. Connected Nowsco to 1.90-inch tubing string. Displaced 80 barrels of water up annulus with 60,000 SCF nitrogen into flat tank. Maximum 2500 psig. Unloaded water. Shut down nitrogen injection. Let well flow for 2 hours at rate of approximately 1 MMSCF per day. No water to surface after initial 80 barrels. Surface tubing pressure 1500 psig. Started to change flow from casing to tubing. Master valve on wellhead tubing tree would not hold pressure. Left Nowsco valve on head. Disconnected Nowsco truck. Will have to kill well, change out master valve and unload well with nitrogen. Shut in overnight - arranged for Halliburton for December 2, 1974 a.m. EIC checked recovered water. No detectable tritium in water.

December 2 - Killed well with 150 barrels $2 \% \mathrm{KCl}$ water. Changed out master valve on 1.90-inch IJ tubing side. Connected Nowsco to 5-1/2-inch x 1.90inch annulus. Unloaded well with 100,000 SCF nitrogen. Maximum pressure 2500 psig. Left well flowing overnight.

December 3 - Full well flowing at estimated rate of 125 MCF per day, fine water mist with gas. Shut well in, released $R \& R$, started tie-in of well to separator.

December 4 - Finished tie-in of well to separator. Tied in water injection line to 2-1/16-inch tubing string. Serviced all WKM valves on wellhead.

December 5 - Installed building over wellhead. Finished heat taping water injection line. 


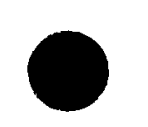

$-74-$ 


\begin{abstract}
APPENDIX C
PERMIT FOR SUBSURFACE DISPOSAL FINDINGS OF FACT, PUBLIC HEARING ON WATER DISPOSAL APPLICATION
\end{abstract}

WATER QUALITY CONTROL DIVISION

COLORADO DEPAR TMENT OF HEALTH

November 9, 1973

\begin{abstract}
APPLICATION OF CER - GEONUCLEAR ) CORPORATION AND THE CONTINENTAL ) OIL COMPANY TO OPERATE A SUBSURFACE ) DISPOSA L SYSTEM UPON AND UNDER A ) TRACT OF LAND 739 FEET FROM THE ) WEST LINE AND 2357 FEET FROM THE ) NORTH LINE OF SECTION 14, T3S, ) R98W, RIO BLANCO COUNTY, COLORADO )
\end{abstract}

\author{
PERMIT FOR \\ SUBSURFACE DISPOSAL
}

1. The Colorado Water Quality Control Commission has found, after Public Hearing and due consideration, that subsurface disposal, as proposed in the application by CER Geonuclear Corporation and the Continental Oil Company, could take place within the meaning of Section 66-28-505(1) of the Colorado Water Quality Control Act of 1973.

2. The Colorado Water Quality Control Division hereby grants CER Geonuclear and the Continental Oil Company a permit for the operation of a subsurface disposal system as provided for in Section 66-28-505(2) of the Act and as provided for in Section 3(d) of the Emergency Rules for Subsurface Disposal Systems, effective October 16,1973; subject to the following conditions and stipulations:

A) Discharge under this permit may occur for a period of twelve months beginning on November 10, 1973.

B) Total volume injected shall not exceed 24,000 barrels (42 gal. /bbl) and concentration of tritium shall not exceed $0.05 \mathrm{mic}$ ro $\mathrm{Ci} / \mathrm{ml}$.

C) Injection pump pressure shall not exceed 1800 p.s.i.g.

D) Injection interval shall be from 5600 feet to 6072 feet.

E) Construction of the system and appurtenances, either as constructed or to be constructed, shall conform to the plans and specifications as 
proposed in the Project Rio Blanco - Subsurface Water Disposal Application submitted by CER Geonuclear June 11, 1973, except that the disposal interval includes the zone from 5600 to 5630 feet, as subsequently amended by the applicant.

F) Operational procedures, including alarm systems, shall be implemented as proposed in the application referred to above.

G) If testing of the RB-E-01 well and subsequent disposal into the Fawn Creek Government No. 1 well (proposed disposal system) is conducted in phases, the Water Quality Control Division and the Occupational and Radiological Health Division of the Colorado Department of Health shall be notified immediately upon completion of the testing period and at least five days before the resumption of a new testing period.

H) Any deviation from testing or injection procedures as outlined in the application referred to in (E) above shall require prior approval of the Water Quality Control Division and shall be requested in writing in sufficient time to provide adequate time for review and approval.

I) Employees of Department of Health and Department of Natural Resources shall be allowed access to the site without prior notification for purpose of observation of operations and sample collection of waste and/or products. Such access, however, to be subject to established health and safety precautions.

J) This permit shall not be assigned nor operations contracted to another party without prior written approval of the Colorado Water Quality Control Division.

3. Monitoring shall be conducted by CER Geonuclear and the Continental Oil Company as follows:

A) Samples of gas and injected fluid shall be analyzed for chemical and radiological constituents from the locations and at the frequencies indicated in Exhibit "A". Analyses shall be performed by the applicant's laboratory or an independent laboratory approved by the $D$ ivision and the results of the analyses certified.

B) Upon request of the Colorado Water Quality Control Division, the applicant shall promptly furnish, at the time intervals indicated and at the applicant's cost, samples for analysis by the Colorado Department of Health. The samples shall be in the quantity and from the locations as specified by the Division and shall be properly labeled.

C) CER Geonuclear Corporation and Continental Oil Company, by undertaking the discharge which is the subject of the application, agree 
to perform such additional monitoring procedures and installations as may be required upon subsequent review by the Division, at the expense of the applicants.

4. All rules, regulations, orders, guidelines, etc., by the Colorado Water Quality Control Commission presently in effect, as well as any subsequent rules or regulations adopted by the Commission, shall be observed by the applicants.

5. This authority to discharge shall terminate in all respects, except for such monitoring and reporting procedures as required in Exhibit " $A$ ", twelve months from the effective date, unless the Colorado Water Quality Control Division shall extend the termination date.

6. This permit shall in no way be construed to relieve the applicants from complying with the requirements and regulations of other State and Federal regulatory agencies, including the Occupational and Radiological Health Division of the Colorado Department of Health. Nothing herein contained shall be construed to relieve the permittees from the observance of, performance of, or compliance with, any conditions, duties, or obligations imposed by any order, permit or license issued by any agency of the State of Colorado.

BY ORDER OF THE COLORADO WATER QUALITY CONTROL DIVISION

s/Frank J. Rozich

Frank J. Rozich, P.E.

Director, Colorado Water

Quality Control Division
S/Roy L. Cleere

Roy L. Cleere, M. D. . M. P.H.

Executive Director, Colorado

Department of Health 


\section{WATER QUALITY CONTROL DIVISION \\ COLORADO DEPARTMENT OF HEALTH}

November 9, 1973

MONITORING PROCEDURES FOR
SUBSURFACE DISPOSAL SECTION 14, )
T3S, R98W, RIO BLANCO COUNTY, ;
COLORADO

As a condition of the permit for subsurface disposal, CER Geonuclear and Continental Oil Company shall perform the following monitoring procedures:

1. Gas and water sampling schedules and analyses as proposed in the application (Table IVD-1, Page 94), shall also include an analysis for tritium for the gas and water produced from the disposal well (Fawn Creek Government No. 1). Results of the chemical and radiological analyses of the samples will be submitted to the Division within five days after the completion of the analyses.

2. Water injection rates and pressures shall be monitored continuously and recorded on a daily basis. Daily records shall indicate the maximum injection pump pressure as well as the average (or operating) pressure and rate. Daily records, including volume, shall be submitted monthly in duplicate to the Division by the tenth day of the month for the proceeding month, or ten days after the completion of any testing period.

3. The disposal well shall be shut down and a pressure fall off test performed at each ten day interval and at the conclusion of any testing period. The shut down period is to be as long as necessary to obtain conclusive results. Data and/or charts are to be submitted to the Division within five days after completion of the pressure fall off test.

4. Water samples shall be collected and analyzed for radioactive constituents from the following wells: RB-D-01, RB-S-03, and RB-W-01 (W-1), as identified and located on Plate 11 of the Project Rio Blanco - Subsurface Water Disposal Application.

Collection and analysis shall be weekly throughout the disposal period and for one month thereafter. If no anomalous amounts of radioactive constituents are observed during this period, then collection and analysis shall be on a monthly basis for twelve months after injection has terminated. If at any time anomalous amounts of radioactive constituents are observed, the injection system shall be shut down and the Water Quality Control Division promptly notified. Reinjection shall not be started without permission from the Division. 
Monitoring procedures and conditions outlined above are supplemental to the present monitoring program required in the Permit for Subsurface Nuclear Detonation and in no way relieves CER Geonuclear from the requirements of the previous permit. 
IN THE MATTER OF APPLICATION OF C.E.R. ) GEONUCLEAR CORPORA TION ENTIT LED :'PROJECT ) RIO BLANCO SUBSURFACE WATER DISPOSAL ) APPLICATION" DATED JUNE 11, 1973, AS FINDINGS OF FACT AMENDED

This matter came on for public hearing on September 24, 1973 before John Phillip Linn, Hearing Officer for the Water Quality Control Commission, State of Colorado. The hearing was closed the same day.

Continental Oil Company, the unit operator of the Rio Blanco unit, whose employees and executives are making the management decisions concerning Project Rio Blanco, was admitted as a party to the proceedings.

C. E. R. Geonuclear Corporation, hereinafter referred to as Petitioner, and Continental Oil Company were represented by James D. Voorhees, Esq., of the firm Moran, Reidy \& Voorhees, Denver, Colorado.

William Tucker, Assistant Attorney General, State of Colorado, appeared on behalf of the Water Quality Control Commission.

\section{FINDINGS OF FACT}

1. The Water Pollution Control Commission of the State of Colorado approved the Petitioner's request for a permit in regard to a nuclear detonation plan for Rio Blanco County, applicable to Phase One only of Project Rio Blanco, on May 4, 1973, nunc pro tunc as of April 17, 1973.

2. Three 30 kiloton nuclear explosives, especially designed for gas stimulation purposes, which had been placed in the Project Rio Blanco Well No. RB-E-0l bore at depths of 5840, 6230 and 6690 feet below the surface of the earth, were detonated on May 17, 1973. The simultaneous explosions of the detonations created a cylindrical chimney, having an ove rall height of approximately 1,350 feet and a radius from the center line of the chimney of some 80 feet. The maximum extent of fracture from the centerline of the chimney is less than 400 feet. The object of the detonation was to fracture various sandstone layers or lenses in which natural gas occurs.

3. The chimney exists within the base of the Fort Union Formation and the top of the Mesa Verde Formation. Between the top of 
the chimney and the surface of the earth are approximately 1,000 feet of Fort Union Formation; over 2,000 feet of Wasatch Formation; and some 3, 000 feet of the Green River Formation.

4. Contained within the chimney interval are some five million feet of void volume into which an estimated 540,000,000 standard cubic feet of natural gas has flowed. The gas in the chimney is expected to consist primarily of methane $\left(\mathrm{CH}_{4}\right)--54$ to 42 volume percent; carbon dioxide $\left(\mathrm{CO}_{2}\right)--30$ to 25 volume percent; hydrogen $\left(\mathrm{H}_{2}\right)--10$ to 13 volume percent; and water vapor $\left(\mathrm{H}_{2} \mathrm{O}\right)--6$ to 20 volume percent.

5. Following detonation of the Project Rio Blanco, the Oil and Gas Conservation Commission of the State of Colorado authorized Petitioner to re-enter and test Well No. RB-E-0l of the Project Rio Blanco by its Order No. 264-2 dated July 17, 1973.

6. The Petitioner now seeks a permit approving the underground disposal of radioactive waste, i. e., tritiated water separated during the testing of Well No. RB-E-01, as part of the Second Phase of the Project Rio Blanco experiment, which is a joint activity of the Atomic Energy Commission and Petitioner to determine the feasibility of using nuclear explosives in the production of natural gas from formations which will not produce under conventional methods.

7. The petitioner expects to produce $300,000,000$ standard cubic feet of natural gas, but there is a contingency to produce up to $800,000,000$ standard cubic feet of natural gas, during the testing period.

8. The radioisotopes of primary interest in all of the natural gas created by the explosion are krypton- $85\left({ }^{85} \mathrm{Kr}\right)$--something less than 2,000 curies; and tritium $\left({ }^{3} \mathrm{H}\right)$--something less than 3,000. Three thousand curies is the equivalent of approximately $3 / 10 \mathrm{~s}$ of a gram of tritium. Essentially all of the ${ }^{85} \mathrm{Kr}$ and about 10 percent of the ${ }^{3} \mathrm{H}$ are mixed with the chimney gas. Other contributions to the total radioactivity of the chimney gas are small amounts of carbon-14 ( $\left.{ }^{14} \mathrm{C}\right)$; $\operatorname{argon-37}\left({ }^{37} \mathrm{Ar}\right)$; and argon-39 ( $\left.{ }^{39} \mathrm{Ar}\right)$.

9. Through Well No. RB-E-01, re-entry will penetrate the chimney and fractured zone, and at the conclusion of the re-entry conventional production separation equipment will be placed on the surface of the earth. Gas from the chimney will be produced up the well bore as a result of the pressure and temperature decrease during this production and some water will condense from the vapor phase and be separated as liquid water in the separator.

10. The Applicant proposes to reinject the water produced in the Rio Blanco Project into the formation and area from which it came in order to minimize the amount of radioactivity to the biosphere during the 
testing of the project re-entry well. This water will be stored in four $400-$ barrel. storage tanks, analyzed for its radioactivity and other contents, and then be re-injected through a 2 -inch line into the Fawn Creek Government Number $1 \mathrm{Well}$, some 1320 feet to the south, into an area essentially opposite of the chimney and in the same lower Fort Union Formation.

11. Hydrocarbon condensate, which will condense out in the separator, will be sent to condensate storage tanks, be checked for radioactivity, be pumped up the flare stack and be burned along with the gas.

12. Tritium concentrations in the water produced along with the gas, which will be separated at the surface of the earth, will be 0.05 micro-curies per milliliter, or .05 millions of a curie of tritium per milliliter of water. This is 16 times greater than the present standard accepted for drinking water as published by the Federal Radiation Council and the International Council for Radiation Protection, which is . 003 micro-curies per milliliter for an individual, and .001 micro-curies per milliliter for the populous at large.

13. Tritium is an isotope of hydrogen, having a mass of three. It is a unique radioactivity of the isotope hydrogen. It decays with a 12.26 year half life, emitting exclusively beta particles. Half life is a convenient representation of the life time that the radionuclide exhibits. A half life of 12 . 26 years means a given quantity of tritium will be reduced to one-half that level in a period of 12.26 years, and will be one-fourth of the initial amount in two one-half lives, or 24 years. Tritium decays into inactive helium-3. Water having .05 micro-curies of tritium per milliliter would take approximately 50 years to decay to .003 micro-curies per milliliter, and would take approximately 70 years to decay to .001 micro-curies per milliliter. Consequently, water which will be produced from and during the testing of the RB-E-0l Well will be potable in approximately 70 years on the basis of present knowledge and under existing standards.

14. In the production of $300,000,000$ standard cubic feet of natural gas from Well No. RB-E-01, some 296 curies of tritium will be produced, of which 50 curies will be separated in the separator in the liquid water condensed from the gas phase and be diluted in 6, 500 barrels of water. That 6,500 barrels of water will be injected into the Fawn Creek Government Number 1 Well. The remaining 246 curies of tritium existing in the gas will be metered, sent to the flare stack, and burned off into the atmosphere.

15. If production of natural gas goes to the full $800,000,000$ standard cubic feet, the total tritium production from the well will be 580 curies, of which 130 curies would be diluted in 20,000 to 24,000 barrels of water which would be injected into the Fawn Creek Government Number 1 Well. The remaining 450 curies of tritium existing in the gas would be metered, sent to the flare stack, and burned off into the atmosphere. In any case, the krypton- 85 and carbon- 14 will have to be flared into the atmosphere. 
16. Radiological protection and documentation of radioactive effluents will be provided until the end of the production testing and subsequent site rollup. It is expected that measurable quantities of radioactivity will be deposited in the immediate vicinity of both the Emplacement Well, No. RB-E-01, and the flare stack areas. Water samples will be collected immediately before and after the flaring operation at each of six locations. Intermediate samples will be taken at intervals of 3 days. Additional samples will be collected at two class locations weekly during and after the flaring operation for a period of at least 4 weeks, extending until at least 1 week following the conclusion of flaring. These samples will be assayed for tritium activity by liquid scintillation methods and for other nuclides by gamma spectrometry. Meteorological and ecological studies indicate that even with release of all gaseous radioactivity to the atmosphere, the maximum commitment in the vicinity will be much less than 1 percent of the annual natural background radiation.

17. The Fawn Creek Government Number 1 Well, into which the tritiated water will be injected, was drilled by Equity Oil Company in 1958. The Petitioner tested two intervals in 1969. Then, in early 1973, Petitioner perforated additional sand lenses and ran a water injectivity test which showed that the rate of water influx into the sand intervals of 5745 to 6072 feet was in excess of 3,000 barrels a day at 1,500 psi surface pressure. The interval from 5600 to 5630 feet was shown from experience to take water. In early September, 1973, Petitioner perforated the zone from 5084 to 5126 feet and received ample quantities of gas for its production facility. Petitioner also ran a cement bond log from the interval 5400 to 4600 feet and it was shown that there is solid cement from the gas interval at 5084 to 5126 to the interval where the water will be injected from 5600 down to 6072 feet. The cement will constitute a barrier so that there will be no water migration up on the outside of the casing.

18. Petitioner has successfully seated a Baker FH Hydrostatic Packer 5300, in the casing of the Fawn Creek Government Number 1 Well. This particular type of packer has been used in connection with water containing tritium. Any packer failure would be evidenced immediately because water would move up through the 1.9 inch casing of the gas production string and eventually the gas production would die. In the event of a leak, it would be necessary to pull the tubing strings and run a new packer after inhibiting the water or filling the casing with fresh water pumped down the 1.9 inch tube.

19. There is a dual hanger in the Fawn Creek Government Number $1 \mathrm{Well}$. The connection at which the tubing screws into the tubing hangers has been tested to $4300 \mathrm{psi}$ and was found to have no leaks. The joints between the $21 / 16^{\prime \prime}$ water injection tubing and the entire string have been pressure tested to 3,000 psi. The injection pressure through that tubing will be less than 1500 psi, probably 1000 psi. An injection pressure of 1500 psi would provide 3770 psi pressure at the point against the bottom of the packer. The gas zone has a bottom hole pressure of 1890 psi so the differential is less than 2000 psi. The packer should hold even when the differential is 7000-8000 psi. 
20. The calculated flooded radius from injected water during the flow period, if approximately 6500 barrels of water would be produced, in the sand interval from 5600 to $6072 \mathrm{feet,}$ where the net 8 and that has been opened is 150 feet, would be roughly a radius of 100 feet (less than an acre) even if only 20 feet of the 150 feet interval were taking water. If 20,000 to 24,000 barrels of water were produced and injected into the same area under a maximum 30-day injectivity test, the flooded area would be 190 to 195 feet in radius if only 20 feet of the interval took water. The water will be distributed reasonably uniformly around the well bore in an eccentric elipse approaching a circle. Water injectivity tests, performed by Petitioner in 1973 from roughly 5660 feet down below that point, which did not include the zone from 5600 to 5630 , showed that in excess of 3,000 barrels of water per day could be injected into these lower zones at 1500 psi. surface pressure. The rate of water production which Petitioner anticipates during the testing is 600 barrels a day.

21. Petitioner's understanding of the geological formations within a radius of at least ten miles from the Fawn Creek Government Number 1 Well is based upon all available geological information, with respect to that area, including an examination of all available well logs, drilling records, core analysis, and other physical data generally developed as part of a drilling program; including geophysical studies and reflection seismic studies; including a detailed study in the emplacement well area to determine if there were any faults and to check the authenticity and accuracy of previous geophysical surveys; and including examinations of the outcrops in the area.

22. In the area of Well No. RB-E-01 and the Fawn Creek Government Number 1 Well, the lowest or deepest geological aquifer or rock that contains sufficient permeability and porosity to have a reasonable amount of water is the B-aquifer located under the Mahogany Zone in the area of the Fawn Creek Government Number 1 Well. The bottom of this zone is approximately 1400 feet subsurface. There is no evidence of aquifers containing moving water below the B-aquifer.

23. The Mahogany Zone constitutes a barrier to water migration. Above the Mahogany Zone is a fractured shale sequence called the A-aquifer. Above the A-aquifer is the Evacuation Creek, which is shales and sandstones having very low capacity. And in the stream valleys there is a thin layer of alluvium which contains water. The alluvium, the A-aquifer and the $B$-aquifer constitute the viable aquifers in the area in question.

24. The bottom of the $B$-aquifer is approximately 5,000 feet above sea level. The top of the fractured zone of Well No. RB-E-0l is approximately 1,000 feet above sea level. The tritiated water will be injected into the Fawn Creek Government Number 1 Well at an interval from 500 to 1,000 feet above sea level. The re is approximately 3,000 feet of impermeable shale between the top of the zone into which water will be injected and the Baquifer. 
25. The $B$-aquifer, as the lowest and deepest area containing presently useable water, moves at a rate of about 35 feet per year. There is no source of withdrawal from the B-aquifer, near the location of the Fawn Creek Government Number 1 Well, for human use or irrigation or any other public use. Approximately three and one-half miles from this location there is a fault zone which may allow vertical migration of water which might result in water occurring in the alluvium, but at the rate of water movement in the $B$-aquifer it would take several hundred years for that water in the area of the Fawn Creek Government Number 1 Well to travel to this fault.

26. The A-aquifer has a velocity approximately ten times that of the B-aquifer. Water from the A-aquifer is being used within a distance of approximately four miles from Project Fio Blanco. The hydrologic report shows that the flow volume in the $A$-aquifer, the B-aquifer and the alluvium aquifer systems is so great that the dilution factor would prevent any hazard even if tritiated water could somehow mingle with the waters in these aquifers.

27. The water that will be produced during the test is connate water or fossil water, i. e., water deposited with the sediments or very close to the sediments in which it is currently found, which was laid down 50 to 60 million years ago and has remained localized in the sands during that time.

28. The water which will be injected into the Fawn Creek Government Number 1 Well to the same stratigraphic levels from which it came will have no present or foreseeable beneficial use and there is no reasonable probability that such water, while adversely affected, will mingle with or be tributary to beneficial, useable waters of the State of Colorado.

29. Petitioner has proven beyond a reasonable doubt that in disposing of radioactive water by injection into Fawn Creek Government Number 1 Well, as detailed in its "Project Rio Blanco Subsurface Water Disposal Application," dated June 11, 1973, as amended, that there will be no pollution resulting therefrom or that the pollution, if any, will be limited to waters in a specified limited area from which there is no risk of significant migration and that the disposal of the radioactive water is justified by public need.

October 15,1973

s/John Phillip Linn John Phillip Linn, Hearing Officer 
$\bullet$

$-86-$ 


\section{APPENDIX D- 1}

\section{BOTTOM HOLE PRESSURE AND TEMPERATURE DATA, WITH CORRESPONDING FLOW RATES FIRST PRODUCTION TEST}

November 14, 1973 to November 20, 1973

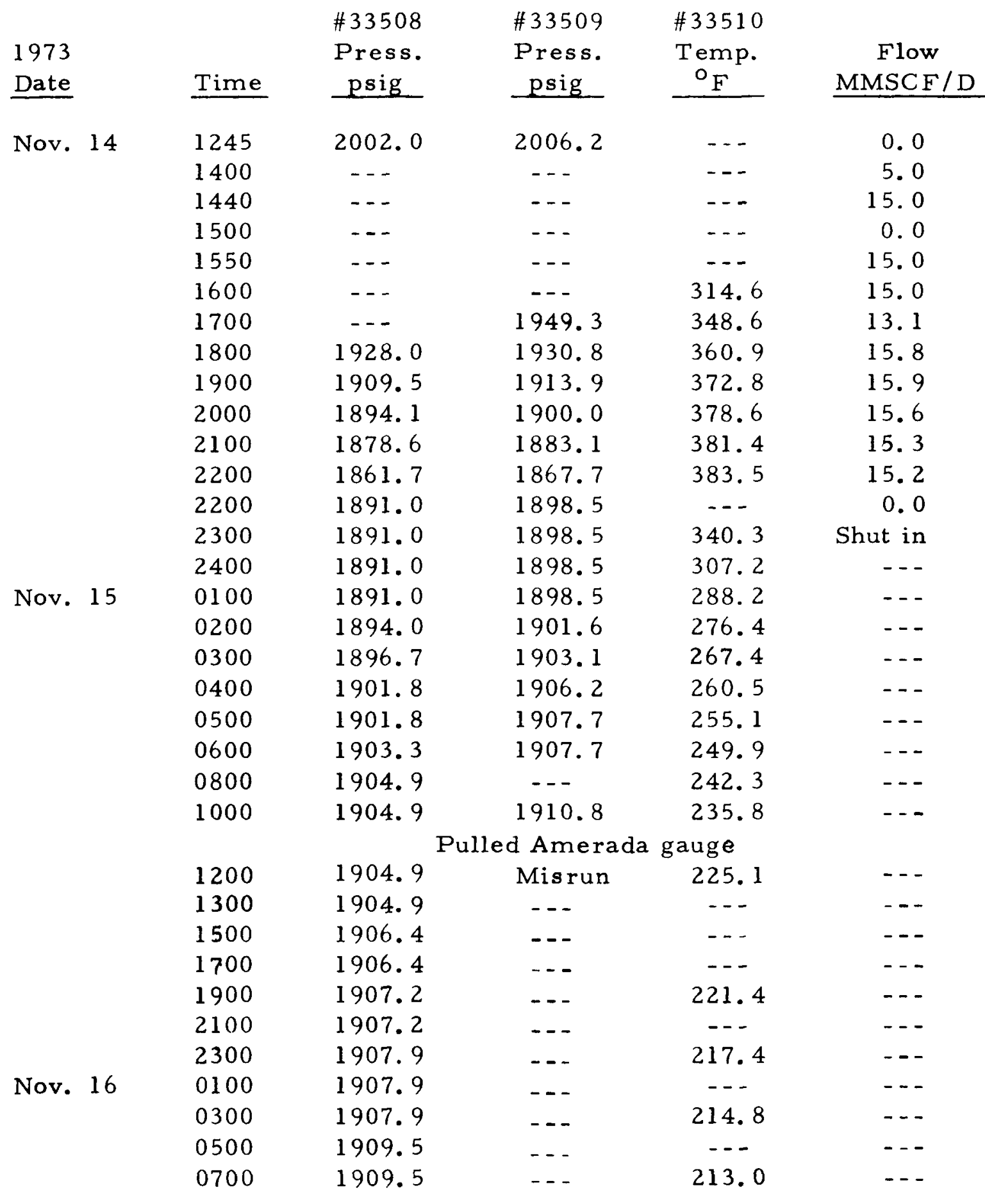


1973

Date

Nov. 16

1100
1130
1152
1215
1300
1500
1700
1900
2100
2300

Nov. $17 \quad 0100$

0300

0500

0700
\#33508

Press.

psig

1909.5

1909.5

1881.7

1895.6

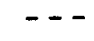

1880.2

1858.6

1838.5

$186 \hat{1} .9$

1796.9

1778.4

1758.3

1739.8

1719.8

1701.3
\#33509 \#33510

Press. Temp.

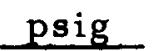

Misrun
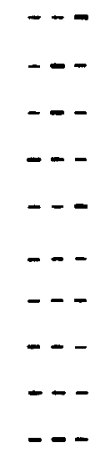

$-\cdot$

$--$

$-\frac{10}{20}$

$--$

Pulled bomb off bottom 0700 .
1973

Date

Nov. 17

Nov. 18

0100

0300

0500

0700

0900

\#33508

Press.

psig

1669.0

1664. 0

1653.0

1639.0

1626.0

1612.0

1599.0

1585.0

1572.0

1559.0

1547.0

1535.0

1522. 0

\#33509 \#23585

Press. Temp.

psig

1672.0

1664.0

1656.0

1641.0

1629.0

1615.0

1601.0

1588.0

1574.0

1562.0

1548.0

1535.0

1525.0

Elements out of hole 0900-1200

1200

1300

1500

1700

1900

2100

2300

Nov. 19
1503.8

1497.7

1483.8

1473.0

1460.7

1448.3

1434.4

1422.1

1409.8
1509.3

1503.1

1490.8

1478.5

1466.2

1453.9

1440.0

1429.3

1415.4
oF

414.7

414. 3

416.1

416.8

416.8

417.5

418.4

418.7

419.6

420.6

420.9

---
423.6
424.5
425.8
425.8
426.7
427.0
427.6
428.5

415.0
Flow

MMSC F/D

12. 0

Shut in

11.1

11.1

10.3

10.0

10.0

10.0

10.0

10.1

10.1

10.1

10.1
Flow

MMSCF/D

10.2

10.3

7. 9

8.0

8. 2

8. 4

8. 2

8. 2

8. 2

8. 3

8. 2

8.2

8. 0

8. 0

8. 0

8. 1

8.0

8. 0

8. 0

8.0

8.1

7. 9 
Date

\section{Pres8.}

Pres8.

Temp.

Nov. 19

Time

psig

peig

OF

$\begin{array}{ll}0500 & 1397.4 \\ 0700 & 1385.1 \\ 0900 & 1372.7 \\ 0930 & 1371.2\end{array}$

1403.1

429. 1

429.7

430.4

430.7

Flow

MMSCF/D

Ran instruments back into hole - on bottom at 1310 hours Temp. element \#23585 with 3 hours Hi Temp. clock - one press. element with spare 72 hours - Hi temp. clock other element with bed clock - All three 72 hours Hi temp. clocks malfunctioned when retrieved from hole - Ran ok to surface- / Change in temp. - Down hole temp. $431^{\circ} \mathrm{F}$, Surface $31^{\circ} \mathrm{F}$.

\begin{tabular}{|c|c|c|c|c|c|}
\hline Nov. 19 & 1400 & 1338.8 & Misrun & 430.7 & 8. 0 \\
\hline & 1600 & 1326.5 & Clock & $\ldots$ & 8.0 \\
\hline & 1800 & 1314.1 & Stopped & $\ldots$ & 8.0 \\
\hline & 2000 & 1301.8 & -- & -- & 8.0 \\
\hline & 2200 & 1290.9 & $\ldots$ & $\ldots$ & 8.0 \\
\hline & 2400 & 1277.1 & -- & $\ldots$ & 8.0 \\
\hline Nov. 20 & 0200 & 1264.8 & --- & $\ldots$ & 8.0 \\
\hline & 0400 & 1252.4 & -- & $\ldots$ & 8.0 \\
\hline & 0600 & 1241.6 & -- & $\cdots$ & 8.0 \\
\hline & 0800 & 1229.3 & --- & $\ldots$ & 8.1 \\
\hline & 1007 & 1218.5 & -- & 432.5 & 8.1 \\
\hline & 1007 & 1233.9 & $\ldots$ & - - & 0.0 \\
\hline
\end{tabular}


$\bullet$

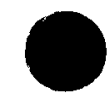

$-90-$ 


\section{APPENDIX D-2}

BOTTOM HOLE PRESSURE AND TEMPERATURE DATA FIRST PRESSURE BUILD-UP PERIOD

November 20, 1973 to January 28, 1974

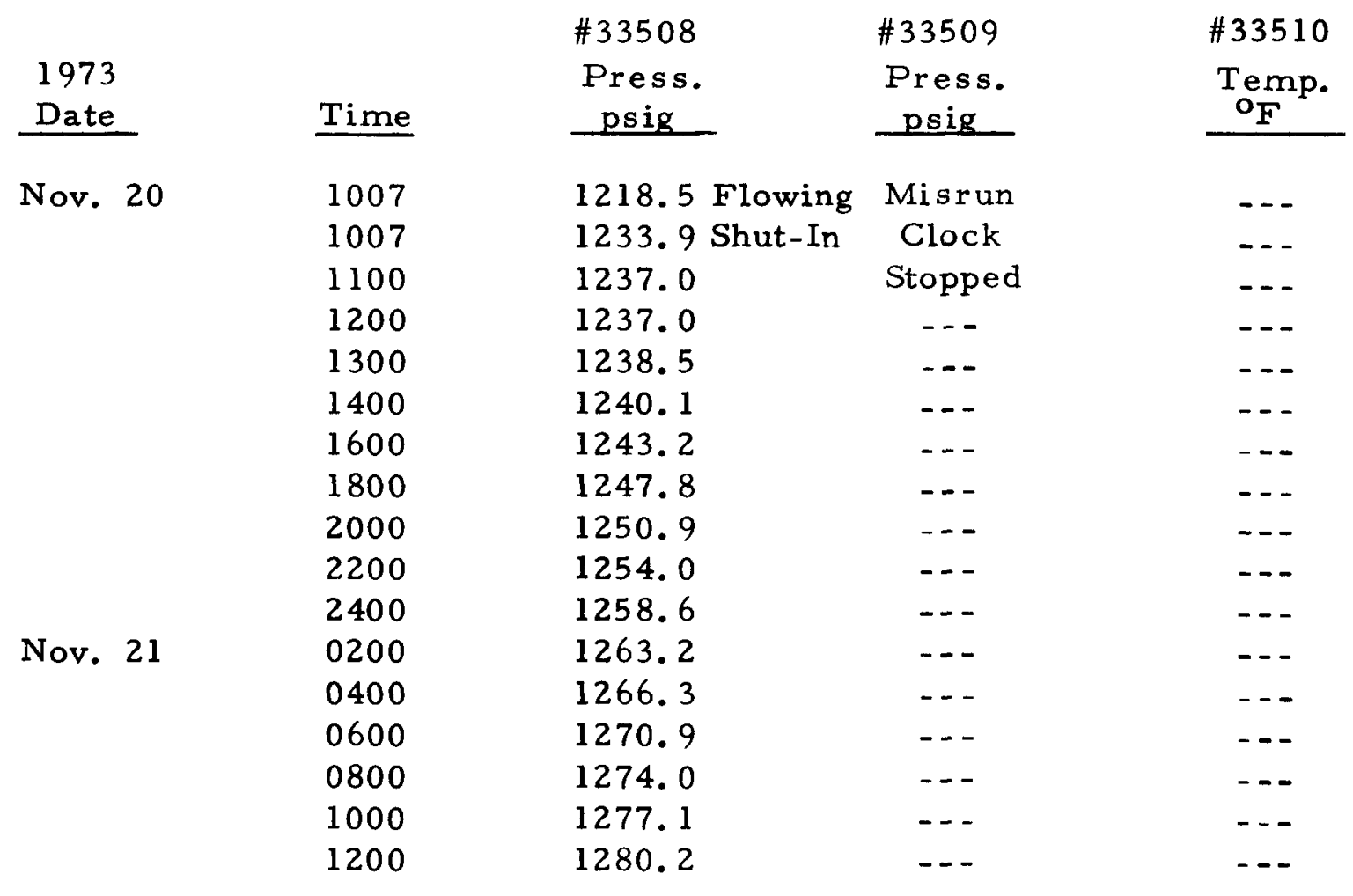

Start off bottom at 1210 hours Nov. 21 with Amerada gauges Back on bottom at $5160 \mathrm{ft} \mathrm{GL}$ at $1400 \mathrm{Nov} .21$.

\begin{tabular}{|c|c|c|c|c|}
\hline \multirow[t]{6}{*}{ Nov. 21} & 1400 & --- & 1275 & Mis run \\
\hline & 1600 & 1279 & 1277 & --- \\
\hline & 1800 & 1280 & 1280 & -- \\
\hline & 2000 & 1283 & 1283 & --- \\
\hline & 2200 & 1285 & 1285 & $\cdots$ \\
\hline & 2400 & 1288 & 1286 & --- \\
\hline \multirow[t]{12}{*}{ Nov. 22} & 0200 & 1290 & 1288 & $\ldots$ \\
\hline & 0400 & 1291 & 1291 & $\ldots$ \\
\hline & 0600 & 1294 & 1294 & --- \\
\hline & 0800 & 1296 & 1295 & -- \\
\hline & 1000 & 1297 & 1299 & $\ldots$ \\
\hline & 1200 & 1300 & 1300 &.- \\
\hline & 1400 & 1302 & 1302 & --- \\
\hline & 1600 & 1303 & 1305 & 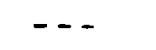 \\
\hline & 1800 & 1305 & 1306 & --- \\
\hline & 2000 & 1306 & 1308 & -- \\
\hline & 2200 & 1308 & 1311 & $\cdots$ \\
\hline & 2400 & 1310 & 1311 & $\cdots$ \\
\hline
\end{tabular}


1973

Date

Nov. 23

Nov. 24

Nov. 25

Nov. 26

Nov. 26

Nov. 27

Nov. 28
\# 33508

Press.

$\underline{\text { Time }}$

0200

0400

0600

0800

1000

1600

2200

0400

1000

1600

2200

0400

1000

1600

2200

0400

1000

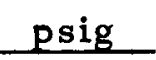

1311

1314

1316

1317

1320

1322

1327

1331

1334

1339

1340

1343

1348

1353

1354

1357

1360

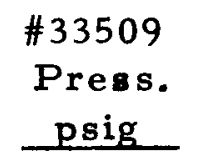

1314

1315

1317

1319

1322

1325

1326

1331

1334

1337

1339

1342

1345

1349

1351

1354

1357
\#33510

Temp.

${ }^{\circ} \mathrm{F}$
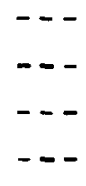

232.0

232.6 232.6 232. 2 231.8 231.2 230.8 230. 4 229. 8 229. 2 228.9 228.5

Reran instruments with 72-hour clocks

Reran to $5160 \mathrm{ft} \mathrm{GL}$ at 1130 Nov. 26.

$\begin{array}{lllll}\text { Nov. } 26 & 1200 & 1362 & 1365 & 223.0 \\ & 1800 & 1364 & 1366 & 225.3 \\ \text { Nov. } 27 & 2200 & 1365 & 1368 & 225.5 \\ & 0400 & 1368 & 1369 & 225.7 \\ & 1000 & 1371 & 1372 & 225.7 \\ & 1600 & 1373 & 1374 & 225.7 \\ \text { Nov. } 28 & 2200 & 1373 & 1374 & 225.5 \\ & 0400 & 1376 & 1377 & 225.3 \\ & 1000 & 1379 & 1380 & 225.3\end{array}$

Returned bombs to $5160 \mathrm{ft} \mathrm{GL}$ on bottom at Nov. 28 with 72 hour clocks.

$\begin{array}{ll}\text { Nov. 28 } & 1600 \\ & 2200 \\ \text { Nov. 29 } & 0400 \\ & 1000 \\ & 1600 \\ & 2200\end{array}$

Misrun
Clock
Malfunction

Misrun

1383

1385

1386

1388

1391

1391
---
222.3
222.8
223.0
223.4
223.4 


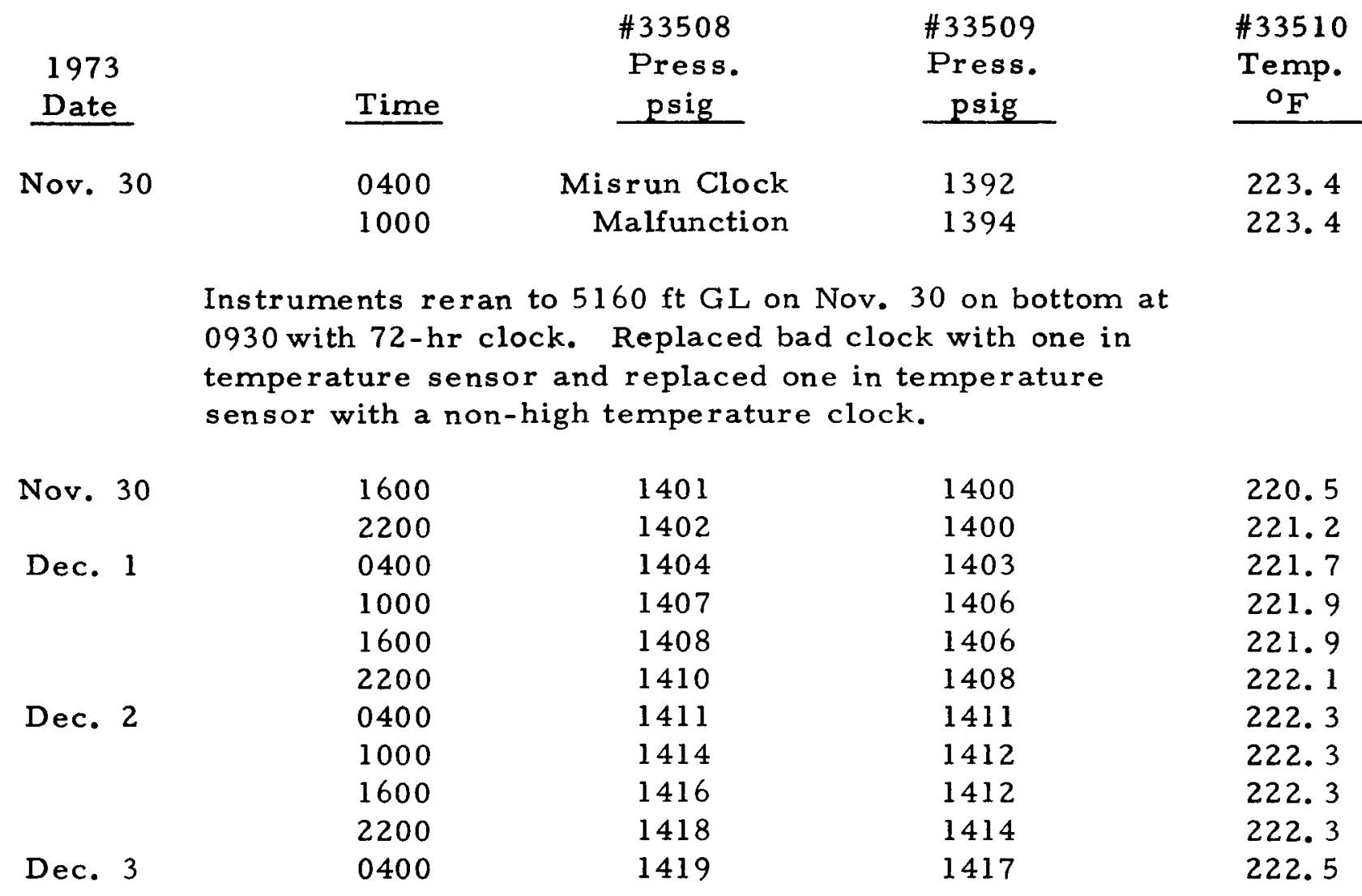

Reran instruments with 72 hour clocks to $5160 \mathrm{ft}$ GL on bottom at 1200 Dec. 3 .

$\begin{array}{ccccc}\text { Dec. } 3 & 1600 & 1422 & 1425 & 218.1 \\ \text { Dec. } 4 & 2200 & 1424 & 1428 & 219.2 \\ & 0400 & 1425 & 1429 & 219.7 \\ & 1000 & 1428 & 1431 & 220.1 \\ & 1600 & 1430 & 1432 & 220.3 \\ \text { Dec. } 5 & 2200 & 1430 & 1432 & 220.3 \\ & 0400 & 1431 & 1434 & 220.5 \\ & 1000 & 1433 & 1435 & 220.5 \\ & & & & \\ & \text { Reran instruments with } & 72 \text { hour clocks to } & 5160 \mathrm{ft} \mathrm{GL} & \\ \text { Dec. } 5 & \text { on bottom at 1130 Dec. } & 5 . & & 217.4 \\ & & & & 218.3 \\ \text { Dec. } 6 & 1600 & 1438 & 1437 & 219.0 \\ & 2200 & 1438 & 1439 & 219.7 \\ & 0400 & 1439 & 1440 & 219.9 \\ & 1000 & 1442 & 1443 & 220.1\end{array}$




\begin{tabular}{ccccc}
$\begin{array}{c}1973 \\
\text { Date }\end{array}$ & Time & $\begin{array}{c}\text { Press. } \\
\text { psig }\end{array}$ & $\begin{array}{c}\text { Press. } \\
\text { psig }\end{array}$ & $\begin{array}{c}\text { Temp. } \\
\text { OF }\end{array}$ \\
\cline { 2 - 3 } Dec. 7 & 0400 & 1445 & 1446 & 220.1 \\
& 1000 & 1447 & 1448 & 220.5
\end{tabular}

Reran instruments to $5160 \mathrm{ft} \mathrm{GL}$ on bottom at $1115 \mathrm{Dec} .7$. Replaced temp. element \#3351.0 with temp. element \#17592 to test for long response time in \#33510.

1973

Date

Dec. 7

Dec. 8

Dec. 9

Dec. 10

Dec. 10

Dec. 11

Dec. 12

Reran instruments to $5160 \mathrm{ft}$ GL on bottom at 1115 Dec. 10.

\begin{tabular}{c}
$\begin{array}{c}\# 3508 \\
\text { Press. } \\
\text { psig }\end{array}$ \\
\hline \\
1450 \\
1451 \\
1453 \\
1455 \\
1455 \\
1456 \\
1458 \\
1459 \\
1461 \\
1461 \\
1464 \\
1464
\end{tabular}

\#17592

Temp. ${ }^{\circ}$ F

195.7

195.5

195.4

195.2

195.0

195.0

194.8

194. 7

194.5

194.4

194.4

194.1

$\begin{array}{ccccc} & 1000 & 1468 & 1469 & 1971 \\ & 1600 & 1468 & 1471 & 194.1 \\ & 2200 & 1470 & 1472 & 194.0 \\ \text { Dec. } 12 & 0400 & -- & 1474 & 194.0 \\ & 1000 & \cdots & 1475 & 194.0\end{array}$

Reran instruments to $5160 \mathrm{ft} \mathrm{GL}$ on bottom at $1200 \mathrm{Dec} .12$.

$\begin{array}{ll}\text { Dec. } 12 & 1600 \\ & 2200 \\ \text { Dec. } 13 & 0400 \\ & 1000 \\ & 1600 \\ & 2200\end{array}$
1478
1479
1481
1482
1482
1484

1466

1468

1469

1471

1471

1474

1475
194.4

194. 4

194. 4

194. 1

194.0

194. 0

193.8 


\begin{tabular}{|c|c|c|c|c|}
\hline $\begin{array}{l}1973 \\
\text { Date } \\
\end{array}$ & Time & $\begin{array}{c}\# 33508 \\
\text { Press. } \\
\text { psig } \\
\end{array}$ & $\begin{array}{c}\# 33509 \\
\text { Press. } \\
\text { psig } \\
\end{array}$ & $\begin{array}{c}\# 17592 \\
\text { Temp. } \\
\text { of }_{\mathrm{F}} \\
\end{array}$ \\
\hline \multirow[t]{4}{*}{ Dec. 14} & 0400 & 1485 & 1486 & 193.4 \\
\hline & 1000 & 1485 & 1486 & 193.3 \\
\hline & 1600 & 1484 & 1486 & $\cdots$ \\
\hline & 2200 & 1485 & 1488 & $\ldots$ \\
\hline \multirow[t]{4}{*}{ Dec. 15} & 0400 & 1488 & 1489 & -- \\
\hline & 1000 & 1490 & 1491 & $\ldots$ \\
\hline & 1600 & 1490 & 1491 & $\ldots$ \\
\hline & 2200 & 1493 & 1492 & $\ldots$ \\
\hline \multirow[t]{4}{*}{ Dec. 16} & 0400 & 1495 & 1494 & $\ldots$ \\
\hline & 1000 & 1496 & 1495 & -- \\
\hline & 1600 & 1498 & 1495 &.- \\
\hline & 2200 & 1499 & 1497 & --- \\
\hline \multirow[t]{2}{*}{ Dec. 17} & 0400 & - - & 1497 & -- \\
\hline & 1000 & 1501 & 1499 & -- \\
\hline
\end{tabular}

Lost bombs in hole. No data until Dec. 22. Ordered new elements from Geophysical Research Corporation. Otis to retrieve old tools.

\section{3 \\ Date}

Dec. 22

Dec. 23

Dec. 24

Dec. 25

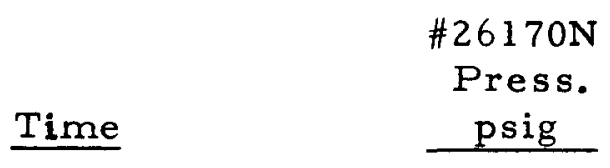

1600

2200

0400

1000

1600

2200

0400

1000

1600

2200

0400

1000
1532

1532

1533

1535

1535

1535

1536

1538

1538

1538

1539

1539
\#14379

Temp.

${ }^{\circ} \mathrm{F}$

193. 7

193. 7

193.7

193.3

192. 8

192.8

192. 4

191.9

191.5

191.5

191. 0

190.6

Reran instruments to $5160 \mathrm{ft}$ GL. On bottom at $1130 \mathrm{Dec} .26$.

Dec. 26

Dec. 27

Dec. 28
1600
0400
1600
0400

1600
1545

1546

1546

1549

1549
192. 4

194.6

195. 1

195. 1

195. 1 
$1973-74$

Date

Dec. 29
Time

0400
$\# 26170 \mathrm{~N}$

Press.

psig

1552
$\# 14379$

Temp.

${ }^{\circ} \mathbf{F}$

195.5

Reran instruments to $5160 \mathrm{ft}$ GL. On bottom at 1330 on Dec. 29.

$\begin{array}{lll}\text { Dec. } 29 & 1600 & 1555 \\ \text { Dec. } 30 & 0400 & 1550 \\ & 1600 & 1558 \\ \text { Dec. } 31 & 0400 & 1559 \\ & 1600 & 1561\end{array}$

Mis run Clock Malf unction
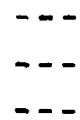

1974

Jan. 1 $0400 \quad 1562$

195.5

196.4

197.3

197.3

197.3

197.8

Change from Mountain Standard Time to Mountain Daylight Time on Jan. 7. Reran instruments to $5160 \mathrm{ft} \mathrm{GL.} \mathrm{On}$ bottom at $1330 \mathrm{Jan} .7$.

$\begin{array}{rrrr}\text { Jan. } 7 & 1600 & 1588 & 194.6 \\ \text { Jan. } 8 & 0400 & 1590 & 197.8 \\ & 1600 & 1591 & 198.7 \\ \text { Jan. } 9 & 0400 & 1594 & 199.6 \\ & 1200 & 1595 & 200.0\end{array}$

Reran instruments to $5160 \mathrm{ft}$ GL. On bottom at $1430 \mathrm{Jan}$. 9.

Jan. 9

Jan. 10

1600

0400

1600

Jan. 11
1595

1598

1600

1601
194.2 196.9

197.3

197.8

Reran instruments to $5160 \mathrm{ft} \mathrm{GL.} \mathrm{On} \mathrm{bottom} \mathrm{at} 1500 \mathrm{Jan} .11$. Changed packing on stuffing box. Pulled off approximately $210 \mathrm{ft}$ of wire on wireline unit. 


\begin{tabular}{|c|c|c|c|}
\hline $\begin{array}{l}1974 \\
\text { Date }\end{array}$ & Time & $\begin{array}{c}\# 26170 \mathrm{~N} \\
\text { Press. } \\
\text { psig } \\
\end{array}$ & $\begin{array}{c}\# 14379 \\
\text { Temp. } \\
\text { of }^{2}\end{array}$ \\
\hline Jan. 11 & 1600 & 1603 & 197.8 \\
\hline \multirow[t]{2}{*}{ Jan. 12} & 0400 & 1606 & 199.6 \\
\hline & 1600 & 1606 & 199.6 \\
\hline \multirow[t]{2}{*}{ Jan. 13} & 0400 & 1607 & 199.6 \\
\hline & 1600 & 1607 & 198.7 \\
\hline Jan. 14 & 0400 & 1610 & 198.7 \\
\hline
\end{tabular}

Installed tool trap between lubricator and BOP. Reran instruments to $5160 \mathrm{ft}$ GL. On bottom at $1545 \mathrm{Jan} .14$.

$\begin{array}{llll}\text { Jan. } 14 & 1600 & 1608 & 196.0 \\ \text { Jan. } 15 & 0400 & 1611 & 200.0 \\ & 1600 & 1613 & 200.6 \\ \text { Jan. } 16 & 0400 & 1614 & 201.0\end{array}$

Reran instruments to $5160 \mathrm{ft} \mathrm{GL.} \mathrm{On} \mathrm{bottom} \mathrm{at} 1445 \mathrm{Jan} .16$.

$\begin{array}{rrrr}\text { Jan. } 16 & 1600 & 1614 & 196.4 \\ \text { Jan. } 17 & 0400 & 1616 & 198.7 \\ & 1600 & 1617 & 200.0 \\ \text { Jan. } 18 & 0400 & 1619 & 200.3\end{array}$

Reran instruments to $5160 \mathrm{ft} \mathrm{GL.} \mathrm{On} \mathrm{bottom} \mathrm{at} 1330 \mathrm{Jan} .18$.

$\begin{array}{llll}\text { Jan. } 18 & 1600 & 1621 & 195.5 \\ \text { Jan. } 19 & 0400 & 1623 & 197.3 \\ & 1600 & 1623 & 197.8 \\ \text { Jan. } 20 & 0400 & 1624 & 197.8 \\ & 1600 & 1624 & 197.8 \\ \text { Jan. } 21 & 0400 & 1626 & 198.7\end{array}$

Reran instruments to $5160 \mathrm{ft} \mathrm{GL.} \mathrm{On} \mathrm{bottom} \mathrm{at} 1430 \mathrm{Jan} .21$.

$\begin{array}{lllr}\text { Jan. } 21 & 1600 & 1629 & 194.6 \\ \text { Jan. } 22 & 0400 & 1630 & 197.8 \\ & 1600 & 1632 & 198.7 \\ \text { Jan. } 23 & 0400 & 1633 & 199.6\end{array}$

Reran temperature element \#14379, pressure element \#26170N, and pressure element \#34225 with 3 -hour clocks for survey. 
1974
Date

Jan. 23

$\begin{array}{ll}1400 & 5160 \\ 1410 & 5200 \\ 1421 & 5400 \\ 1432 & 5600 \\ 1443 & 5625 \\ 1453 & 5650 \\ 1504 & 5675 \\ 1520 & 5685 \\ 1530 & 5695 \\ 1540 & 5705\end{array}$

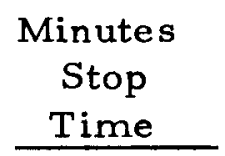

1523

1546

1553

1558

1604

1610

1620

1625

1630

1635

1645

1650
Depth

From

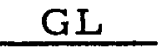

5160

5215

5315

5415

5515

5565

5615

5635

5655

5675

5685

5695

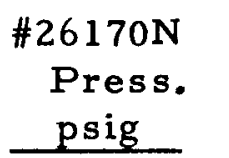

15

5

5

5

5

10

5

5

5

10

5

5

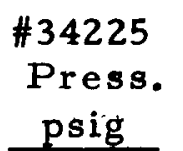

1633

1636

1639

1643

1646

1649

*1645

$* 1636$

*1642

1650

*1652

*1653
\#14379

Temp.

${ }^{o_{F}}$

192. 8

195.5

197.3

199. 1

201.6

209.0

320.7

389.9

Off

Scale

1658

1659

1660

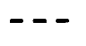

*Temperature affected.

Jan. 24

Jan. 24

Reran instruments with 3-hour clocks \#23585 (400 $\left.\mathrm{F}-650^{\circ} \mathrm{F}\right)$. temperature survey.

1540

Tagged TD at $5707 \mathrm{ft} \mathrm{GL.}$

$\begin{array}{rr}10 & 1636 \\ 10 & 1637 \\ 10 & 1645 \\ 10 & 1649 \\ 10 & * 1640 \\ 10 & * 1649 \\ 15 & * 1655 \\ 10 & * 1655 \\ 10 & * 1656 \\ 5 & * 1656\end{array}$

1630

1632

1640

1645

1648

1650

1658

1658

1658

1658

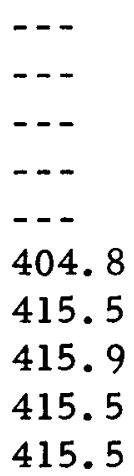

415.5

*Temperature affected.

Jan. 25 Reran temperature element \#34226 (150 ${ }^{\circ} \mathrm{F}-400$ o F). Pressure element \#33508 (3000 psi), pressure element \#34225 (3000 psi), with 72 -hour clocks to $5160 \mathrm{ft} \mathrm{GL}$. On bottom at 1330 . 


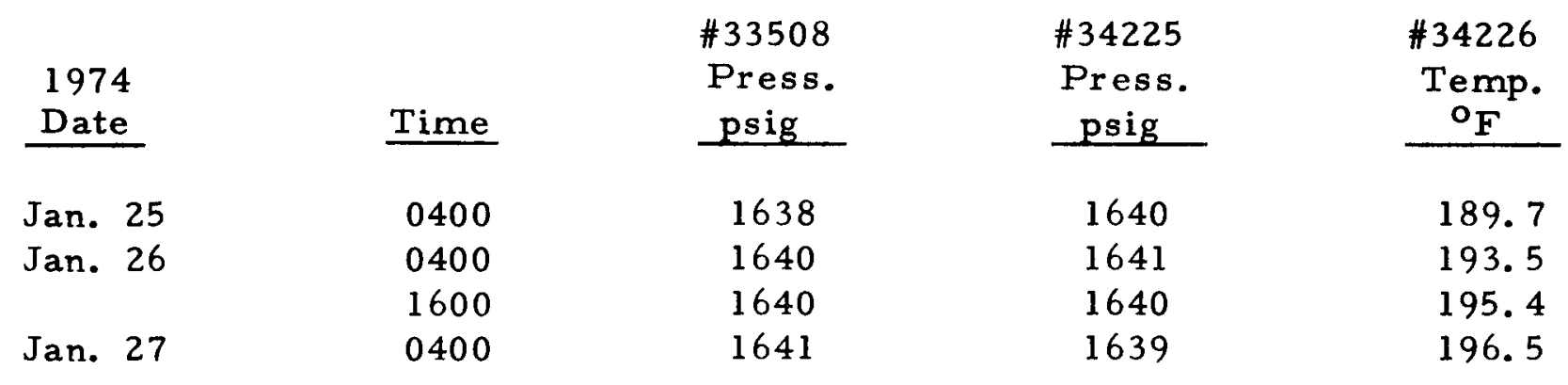

Jan. 27 Reran instruments with new high range tempe rature element \#23585 $\left(400^{\circ} \mathrm{F}-650^{\circ} \mathrm{F}\right)$ to $\mathrm{GL}$ depth of $5650 \mathrm{ft}$ for 3 hours, at 1200 hours, $5700 \mathrm{ft} \mathrm{GL}$ for 3 hours at 1500 then back to $5160 \mathrm{ft} \mathrm{GL}$ at 1800 . Will pull again for readings Jan. 28 a. m.

1974

\#33508

Date

Time

Press.

psig _

\#34225

\#23585

Date

Jan. 27

1500

1670

Press.

(5650'GL)

1800

1671

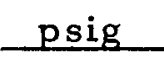

Temp.

$\left(5700^{\prime} \mathrm{GL}\right)$

Jan. 28

0400

1645

1660

408. 9

(5160'GL)

1661

414. 1

1630

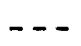

Reran same instruments to $5160 \mathrm{ft} \mathrm{GL}$. On bottom at $1030 \mathrm{Jan} .28$.

Jan. 28

$$
\begin{aligned}
& 1200 \\
& 1300 \\
& 1400 \\
& 1500
\end{aligned}
$$
1652
1652
1652
1652

1654
1654
1654
1654

-- 
$-100-$ 
BOTTOM HOLE PRESSURE AND TEMPERA TURE DATA

WITH CORRESPONDING F LOW RATES

SECOND PRODUCTION TEST

January 28 - February 15, 1974

1974

Date

Jan. 28

Jan. 29

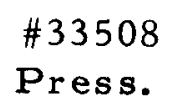

$\underline{\text { Time }}$

1200

1300

1400

1500

1535

1600

1625

1625

1700

1800

1900

2000

2100

2200

2300

2400

0100

0200

0300

0400

0500

0600

0700

0800

1000

1100

1200

1300

1400

1500

1505

1510

1600

1700

1800

1900

\section{Press.}

psig

1652

1652

1652

1652

Startup

1632

1631

1636

1625

1619

1614

1608

1600

1594

1588

1582

1575

1568

1561

1557

1550

1544

1538

1532

1514.6

1509.9

1502.1

1497.4

1491.2

1488.0

1492.7

1484.9

1478.7

1474.0

1467.8

\section{\#34225}

Press.

psig

1654

1654

1654

1654

---

1634

1634

1638

1632

1626

1619

1611

1605

1599

1592

1586

1579

1573

1565

1560

1552

1547

1539

1535

\section{7}

1516.3

1509.9

1503.5

1497.1

1495.5

1498.7

1492.3

1485.9

1479.5

1473.1
\#23585

Temp. Flow

oF

MMSCF/D

Below scale

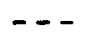

$--$

$-\cdot$

-

$--$

$---$

401.9

403.7

405.6

407.4

410.0

411.1

412.6

414.1

414.8

415.5

416.3

417.0

417.8

418.1

418.5

419.4

425.3

425.3

425.6

425.9

426.3

-..

417.8

426.3

426.6

426.9

427.5
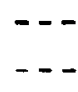

--

-..

6.5

-..

6.0

0.0

6. 8

6.2

6.1

6.8

6. 0

6.2

6.0

6.3

6.2

6.1

6.0

6. 0

5. 8

5. 7

5. 8

5. 9

6.1

6.2

6.2

6.4

6.4

6.3

-.-

-.

6.3

6.4

6.2

6.2 
\begin{tabular}{l}
1974 \\
Date \\
\hline
\end{tabular}

\#33508

Jan. 29

Jan. 30

Jan. 31

\begin{tabular}{|c|c|c|}
\hline Time & $\begin{array}{c}\# 33508 \\
\text { Press. } \\
\text { psig }\end{array}$ & $\begin{array}{c}\# 34225 \\
\text { Press. } \\
\text { psig }\end{array}$ \\
\hline 2000 & 1461.5 & 1468.3 \\
\hline 2100 & 1455.3 & 1460.3 \\
\hline 2200 & 1449.1 & 1455.5 \\
\hline 2300 & 1442.8 & 1449.1 \\
\hline 2400 & 1436.6 & 1447.7 \\
\hline 0100 & 1431.9 & 1437.9 \\
\hline 0200 & 1425.7 & 1429.9 \\
\hline 0300 & 1419.4 & 1425.2 \\
\hline 0400 & 1414.7 & 1420.4 \\
\hline 0500 & 1408.5 & 1412.4 \\
\hline 0600 & 1403.8 & 1407.6 \\
\hline 0700 & 1397.6 & 1401.2 \\
\hline 0800 & 1389.8 & 1393.2 \\
\hline 1200 & 1377.2 & 1374.2 \\
\hline 1400 & -- & - - \\
\hline 1600 & -- & -- \\
\hline 1800 & $\ldots$ & $\ldots$ \\
\hline 2000 & -- & -- \\
\hline 2200 & -- & -- \\
\hline 2400 & --- & -- \\
\hline 0200 & -- & --- \\
\hline 0400 & -- & $-\cdots$ \\
\hline 0600 & -- & -- \\
\hline 0800 & 1257.6 & 1268.1 \\
\hline
\end{tabular}

\#23585

Temp.

${ }^{\circ} \mathrm{F}$

Flow

MMSCF/D

427.8

6.2

428.4

428. 7

429.7

430.0

430.0

430.6

$430: 6$

431.2

431.5

431.5

431.8

432.8

436.7

436.7

436.7

436.9

437.2

437.5

437.7

437.7

438.0

438.3

438.5
6. 2

6.2

6.1

6.1

6.1

6.1

6. 0

6. 0

5. 9

5. 9

5. 9

6.5

6. 3

6.2

6.2

6.2

6.2

6.2

6.2

6.2

6.2

6. 2

6.2

Re-ran instruments to $5160 \mathrm{ft} \mathrm{GL.} \mathrm{Reached} \mathrm{that} \mathrm{depth}$ at 1130. Neither clock in press. instruments ran.

Replaced clock in \#34225 with 3-hour high temperature clock and replaced clock in \#33508 with 72-hour high temperature clock. 3-hour clock loaded at 1050.

$\begin{array}{cccccc} & 1200 & 1232 & --- & -- & 6.2 \\ 1300 & 1229 & --- & -- & 6.1 \\ 1400 & 1221 & 1222 & 442.5 & 6.1 \\ 1600 & 3-\text { hour } & 1209 & 442.5 & 6.1 \\ & 1800 & \text { clock } & 1197 & 442.8 & 6.3 \\ & 2000 & \text { only } & 1186 & 443.0 & 6.3 \\ & 2200 & -- & 1173 & 443.3 & --- \\ & 2400 & -- & 1162 & 443.6 & 6.0 \\ & 0200 & -- & 1152 & 443.8 & 6.0 \\ & 0400 & -- & 1141 & 444.1 & 5.9 \\ & 0600 & -- & 1128 & 444.4 & 6.0 \\ & 0800 & -- & 1117 & 444.6 & 6.3\end{array}$

Re-ran instruments to $5160 \mathrm{ft} \mathrm{GL.} \mathrm{Used} \mathrm{72-hour} \mathrm{clocks}$ on all instruments. Reached $5160 \mathrm{ft} \mathrm{GL}$ at 1115, Feb. 1 . Well shut in 0945 to 1153 , Feb. 1. 


\begin{tabular}{|c|c|c|c|c|c|}
\hline $\begin{array}{l}1974 \\
\text { Date }\end{array}$ & Time & $\begin{array}{c}\# 33508 \\
\text { Press. } \\
\text { psig }\end{array}$ & $\begin{array}{c}\# 34225 \\
\text { Press. } \\
\text { psig }\end{array}$ & $\begin{array}{c}\# 23585 \\
\text { Temp. } \\
\mathrm{o}_{\mathrm{F}} \\
\end{array}$ & $\begin{array}{c}\text { Flow } \\
\text { MMSCF/D }\end{array}$ \\
\hline \multirow[t]{8}{*}{ Feb. 1} & 1400 & 1119 & 1118 & 442.5 & -- \\
\hline & 1600 & 1116 & 1114 & 443.3 & 4. 3 \\
\hline & 1700 & -- & $\ldots$ & -- & 4.2 \\
\hline & 1800 & 1109 & 1107 & 443.8 &.-- \\
\hline & 2000 & 1101 & 1099 & 444.4 & 4. 2 \\
\hline & 2125 & 1090.4 & 1086.2 & - - & 4.2 \\
\hline & 2125 & 1098.3 & 1094.2 & 444.6 & 0.0 \\
\hline & 2400 & Startup & -- & -- & 4.2 \\
\hline \multirow[t]{4}{*}{ Feb. 2} & 0200 & 1086 & 1081 & 444.1 & 4.2 \\
\hline & 0400 & 1076 & 1075 & 444.6 & 4. 0 \\
\hline & 0600 & 1070 & 1067 & 445.2 & 3.8 \\
\hline & 0800 & 1062 & 1059 & 445.4 & 4. $2 *$ \\
\hline
\end{tabular}

Re-ran instruments to $5160^{\prime} \mathrm{GL}$. On bottom at $1000, \mathrm{Feb}$. 2. Downhole flow rate at shut-in approximately 4.2 MMSCF/D gas + 3.4 MMSCF water vapor. Well shut in 2125 to 2400, Feb. 1 .

*Starting at 0800, Feb. 2, flow data are averages of the previous 4 hours.

\begin{tabular}{|c|c|c|c|c|c|}
\hline $\begin{array}{l}1974 \\
\text { Date } \\
\end{array}$ & Time & $\begin{array}{c}\# 33508 \\
\text { Press. } \\
\text { psig. } \\
\end{array}$ & $\begin{array}{c}\# 34225 \\
\text { Press. } \\
\text { psig. } \\
\end{array}$ & $\begin{array}{c}\# 23585 \\
\text { Temp. } \\
o_{F} \\
\end{array}$ & $\begin{array}{c}\text { Preceding } \\
\text { 4-hr. Ave. } \\
\text { Flow } \\
\text { MMSCF/D }\end{array}$ \\
\hline & 1200 & 1051.1 & 1049.8 & 449.1 & 4.4 \\
\hline & 1400 & 1043.2 & 1041.7 & 449.1 & $\ldots$ \\
\hline & 1600 & 1035.4 & 1035.3 & 449.1 & 4. 4 \\
\hline & 1800 & 1027.5 & 1025.6 & 449.1 & $\ldots$ \\
\hline & 2000 & 1019.6 & 1019.2 & 448.7 & 4.4 \\
\hline & 2200 & 1011.8 & 1011.1 & 448.2 & $\ldots$ \\
\hline & 2400 & 1005.5 & 1003.1 & 448.2 & 4.4 \\
\hline \multirow[t]{4}{*}{ Feb. 3} & 0200 & 997.6 & 995.0 & 448.2 &.- \\
\hline & 0400 & 989.7 & 987.0 & 448.2 & 4. 4 \\
\hline & 0600 & 981.9 & 978.9 & 448.2 & $\ldots$ \\
\hline & 0800 & 974.0 & 972.5 & 448.0 & 4. 4 \\
\hline
\end{tabular}

Re-ran instruments to $5160 \mathrm{ft}$ GL. Reached depth at 1030 ,

Feb. 3. Exchanged 72 -hour clock in \#34225 with 24-hour clock.

$\begin{array}{lllll}1200 & 955.1 & 958.0 & 452.5 & 4.3 \\ 1400 & 945.3 & 950.0 & 452.3 & -- \\ 1600 & 937.8 & 941.9 & 451.8 & 4.5 \\ 1800 & 929.9 & 933.9 & 451.6 & -. \\ 2000 & 922.1 & 925.8 & 451.4 & 4.4 \\ 2200 & 914.2 & 917.8 & 451.1 & --- \\ 2400 & 906.3 & 909.7 & 450.9 & 4.4\end{array}$




\begin{tabular}{|c|c|c|c|c|c|}
\hline & & & & & Preceding \\
\hline & & \#33508 & $\# 34225$ & $\# 24585$ & 4-hr. Ave. \\
\hline $\begin{array}{l}1974 \\
\text { Date }\end{array}$ & Time & $\begin{array}{c}\text { Press. } \\
\text { psig. }\end{array}$ & $\begin{array}{c}\text { Press. } \\
\text { psig. }\end{array}$ & $\begin{array}{l}\text { Temp. } \\
\mathrm{o}_{\mathrm{F}} \\
\end{array}$ & $\begin{array}{c}\text { Flow } \\
\text { MMSCF/D } \\
\end{array}$ \\
\hline Feb. 4 & 0200 & 900.0 & 901.7 & 450.7 & --- \\
\hline & 0400 & 892.2 & 893.6 & 450.7 & 4. 2 \\
\hline & 0600 & 884.3 & 885.6 & 450.5 & -- \\
\hline & 0800 & 874.9 & 875.9 & 449.8 & 4.2 \\
\hline
\end{tabular}

Re-ran instruments to $5160 \mathrm{ft}$ GL. On bottom at 1000 Feb. 4. Exchanged bad 72-hour clock in temperature element with 24-hour clock.

\begin{tabular}{|c|c|c|c|c|c|}
\hline & 1000 & 868.8 & -- & --- & --- \\
\hline & 1050 & 870.4 & 870.5 & -- & -- \\
\hline & 1050 & 881.5 & 881.9 & --- & 0.0 \\
\hline & 1200 & 886.2 & 883.5 & --- & -- \\
\hline & 1300 & -- & --- & -- & 4.6 \\
\hline & 1400 & 864.1 & 867.3 & 450.0 & --- \\
\hline & 1600 & 857.7 & 859.2 & 450.2 & 4.6 \\
\hline & 1800 & 849.8 & 851.1 & 450.2 & -- \\
\hline & 2000 & 841.9 & 844.6 & 450.2 & 4.5 \\
\hline & 2200 & 837.1 & 838.2 & 450.2 & -- \\
\hline & 2400 & 829.2 & 831.7 & 450.2 & 4. 1 \\
\hline Feb. 5 & 0200 & 822.9 & 822.0 & 450.0 & -- \\
\hline & 0400 & 815.0 & 815.5 & 449.8 & 4.0 \\
\hline & 0600 & 808.7 & 807.4 & 449.8 & -- \\
\hline & 0800 & 800.8 & 801.0 & 449.6 & 4. 0 \\
\hline
\end{tabular}

Re-ran instruments to $5160 \mathrm{ft} \mathrm{GL}$. On bottom at 1000 Feb. 5. Well shut in 0945 to 0955 and 1050 to 1210 .

$\begin{array}{cccccc} & 1200 & 786.5 & 791.3 & 450.7 & 4.0 \\ & 1400 & 778.6 & 784.8 & 450.7 & --- \\ & 1600 & 772.3 & 778.3 & 450.7 & 3.9 \\ 1800 & 765.9 & 771.8 & 450.5 & --- \\ & 2000 & 761.2 & 765.4 & 450.5 & 3.8 \\ & 2200 & 753.3 & 758.9 & 450.2 & --- \\ \text { Feb. } 6 & 748.5 & 752.4 & 450.0 & 3.8 \\ & 2400 & 742.2 & 745.9 & 450.0 & --- \\ & 0200 & 735.9 & 737.8 & 449.8 & 3.7 \\ & 0400 & 728.0 & 731.4 & 449.6 & --- \\ & 0600 & 721.6 & 724.9 & 449.3 & 3.7\end{array}$

Re-ran instruments to $5160 \mathrm{ft}$ GL. Reached depth at 1030 , Feb. 6. Replaced bad clock in \#23585 with 72 -hour clock. 
1974

Date

Feb. 6

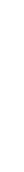

Feb. 7

Feb. 8

\section{\#33508}

Press.

Time

1200

1400

1600

1800

2000

2200

2400

0200

0400

0600

0800

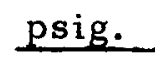

Misrun
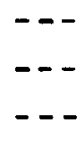

$\cdots$

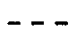

-..

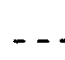

$--$

$-$

- -

\begin{abstract}
\# 34225
\end{abstract}
Press.

psig.

712.2

708. 9

704.1

697.6

695.9

694.3

689.4

682.9

679.7

676.4

671.5
Preceding

4-hr. Ave. Flow

MMSCF/D

3.6

446.8

446.8

446.8

446.2

445. 7

446.0

445.7

445. 4

445.4

445. 4

445.2
3.6

$--$

3.1

-.-

3. 0

- -

2. 9

- -

2. 9

Re-ran instruments to $5160 \mathrm{ft}$ GL. Reached depth at 1020 , Feb. 7 .

$\begin{array}{cccccc} & 1200 & 660.5 & 666.7 & 447.3 & 2.8 \\ & 1400 & 655.7 & 663.4 & 447.3 & --- \\ & 1600 & 652.5 & 660.2 & 447.3 & 2.9 \\ & 1800 & 647.7 & 655.3 & 447.0 & -- \\ & 2000 & 644.6 & 650.4 & 446.5 & 2.8 \\ & 2200 & 639.8 & 647.2 & 446.5 & --- \\ \text { Feb. } 8 & 2400 & 636.6 & 642.3 & 446.2 & 2.8 \\ & 0200 & 631.8 & 637.4 & 446.0 & --- \\ & 0400 & 628.6 & 632.5 & 445.7 & 2.7 \\ & 0600 & 625.5 & 627.6 & 445.7 & 2.7\end{array}$

Re-ran instruments to $5160 \mathrm{ft}$ GL. On bottom at 1045, Feb. 8 .

$\begin{array}{lllll}1200 & 623.9 & 622.8 & 447.3 & 2.1 \\ 1400 & 620.7 & 619.5 & 446.8 & -\ldots \\ 1600 & 619.1 & 617.9 & 446.0 & 2.2 \\ 1800 & 615.9 & 616.3 & 445.7 & -\ldots \\ 2000 & 614.3 & 614.6 & 445.4 & 2.2 \\ 2200 & 612.7 & 611.4 & 445.7 & -\ldots \\ 2400 & 609.5 & 608.1 & 445.2 & 2.1 \\ 0200 & 606.4 & 604.9 & 445.4 & -\ldots \\ 0400 & 603.2 & 603.2 & 445.4 & 2.1 \\ 0600 & 600.0 & 601.6 & 445.4 & -.- \\ 0800 & 596.8 & 598.4 & 445.4 & 2.1\end{array}$

Re-ran instruments to $5160 \mathrm{ft} \mathrm{GL.} \mathrm{On} \mathrm{bottom} \mathrm{at} 1115$, Feb. 9. 
1974

Date

Feb. 9

Feb. 10

0200

0400

0600

0800
Press.

psig

590.5

588.9

587.3

584.1

580.9

579.3

576.1

569.8

568.2

565.0

563.4

\section{\#34225}

Press.

\#24585

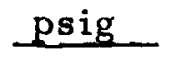

592.0

590.2

587.0

585.4

582.1

580.5

577.2

572.4

569.1

565.8

564. 2

444. 4

445. 7

445.4

445. 2

445.7

445.7

445.2

444.9

444. 9

444. 4

444. 4
Preceding

4-hr. Ave.

Flow

MMSCF/D

2. 2
-.-

2. 2

- -

2. 2

$--$.

2.2

- -

2. 1

$---$

2. 1

Re-ran instruments to $5160 \mathrm{ft}$ GL. Reached bottom at 1015 , Feb. 10.

$\begin{array}{cccccc} & 1200 & 552.3 & \text { Misrun } & 444.4 & 2.4 \\ & 1400 & 549.1 & -- & 444.1 & -- \\ & 1600 & 547.5 & -- & 442.8 & 2.3 \\ & 1800 & 544.3 & -- & 443.0 & -- \\ & 2000 & 541.1 & -- & 442.5 & 2.3 \\ & 2200 & 537.9 & -- & 442.5 & -- \\ \text { Feb. } 11 & 2400 & 534.7 & -- & 442.2 & 2.3 \\ & 0200 & 533.2 & -- & 442.0 & -- \\ & 0400 & 530.0 & --- & 441.7 & 2.2 \\ & 0600 & 525.2 & -- & 441.4 & -- \\ & 0800 & 522.0 & --- & 441.2 & 2.2\end{array}$

Re-ran instruments to $5160 \mathrm{ft}$ GL. On bottom at 1030, Feb. 11 . Replaced bad clock in \#34225.

$\begin{array}{cccccc} & 1200 & 520.4 & 520.3 & 442.8 & 2.1 \\ & 1400 & 517.3 & 517.1 & 443.0 & -- \\ & 1600 & 514.1 & 515.4 & 442.5 & 2.1 \\ & 1800 & 512.5 & 512.2 & 442.2 & -- \\ & 2000 & 509.3 & 510.6 & 442.0 & 2.1 \\ & 2200 & 506.1 & 507.3 & 442.0 & -- \\ \text { Feb. } 12 & 2400 & 502.9 & 505.7 & 441.7 & 2.0 \\ & 0200 & 501.3 & 502.4 & 441.4 & -- \\ & 0400 & 498.1 & 500.8 & 441.4 & 2.0 \\ & 0600 & 495.0 & 499.2 & 441.2 & -- \\ & 0800 & 493.4 & 497.6 & 442.2 & 2.0\end{array}$

Re-ran instruments to $5160 \mathrm{ft} \mathrm{GL.} \mathrm{On} \mathrm{bottom} \mathrm{at} \mathrm{1045,} \mathrm{Feb.} 12$. 


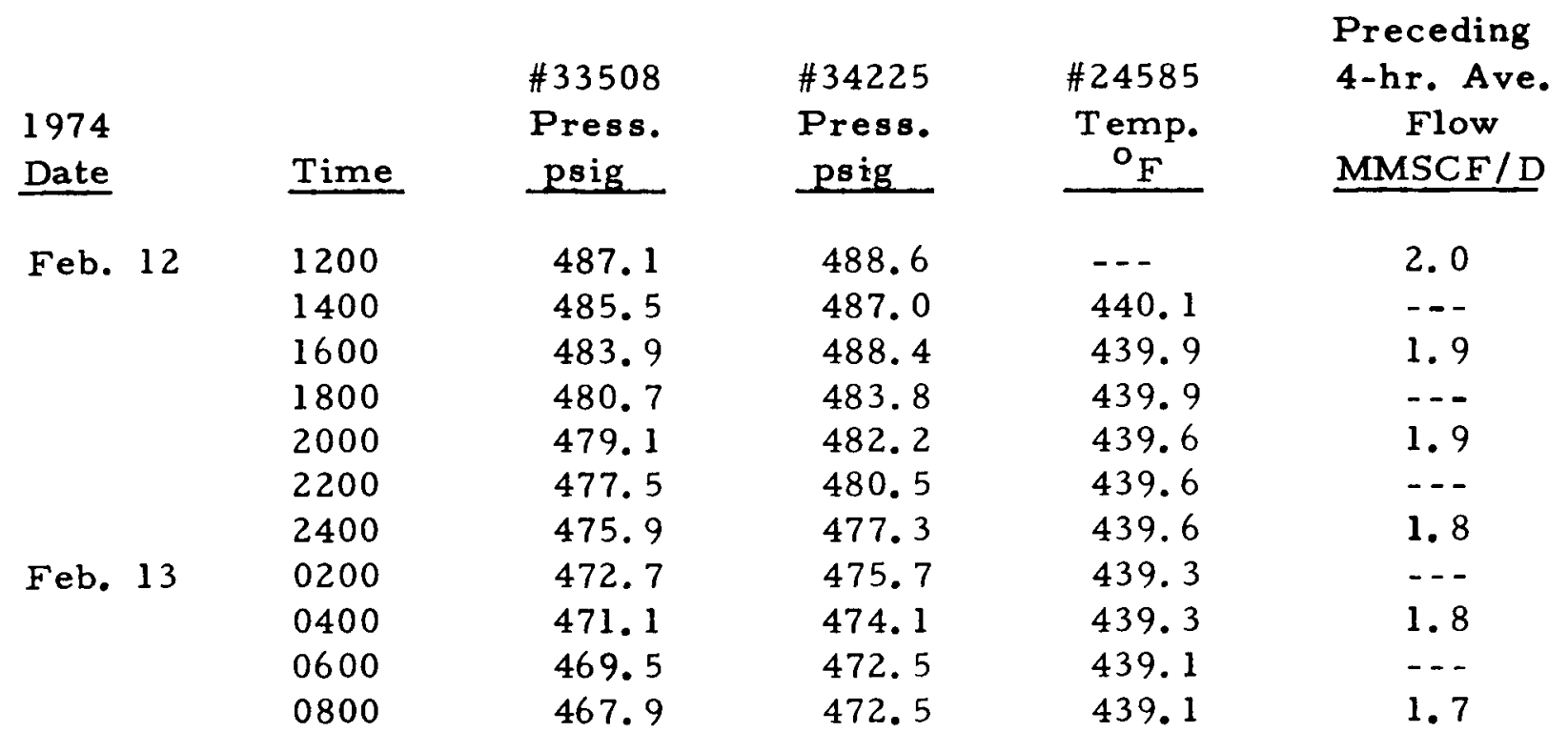

Re-ran instruments to $5160 \mathrm{ft}$ GL. On bottom at 1000, Fe. 13.

$\begin{array}{cccccc}1200 & 466.3 & 469.2 & 439.9 & 1.7 \\ 1400 & 464.7 & 467.6 & 439.6 & -\ldots \\ 1600 & 463.1 & 464.4 & 438.8 & 1.7 \\ 1800 & 459.9 & 464.4 & 438.8 & -\ldots \\ & 2000 & 458.3 & 462.7 & 438.8 & 1.7 \\ & 2200 & 456.7 & 459.5 & 438.5 & -- \\ \text { Feb. } 14 & 455.1 & 457.9 & 438.3 & 1.6 \\ & 2400 & 453.5 & 456.3 & 438.3 & -- \\ & 0200 & 450.4 & 454.6 & 438.0 & 1.6 \\ & 0400 & 448.8 & 453.0 & 437.7 & --- \\ & 0600 & 447.2 & 449.8 & 437.5 & 1.6\end{array}$

Re-ran instruments to $5160 \mathrm{ft}$ GL. On bottom at 1045, Feb. 14.

\begin{tabular}{|c|c|c|c|c|c|}
\hline & 1200 & 447.2 & 443.3 & 439.6 & 1.6 \\
\hline & 1400 & 445.6 & 443.3 & 439.9 & --- \\
\hline & 1600 & 444.0 & 441.7 & 439.6 & 1.5 \\
\hline & 1800 & Clock failed & 440.1 & 439.6 & $\cdots$ \\
\hline & 2000 & -- & 438.5 & 439.3 & 1.5 \\
\hline & 2200 & --- & 436.9 & 439.1 & --- \\
\hline & 2400 & --- & 436.9 & 438.8 & 1. 5 \\
\hline \multirow[t]{6}{*}{ Feb. 15} & 0200 & $-\ldots$ & 435.2 & 438.5 & -- \\
\hline & 0400 & -- & 432.0 & 438.5 & 1.5 \\
\hline & 0600 & --- & 430.4 & 438.3 & -- \\
\hline & 0800 & -- & 430.4 & 438.0 & 1.4 \\
\hline & 0820 & --- & 430.4 & -- & -- \\
\hline & 0820 & --- & 436.9 & $\cdots$ & 0.0 \\
\hline
\end{tabular}

Well shut in 0820 for long-term buildup. 
$\bullet$

$-108-$ 


\section{APPENDIX D-4}

BOT TOM HOLE PRESSURE AND TEMPERATURE DATA SECOND PRESSURE BUILD-UP PERIOD

February 15, 1974 to June 24, 1975

(Temperature data, February 15 to March 11, 1974, only)

1974

Date

Feb. 15

Feb. 16
Feb. 17

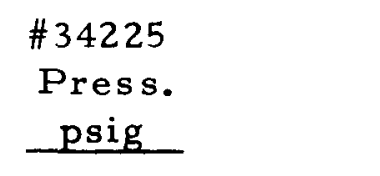

\#33510

Temp.

${ }^{\circ} \mathbf{F}$

$\begin{array}{ll}436.9 & -- \\ 443.3 & 356.6 \\ 446.6 & 340.7 \\ 449.8 & 329.6 \\ 451.4 & 321.6 \\ 454.7 & 315.6 \\ 456.3 & 309.5 \\ 459.5 & 305.6 \\ 461.1 & 302.2 \\ 462.7 & 298.5 \\ 464.4 & 295.5 \\ 467.6 & 293.2\end{array}$

Temperature element range, $180-400^{\circ} \mathrm{F}$. Instruments on bottom, $5160 \mathrm{ft} \mathrm{GL}$ at 1110 , Feb. 15. Reran instruments to $5160^{\prime} \mathrm{GL}$. On bottom at 1245, Feb. 16.

\begin{tabular}{|c|c|c|c|c|}
\hline \multirow[t]{6}{*}{ Feb. 16} & 1400 & 464.7 & 475.7 & 289.2 \\
\hline & 1600 & 467.9 & 477.3 & 287.6 \\
\hline & 1800 & 471.1 & 478.9 & 285.9 \\
\hline & 2000 & 471.1 & 480.5 & 283.9 \\
\hline & 2200 & 474.3 & 483.8 & 282.3 \\
\hline & 2400 & 475.9 & 485.4 & 280.7 \\
\hline \multirow[t]{6}{*}{ Feb. 17} & 0200 & 477.5 & 487.0 & 279.2 \\
\hline & 0400 & 479.1 & 488.6 & 277.9 \\
\hline & 0600 & 482.3 & 490.3 & 276.5 \\
\hline & 0800 & 483.9 & 491.9 & 275.4 \\
\hline & 1000 & 485.5 & 493.5 & 274.2 \\
\hline & 1200 & 487.1 & 493.5 & 273.0 \\
\hline
\end{tabular}

Reran instruments to $5160 \mathrm{ft} \mathrm{GL.} \mathrm{On} \mathrm{bottom} \mathrm{at} \mathrm{1330,} \mathrm{Feb.} 17$. \#33508 has 24-hour clock, others 72-hour clock. 


\section{4 \\ Date}

Feb. 17

Feb. 18

Feb. 19

$\begin{array}{ll}\text { Time } & \begin{array}{c}\# 33508 \\ \text { Press. } \\ \text { psig }\end{array} \\ 1600 & 496.7 \\ 2000 & 498.3 \\ 2400 & 503.1 \\ 0400 & 504.7 \\ 0800 & 506.2 \\ 1200 & 507.8 \\ 1600 & --- \\ 2000 & --- \\ 2400 & --- \\ 0400 & --- \\ 0800 & ---\end{array}$

\begin{tabular}{c}
$\begin{array}{c}\text { \#35 10 } \\
\text { Temp. } \\
{ }^{\circ} \text { F }\end{array}$ \\
\hline \\
272.3 \\
270.1 \\
268.0 \\
266.1 \\
264.5 \\
263.0 \\
261.4 \\
260.0 \\
258.8 \\
257.5 \\
256.1
\end{tabular}

\#33510

Press.

psig

493.5

496.7

500.0

501.6

504.8

508.1

509.7

512.9

516.1

517.8

519.4

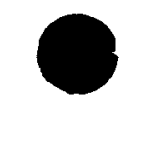

Reran instruments, all with 72 -hour clocks, to $5160 \mathrm{ft} \mathrm{GL}$. On bottom at 1115 , Feb. 19 .

$\begin{array}{ccccc}\text { Feb. } 19 & 1200 & 519.0 & 522.6 & -. \\ & 1600 & 520.6 & 524.2 & 254.1 \\ & 2000 & 523.8 & 527.6 & 252.9 \\ \text { Feb. } 20 & 2400 & 527.0 & 530.7 & 252.0 \\ & 0400 & 528.6 & 532.3 & 251.0 \\ & 0800 & 530.2 & 533.9 & 250.3 \\ & 1200 & 531.8 & 535.6 & 249.7 \\ & 1600 & 535.0 & 538.8 & 248.8 \\ & 2000 & 536.6 & 540.4 & 248.2 \\ \text { Feb. } 21 & 2400 & 538.2 & 542.0 & 247.4 \\ & 0400 & 539.8 & 543.6 & 246.9 \\ & 0800 & 541.4 & 545.3 & 246.3 \\ & 1200 & 543.0 & 546.9 & 245.7 \\ & 1600 & 546.2 & 548.5 & 245.2 \\ & 2000 & 547.8 & 550.1 & 244.6 \\ \text { Feb. } 22 & 2400 & 549.4 & 551.7 & 244.2 \\ & 0400 & -.-1243 & 242.5\end{array}$

Reran instruments to $5160 \mathrm{ft} \mathrm{GL.} \mathrm{On} \mathrm{bottom} \mathrm{at} \mathrm{1330,} \mathrm{Feb.} 22$

$\begin{array}{ccc}\text { Feb. 22 } & 1600 & 555.6 \\ & 2000 & 557.2 \\ & 2400 & 560.4 \\ \text { Feb. } 23 & 0400 & 561.9 \\ & 0800 & 563.6\end{array}$


1974

Date

Feb. 23

Feb. 24

Feb. 25
\#33508

Press.

$\underline{\text { Time }}$

1200

1600

2000

2400

0400

0800

1200

1600

2000

2400

0400

0800
\#34225

Press.

psig

575.6

577.2

578.9

580.5

582.1

583.7

583.7

585.4

587.0

588.6

590.2

591.9
\#33510

Temp.

${ }^{\circ} \mathrm{F}$

234.4

234.2

233.7

233.4

232.9

232.5

232.2

232.0

231.7

231.2

231.0

230.7

Reran instruments to $5160 \mathrm{ft} \mathrm{GL}$. On bottom at 1215, Feb. 25.

Feb. 25

1600

2000

2400

Feb. 26

0400

0800

1200

1600

2000

2400

Feb. 27

0400

0800

1200

592.2
595.4
597.0
598.6
600.2
601.8
603.4
605.0
606.6
608.1
609.7
611.3

596.7

600.0

601.6

604.9

604.9

606.5

609.8

611.4

613.0

613.0

614.6

614.6
231.2

230.7

230.5

230.2

230.0

229.7

229.4

229.4

229.1

229. 1

228.9

228.6

Reran instruments to $5160 \mathrm{ft} \mathrm{GL}$. On bottom at 1300, Feb. 27. Changed clock on \#33508.

$\begin{array}{lll}\text { Feb. } 27 & 1600 & \text { Misrun } \\ & 2000 & --- \\ \text { Feb. } 28 & 2400 & -- \\ & 0400 & -- \\ & 0800 & -- \\ & 1200 & -- \\ & 1600 & -- \\ \text { Mar. } 1 & 2000 & -- \\ & 2400 & -- \\ & 0400 & -- \\ & 0800 & --\end{array}$

614.6

617.9

619.5

621.1

622.8

624.4

626.0

627.6

629.3

629.3

630.9
226.9

226.9

227.2

227.5

227.5

227.5

227.5

227.5

227.2

226.9

226.9 
Reran instruments to $5160 \mathrm{ft}$ GL. On bottom at 1230, Mar. 1 . Replaced temperature element \#33510 with element \#34226 $150-400^{\circ} \mathrm{F}$. Replaced bad clock in \#33508.

1974

Date

Mar. 1

Mar. 2

$\begin{array}{cc} & 0800 \\ & 1200 \\ & 1600 \\ & 2000 \\ \text { Mar. 3 } & 2400 \\ & 0400 \\ & 0800 \\ & 1200 \\ & 1600 \\ \text { Mar. 4 } & 2000 \\ & 2400 \\ & 0400 \\ & 0800\end{array}$

\begin{tabular}{l} 
\#33508 \\
Press. \\
psig \\
\hline \\
632.0 \\
635.2 \\
636.8 \\
638.4 \\
638.4 \\
640.0 \\
641.6 \\
644.8 \\
646.4 \\
646.4 \\
647.9 \\
649.5 \\
651.1 \\
652.7 \\
654.3 \\
655.9 \\
655.9
\end{tabular}

$\begin{array}{cc}\begin{array}{c}\text { \#34225 } \\ \text { Press. } \\ \text { psig }\end{array} & \begin{array}{c}\text { \#34226 } \\ \text { Temp. } \\ \text { oF }\end{array} \\ 634.1 & 216.0 \\ 635.8 & 217.3 \\ 637.4 & 217.8 \\ 639.0 & 218.3 \\ 640.6 & 218.5 \\ 642.3 & 218.8 \\ 643.9 & 219.3 \\ 643.9 & 219.5 \\ 645.5 & 219.5 \\ 647.1 & 219.8 \\ 647.1 & 219.8 \\ 648.8 & 220.0 \\ 648.8 & 220.0 \\ 650.4 & 220.3 \\ 652.0 & --- \\ 652.0 & --- \\ 655.3 & --\end{array}$

Reran instruments to $5160 \mathrm{ft} \mathrm{GL.} \mathrm{On} \mathrm{bottom} \mathrm{at} \mathrm{1400,} \mathrm{Mar.} 4$.

$\begin{array}{cl}\text { Mar. 4 } & 1600 \\ & 2000 \\ \text { Mar. 5 } & 2400 \\ & 0400 \\ & 0800 \\ & 1200 \\ & 1600 \\ & 2000 \\ \text { Mar. 6 } & 2400 \\ & 0400 \\ & 0800 \\ & 1200 \\ & 1600 \\ & 2000 \\ & 2400\end{array}$

655.3
656.9
660.2
661.8
663.4
665.0
666.7
668.3
669.9
669.9
671.5
671.5
673.2
676.4
676.4

214.5 214.5

215.3

216.3

216.8

217.0

217.0

217.5

217.8

218.0

217.8

218.0

218.0

218.3

218.5 
1974

Date

Mar. 7
\#33508

Press.

Time

0400

0800

1200

psig

675.0

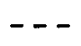

\#34225

Press.

psig

678.0

678.0

679.7
\#34226

Temp.

${ }^{\circ} F$

218.8

218.8

218.8

Reran instruments to $5160 \mathrm{ft} \mathrm{GL}$. On bottom at 1315, Mar. 7.

$\begin{array}{cl}\text { Mar. } 7 & 1600 \\ & 2000 \\ \text { Mar. 8 } & 2400 \\ & 0400 \\ & 0800 \\ & 1200 \\ & 1600 \\ & 2000 \\ \text { Mar. 9 } & 2400 \\ & 0400 \\ & 0800 \\ & 1200 \\ & 1600 \\ & 2000 \\ \text { Mar. 10 } & 2400 \\ & 0400 \\ & 0800 \\ & 1200\end{array}$

679.8
681.4
683.0
684.6
684.6
686.2
687.7
689.3
690.9
690.9
690.9
692.5
694.1
695.7
697.3
697.3
--
--1

682.9

684.5

686.2

687.8

689.4

689.4

691.1

692.7

692.7

694.3

694.3

695.5

695.5

697.6

697.6

699.2

699.2

700.8
209.2

211.0

211.9

212.7

213.3

213.3

214.2

214.5

214.5

215.0

215.0

215.0

215.5

215.8

215.8

216.0

216.0

216.0

Reran instruments with 24-hour clocks to $5160 \mathrm{ft} \mathrm{GL}$. On bottom at 1515, Mar. 10.

$\begin{array}{ll}\text { Mar. } 10 & 1600 \\ & 2000 \\ & 2400 \\ \text { Mar. } 11 & 0400 \\ & 0800 \\ & 1200\end{array}$

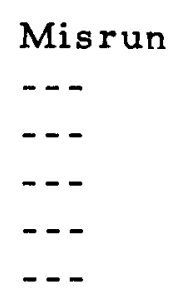

699.2

704.1

203. 4

206.3

207.5

208. 1

209. 0

209.5

Pulled down lubricator and stripped 092 stainless wire from wire line unit in preparation for installation of Sperry Sun equipment on Mar. 12. 


\begin{tabular}{|c|c|c|c|c|c|}
\hline $\begin{array}{l}1974 \\
\text { Date }\end{array}$ & Time & $\begin{array}{l}\text { BHP } \\
\text { psia }\end{array}$ & $\begin{array}{l}1974 \\
\text { Date }\end{array}$ & Time & $\begin{array}{l}\text { BHP } \\
\text { psia }\end{array}$ \\
\hline \multirow[t]{2}{*}{ Mar. 13} & 1435 & 713.6 & Mar. 23 & 0800 & 768.7 \\
\hline & 2400 & 718.7 & & 1600 & 771.5 \\
\hline \multirow{3}{*}{ Mar. 14} & 0800 & 720.6 & & 2400 & 771.5 \\
\hline & 1600 & 723.9 & Mar. 24 & 0800 & 772.9 \\
\hline & & & & 1600 & 775.5 \\
\hline \multicolumn{4}{|c|}{ Sperry Sun downhole chamber is located } & 2400 & 775.9 \\
\hline \multicolumn{4}{|c|}{ at $5160 \mathrm{ft} \mathrm{GL.} \mathrm{Gas} \mathrm{Column} \mathrm{inside} \mathrm{of} \mathrm{tube}$} & 0800 & 777.9 \\
\hline \multicolumn{4}{|c|}{ is helium. In calculating bottom-hole } & 1600 & 781.3 \\
\hline \multicolumn{4}{|c|}{ psia, surface psig was corrected to psia } & 2400 & 780.7 \\
\hline \multicolumn{4}{|c|}{ by using average barometric pressure of } & 0800 & 782.5 \\
\hline \multicolumn{4}{|c|}{11.5 psia prior to applying correction } & 1600 & 785.5 \\
\hline \multirow{3}{*}{\multicolumn{3}{|c|}{$\begin{array}{l}\text { factor of } 1.02265 \text { for mass per unit area } \\
\text { of gas column. }\end{array}$}} & & 2400 & 785.7 \\
\hline & & & Mar. 27 & 0800 & 786.9 \\
\hline & & & & 1600 & 790.7 \\
\hline \multirow{2}{*}{\multicolumn{3}{|c|}{$\begin{array}{l}\text { Data from } 2400 \text {, Mar. } 14 \text { to } 0800 \text {, Mar. } \\
18 \text { omitted because of a small leak which }\end{array}$}} & & 2400 & 789.8 \\
\hline & & & Mar. 28 & 0800 & 791.7 \\
\hline
\end{tabular}

was found and repaired on Mar. 18 as noted below.

Mar. 18. Checked Sperry Sun equipment and found pressure readout at 681 surface psig, a drop from data on Mar. 15. Checked all fittings with soap solution and found small leak on 3-way valve. Repaired leak and repurged system with helium.

$\begin{array}{cll}\text { Mar. 21 } & 1600 & 760.9 \\ \text { Mar. 22 } & 2400 & 760.6 \\ & 0800 & 762.1 \\ & 1600 & 764.7 \\ & 2400 & 767.0\end{array}$

743. 4 746. 0 747.6 750.7 750.5 752.3 755.6 755.8 757.1

Reset time mechanism on Sperry Sun equipment at 1300, Mar. 21.
Reset pressure and time mechanism on Sperry Sun equipment at 1600, Mar. 28.

$\begin{array}{cll}\text { Mar. 28 } & 1600 & 794.3 \\ \text { Mar. 29 } & 2400 & 794.6 \\ & 0800 & 796.4 \\ & 1600 & 799.8 \\ \text { Mar. 30 } & 2400 & 799.8 \\ & 0800 & 801.0 \\ & 1600 & 803.8 \\ \text { Mar. 31 } & 2400 & 804.6 \\ & 0630 & 805.1 \\ & 1600 & 807.7 \\ \text { April 1 } & 2400 & 808.4 \\ & 0800 & 809.8 \\ \text { April 2 } & 1600 & 812.4 \\ & 2400 & 813.1 \\ & 0800 & 814.7 \\ \text { April 3 } & 1600 & 816.8 \\ & 2400 & 817.7 \\ & 0800 & 819.2 \\ \text { April 4 } & 1600 & 821.4 \\ & 2400 & 322.1 \\ & 0800 & 823.4\end{array}$

Reset pressure and time mechanism on Sperry Sun equipment at 1500, April 4. Recorder malfunction at 0800 , Mar. 31 


\begin{tabular}{|c|c|c|c|c|c|}
\hline $\begin{array}{l}1974 \\
\text { Date }\end{array}$ & Time & $\begin{array}{l}\text { BHP } \\
\text { psia }\end{array}$ & $\begin{array}{l}1974 \\
\text { Date }\end{array}$ & \multicolumn{2}{|r|}{ BHP } \\
\hline \multirow[t]{2}{*}{ April 4} & 1600 & 826.5 & April 18 & 0800 & 879.9 \\
\hline & 2400 & 826.9 & & & \\
\hline \multirow[t]{3}{*}{ April 5} & 0800 & 828.9 & \multirow{3}{*}{\multicolumn{3}{|c|}{$\begin{array}{l}\text { Reset pressure and time mechanism } \\
\text { on Sperry Sun equipment at } 1500 \text {, } \\
\text { April } 18 .\end{array}$}} \\
\hline & 1600 & 831.7 & & & \\
\hline & 2400 & 832.2 & & & \\
\hline \multirow[t]{3}{*}{ April 6} & 0800 & 833.7 & & & \\
\hline & 1600 & 837.6 & \multirow[t]{2}{*}{ April 18} & 1600 & 889.5 \\
\hline & 2400 & 838.5 & & 2400 & 885.3 \\
\hline \multirow[t]{3}{*}{ April 7} & 0800 & 840.0 & \multirow[t]{3}{*}{ April 19} & 0800 & 885.1 \\
\hline & 1600 & 842.4 & & 1600 & 889.9 \\
\hline & 2400 & 842.4 & & 2400 & 885.9 \\
\hline \multirow[t]{3}{*}{ April 8} & 0800 & 844. 1 & \multirow[t]{3}{*}{ April 20} & 0800 & 884.0 \\
\hline & 1600 & 847.8 & & 1600 & 891.0 \\
\hline & 2400 & 850.0 & & 2400 & 890.0 \\
\hline \multirow[t]{3}{*}{ April 9} & 0800 & 851.3 & \multirow[t]{3}{*}{ April 21} & 0800 & 890.5 \\
\hline & 1600 & 854.6 & & 1600 & 898.1 \\
\hline & 2400 & 854.2 & & 2400 & 893.6 \\
\hline \multirow[t]{3}{*}{ April 10} & 0800 & 855.8 & \multirow[t]{3}{*}{ April 22} & 0800 & 892.1 \\
\hline & 1600 & 857.1 & & 1600 & 904.4 \\
\hline & 2400 & 858.0 & & 2400 & 898.4 \\
\hline \multirow[t]{2}{*}{ April 11} & 0800 & 859.3 & \multirow[t]{2}{*}{ April 23} & 0800 & 896.9 \\
\hline & & & & 1600 & 907.3 \\
\hline \multirow{4}{*}{\multicolumn{3}{|c|}{$\begin{array}{l}\text { Reset pressure and time mechanism } \\
\text { on Sperry Sun equipment at } 1000 \text {, } \\
\text { April } 11 .\end{array}$}} & \multirow{4}{*}{ April 24} & 2400 & 902.7 \\
\hline & & & & 0800 & 903.5 \\
\hline & & & & 1600 & 909.9 \\
\hline & & & & 2400 & 908.1 \\
\hline \multirow[t]{2}{*}{ April 11} & 1600 & 860.8 & April 25 & 0800 & 908.2 \\
\hline & 2400 & 862.0 & & 1600 & 914.2 \\
\hline April 12 & 0800 & 863.0 & & & \\
\hline & 1600 & 865.0 & Reset pre & and tir & chanism \\
\hline & 2400 & 865.5 & on Sper r & quipme & 830 \\
\hline April 13 & 0800 & 866.8 & April 25. & & \\
\hline & 1600 & 869.0 & & & \\
\hline & 2400 & 869.4 & April 25 & 2400 & 911.1 \\
\hline April 14 & 0800 & 870.6 & April 26 & 0800 & 908.6 \\
\hline & 1600 & 873.3 & & 1600 & 914.8 \\
\hline & 2400 & 873.0 & & 2400 & 912.2 \\
\hline April 15 & 0800 & 874.7 & April 27 & 0800 & 910.4 \\
\hline & 1600 & 879.4 & & 1600 & 917.9 \\
\hline & 2400 & 876.5 & & 2400 & 913.7 \\
\hline April 16 & 0800 & 878.4 & April 28 & 0800 & 911.7 \\
\hline & 1600 & 882.5 & & 1600 & 923.5 \\
\hline & 2400 & 878.5 & & 2400 & 918.8 \\
\hline April 17 & 0800 & 879.4 & April 29 & 0800 & 915.6 \\
\hline & 1600 & 886.0 & & 1600 & 925.7 \\
\hline & 2400 & 881.3 & & 2400 & 919.4 \\
\hline
\end{tabular}




\begin{tabular}{|c|c|c|c|c|c|}
\hline $\begin{array}{l}1974 \\
\text { Date }\end{array}$ & Time & $\begin{array}{l}\text { BHP } \\
\text { psia }\end{array}$ & $\begin{array}{l}1974 \\
\text { Date }\end{array}$ & Time & $\begin{array}{l}\text { BHP } \\
\text { psia }\end{array}$ \\
\hline \multirow{3}{*}{ April 30} & 0800 & 918.2 & May 15 & 0800 & 970.6 \\
\hline & 1600 & 932.1 & & 1600 & 978.0 \\
\hline & 2400 & 925.7 & & 2400 & 974.6 \\
\hline \multirow[t]{3}{*}{ May 1} & 0800 & 925.9 & May 16 & 0800 & 970.7 \\
\hline & 1600 & 334.5 & & 1400 & 979.9 \\
\hline & 2400 & 931.0 & & 1600 & 1002.8 \\
\hline \multirow[t]{3}{*}{ May 2} & 0800 & 934.2 & & & \\
\hline & 1600 & 935.5 & \multicolumn{3}{|c|}{ At 1400 , May 16 , closed valve in } \\
\hline & 2400 & 931.2 & \multicolumn{3}{|c|}{ instrument tubing at reel and dis- } \\
\hline \multirow[t]{3}{*}{ May 3} & 0800 & 929.5 & \multirow{3}{*}{\multicolumn{3}{|c|}{$\begin{array}{l}\text { connected Surface Recorder S.N. } \\
\text { PMS- } 4 \text {. Instrument zeroed in } \\
9983.4 \text { psi or minus } 16.6 \text { psi. }\end{array}$}} \\
\hline & 1600 & 940.0 & & & \\
\hline & 2400 & 936.8 & & & \\
\hline \multirow[t]{3}{*}{ May 4} & 0800 & 933.6 & \multicolumn{3}{|c|}{ Installed Surface Recorder S.N. } \\
\hline & 1600 & 944.1 & \multirow{2}{*}{\multicolumn{3}{|c|}{$\begin{array}{l}\text { PMS-3. Purged twice with helium. } \\
\text { Pressure read-out after purges indi- }\end{array}$}} \\
\hline & 2400 & 939.2 & & & \\
\hline \multirow[t]{3}{*}{ May 5} & 0800 & 935.8 & \multicolumn{3}{|c|}{ cated complete system had been } \\
\hline & 1600 & 946.7 & \multirow{2}{*}{\multicolumn{3}{|c|}{$\begin{array}{l}\text { purged. Reset at } 1600 \text {, May } 16 . \\
\text { All surface connections were tested }\end{array}$}} \\
\hline & 2400 & 943.7 & & & \\
\hline \multirow[t]{3}{*}{ May 6} & 0800 & 942.3 & \multicolumn{3}{|c|}{ for leaks. } \\
\hline & 1600 & 949.8 & & & \\
\hline & 2400 & 947.6 & \multirow[t]{4}{*}{ May 20} & 1630 & Reset \\
\hline \multirow[t]{3}{*}{ May 7} & 0800 & 945.7 & & 16.35 & Purged \\
\hline & 1600 & 955.5 & & & with 4.5 \\
\hline & 2400 & 951.0 & & & $\mathrm{cu} \mathrm{ft}$ \\
\hline \multirow[t]{3}{*}{ May 8} & 0800 & 949.4 & & & helium \\
\hline & 1600 & 958.5 & & 2400 & 1007.2 \\
\hline & 2400 & 954.4 & \multirow[t]{3}{*}{ May 21} & 0800 & 988.4 \\
\hline \multirow[t]{3}{*}{ May 9} & 0800 & 953.8 & & 1600 & 1012.8 \\
\hline & 1600 & 961.6 & & 2400 & 1009.9 \\
\hline & 2400 & 958.3 & \multirow[t]{3}{*}{ May 22} & 0800 & 1011.2 \\
\hline \multirow[t]{3}{*}{ May 10} & 0800 & 957.5 & & 1600 & 1015.8 \\
\hline & 1600 & 963.2 & & 2400 & 1013.0 \\
\hline & 2400 & 958.6 & \multirow{2}{*}{ May 23} & 0800 & 1014.0 \\
\hline May 11 & 0800 & 955.1 & & & \\
\hline & 1600 & 965.3 & Valves a & hgs wer & eived for \\
\hline & 2400 & 961.2 & adding a & Model & pressure \\
\hline May 12 & 0800 & 958.4 & recorde & Dead W & Pressure \\
\hline & 1600 & 968.4 & Gauge te & ection & he surface \\
\hline & 2400 & 966.8 & system. & & \\
\hline May 13 & 0800 & 964.6 & & & \\
\hline & 1600 & 970.3 & May 23 & 1600 & 1018.1 \\
\hline & 2400 & 966.2 & & 2400 & 1016.8 \\
\hline May 14 & 0800 & 963.2 & May 24 & 0800 & 1016.1 \\
\hline & 1600 & 973.4 & & 1600 & 1020.6 \\
\hline & 2400 & 969.4 & & 2400 & 1020.0 \\
\hline
\end{tabular}




\begin{tabular}{|c|c|c|c|c|c|}
\hline $\begin{array}{l}1974 \\
\text { Date }\end{array}$ & \multicolumn{2}{|r|}{$\begin{array}{l}\text { BHP } \\
\text { psia }\end{array}$} & $\begin{array}{l}1974 \\
\text { Date }\end{array}$ & \multicolumn{2}{|r|}{ BHP } \\
\hline \multirow[t]{3}{*}{ May 25} & 0800 & 1018.4 & June 4 & 0800 & 1053.8 \\
\hline & 1600 & 1023.9 & & 1600 & 1055.5 \\
\hline & 2400 & 1023.4 & & 2400 & 1055.1 \\
\hline \multirow[t]{3}{*}{ May 26} & 0800 & 1020.8 & June 5 & 0800 & 1055.0 \\
\hline & 1600 & 1026.3 & & 1600 & 1056.4 \\
\hline & 2400 & 1026.1 & & 2400 & 1057.0 \\
\hline \multirow[t]{3}{*}{ May 27} & 0800 & 1022.9 & June 6 & 0800 & 1058.0 \\
\hline & 1600 & 1028.4 & & 1600 & 1060.0 \\
\hline & 2400 & $\ldots-$ & & & \\
\hline \multirow[t]{2}{*}{ May 28} & 1600 & 1031.1 & \multirow{2}{*}{\multicolumn{3}{|c|}{$\begin{array}{l}\text { Reset time mechanism on Sperry Sun } \\
\text { equipment at } 1630 \text {, June } 6 \text {. }\end{array}$}} \\
\hline & 2400 & 1027.8 & & & \\
\hline \multirow[t]{2}{*}{ May 29} & 0800 & 1029.7 & & & \\
\hline \multirow{8}{*}{\multicolumn{3}{|c|}{$\begin{array}{l}\text { At } 1300, \text { May } 29 \text {, shut down equipment } \\
\text { for installation of Barton } 202 \mathrm{~A} \text { Pres- } \\
\text { sure Recorder and Dead Weight Test- } \\
\text { er on tailgate of Sperry Sun equipment. } \\
\text { Repurged system with helium, reset } \\
\text { time and pressure. }\end{array}$}} & June 6 & 2400 & 1060.0 \\
\hline & & & June 7 & 0800 & 1060.5 \\
\hline & & & & 1600 & 1062.5 \\
\hline & & & & 2400 & 1062.4 \\
\hline & & & June 8 & 0800 & 1062.2 \\
\hline & & & & 1600 & 1064.1 \\
\hline & & & & 2400 & 1064.4 \\
\hline & & & June 9 & 0800 & 1064.7 \\
\hline \multirow[t]{3}{*}{ May 29} & 1400 & 1039.3 & & 1600 & 1066.9 \\
\hline & 1600 & 1041.5 & & 2400 & 1064.8 \\
\hline & 2400 & 1040.2 & June 10 & 0800 & 1066.7 \\
\hline \multirow[t]{2}{*}{ May 30} & 0800 & 1040.4 & & 1600 & 1069.0 \\
\hline & & & & 2400 & 1066.3 \\
\hline \multicolumn{3}{|c|}{ Checked Dead Weight against Sperry } & June 11 & 0800 & 1068.5 \\
\hline \multirow{4}{*}{\multicolumn{3}{|c|}{$\begin{array}{l}\text { Sun equipment and found } 2 \text { psi differ - } \\
\text { ence. Chart from previous } 24 \text { hour } \\
\text { period showed no appreciable amount } \\
\text { of fluctuation. }\end{array}$}} & & 1600 & 1072.4 \\
\hline & & & & 2400 & 1068.6 \\
\hline & & & June 12 & 0800 & 1070.6 \\
\hline & & & & 1600 & 1074.4 \\
\hline & & & & 2400 & 1071.7 \\
\hline \multirow[t]{2}{*}{ May 30} & 1600 & 1046.4 & June 13 & 0800 & 1070.9 \\
\hline & 2400 & 1041.6 & & & \\
\hline \multirow[t]{3}{*}{ May 31} & 0800 & 1043.8 & \multirow{3}{*}{\multicolumn{3}{|c|}{$\begin{array}{l}\text { Reset time mechanism on equipment } \\
\text { at } 1130 \text {, June } 13 \text {. }\end{array}$}} \\
\hline & 1600 & 1049.2 & & & \\
\hline & 2400 & 1044.7 & & & \\
\hline \multirow[t]{3}{*}{ June 1} & 0800 & 1046.3 & June 13 & 1600 & 1076.9 \\
\hline & 1600 & 1051.0 & & 2400 & 1072.2 \\
\hline & 2400 & 1046.5 & June 14 & 0800 & 1076.5 \\
\hline \multirow[t]{3}{*}{ June 2} & 0800 & 1049.1 & & 1600 & 1079.3 \\
\hline & 1600 & 1054.1 & & 2400 & 1074.7 \\
\hline & 2400 & 1050.1 & June 15 & 0800 & 1077.1 \\
\hline \multirow[t]{3}{*}{ June 3} & 0800 & 1051.1 & & 1600 & 1081.0 \\
\hline & 1600 & 1054.1 & & 2400 & 1078.4 \\
\hline & 2400 & 1052.3 & & & \\
\hline
\end{tabular}




$\begin{array}{ccc}\begin{array}{c}1974 \\ \text { Date }\end{array} & \text { Time } & \begin{array}{c}\text { BHP } \\ \text { psia }\end{array} \\ \text { June } 16 & 0800 & 1078.4 \\ & 1600 & 1082.7 \\ \text { June } 17 & 2400 & 1078.4 \\ & 0800 & 1080.7 \\ \text { June } 18 & 1600 & 1084.6 \\ & 2400 & 1081.1 \\ \text { June } 19 & 0800 & 1083.3 \\ & 1600 & 1086.9 \\ & 2400 & 1082.5 \\ \text { June } 20 & 0800 & 1073.2 \\ & 1600 & 1073.1 \\ & 2400 & 1054.8 \\ & 0800 & 1053.9\end{array}$

Replaced Sperry Sun equipment with new surface readout and print out machine supplied as replacement by Sperry Sun.

The data from 2400, June 18 , to 0800 , June 20 , are questionable since they drop off quite rapidly. The connections on all of the equipment were checked for leaks but none were found.

$\begin{array}{ccc}\text { June 20 } & 1600 & 1104.0 \\ \text { June 21 } & 2400 & 1098.8 \\ & 0800 & 1099.3 \\ & 1600 & 1105.8 \\ \text { June 22 } & 2400 & 1101.5 \\ & 0800 & 1099.9 \\ \text { June 23 } & 1600 & 1106.5 \\ & 2400 & 1103.4 \\ \text { June 24 } & 0800 & 1099.8 \\ & 1600 & 1108.7 \\ & 2400 & 1105.5 \\ & 0800 & 1102.1\end{array}$

At 1100, June 24, the Perma Gauge was moved from its old location in the office trailer to a rack mounted position in the lab trailer. A considerable difference was noticed in the amount of fluctuation caused by change 


\begin{tabular}{ccc}
1974 & Time & $\begin{array}{c}\text { BHP } \\
\text { psia }\end{array}$ \\
\hline July 4 & 1600 & 1128.7 \\
& 2400 & 1128.7 \\
July 5 & 0800 & 1134.2 \\
& 1600 & 1135.0 \\
July 6 & 2400 & 1134.9 \\
& 0800 & 1134.9 \\
July 7 & 1600 & 1136.6 \\
& 2400 & 1137.6 \\
& 0800 & 1137.6 \\
July 8 & 1600 & 1137.6 \\
& 2400 & 1137.6 \\
& 0800 & 1137.6 \\
July 9 & 1600 & 1137.6 \\
& 2400 & 1137.6 \\
& 0800 & 1137.6 \\
July 10 & 1600 & 1142.9 \\
& 2400 & 1143.7 \\
& 0800 & 1143.7 \\
July 11 & 1600 & 1144.9 \\
& 2400 & 1146.0 \\
& 0800 & 1145.9
\end{tabular}

Date Time psia

Checked Sperry Sun equipment with Dead Weight and checked out the same as read out. Purged system with helium. Reset time mechanism on Sperry Sun equipment at 1100, July 11 .

$\begin{array}{cll}\text { July } 11 & 1600 & 1148.1 \\ \text { July } 12 & 2400 & 1149.5 \\ & 0800 & 1148.9 \\ & 1600 & 1149.8 \\ \text { July } 13 & 2400 & 1149.8 \\ & 0800 & 1149.8 \\ \text { July } 14 & 1600 & 1149.8 \\ & 2400 & 1149.8 \\ \text { July } 15 & 0800 & 1149.8 \\ & 1600 & 1149.8 \\ & 2400 & 1149.8 \\ \text { July } 16 & 0800 & 1149.8 \\ & 1600 & 1149.8 \\ & 2400 & 1149.8 \\ & 0800 & 1149.8 \\ & 1600 & 1150.9\end{array}$




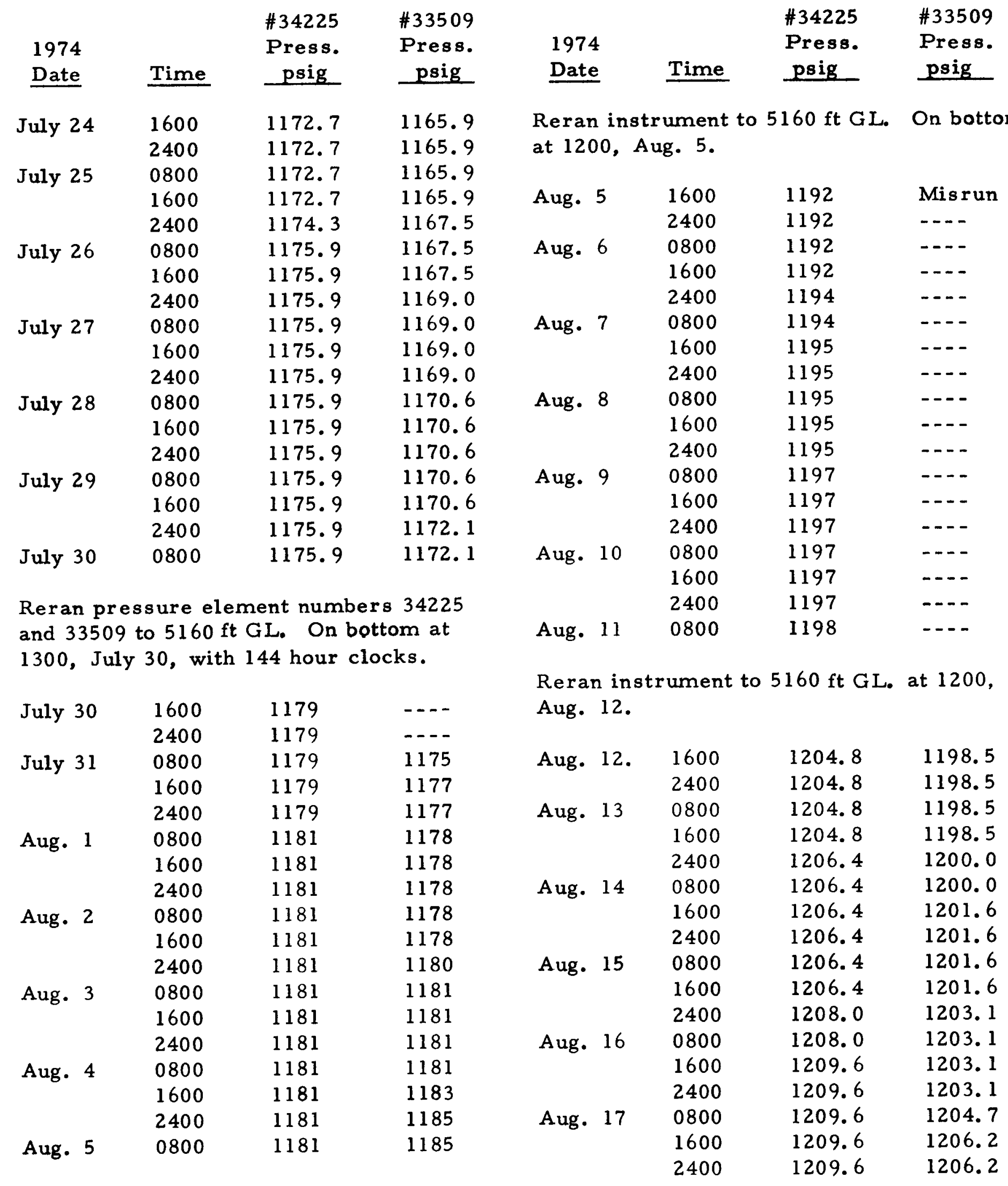




\begin{tabular}{|c|c|c|c|}
\hline $\begin{array}{l}1974 \\
\text { Date }\end{array}$ & Time & $\begin{array}{c}\# 34225 \\
\text { Press. } \\
\text { psig }\end{array}$ & $\begin{array}{c}\# 33509 \\
\text { Press. } \\
\text { psig }\end{array}$ \\
\hline Aug. 18 & 0800 & 1209.6 & 1206.2 \\
\hline \multicolumn{4}{|c|}{$\begin{array}{l}\text { Reran instrument to } 5160 \mathrm{ft} \mathrm{GL.} \mathrm{On} \mathrm{bottor} \\
\text { at } 1300 \text {, Aug. } 19 .\end{array}$} \\
\hline \multirow[t]{2}{*}{ Aug. 19} & 1600 & 1213 & 1209 \\
\hline & 2400 & 1213 & 1209 \\
\hline \multirow[t]{3}{*}{ Aug. 20} & 0800 & 1213 & 1209 \\
\hline & 1600 & 1213 & 1211 \\
\hline & 2400 & 1213 & 1211 \\
\hline \multirow{3}{*}{ Aug. 21} & 0800 & 1213 & 1212 \\
\hline & 1600 & 1213 & 1212 \\
\hline & 2400 & 1213 & 1212 \\
\hline \multirow[t]{3}{*}{ Aug. 22} & 0800 & 1213 & 1212 \\
\hline & 1600 & 1214 & 1214 \\
\hline & 2400 & 1216 & 1216 \\
\hline Aug. 23 & 0800 & 1216 & 1216 \\
\hline
\end{tabular}

At 1300, Aug. 23, instruments were pulled to surface because of a lubricator packing failure. Instruments were back at a depth of $5050 \mathrm{ft} \mathrm{GL}$ at 1500, Aug. 23. The instruments were set at this depth because of a bad kink in wireline caused by bad packing on the pullout.

$\begin{array}{llll}\text { Aug. 23 } & 1600 & 1222 & 1211 \\ & 2400 & 1222 & 1211 \\ \text { Aug. 24 } & 0800 & 1224 & 1211 \\ & 1600 & 1224 & 1212 \\ & 2400 & 1224 & 1212 \\ \text { Aug. 25 } & 0800 & 1226 & 1214 \\ & 1600 & 1226 & 1214 \\ \text { Aug. 26 } & 2400 & 1226 & 1214 \\ & 0800 & 1226 & 1214 \\ \text { Aug. 27 } & 1600 & 1226 & 1214 \\ & 2400 & 1227 & 1216 \\ & 0800 & 1227 & 1216 \\ \text { Aug. 28 } & 1600 & 1227 & 1217 \\ & 2400 & 1227 & 1217 \\ & 0800 & 1227 & 1217 \\ & 1600 & 1227 & 1219 \\ & 2400 & 1230 & 1219\end{array}$

\#33509

Press. Press. psig psig

1230

At 0900 , Aug. 29, pulled instrument from hole and changed 0.092-in. stainless steel wireline. On bottom, $5160 \mathrm{ft} \mathrm{GL}$ at 1800 . Aug. 29.

The above data was obtained from instrument at 5050 . ft GL as noted above.

$\begin{array}{llll}\text { Aug. 29 } & 2400 & 1238 & 1228 \\ \text { Aug. 30 } & 0800 & 1238 & 1228 \\ & 1600 & 1238 & 1228 \\ & 2400 & 1240 & 1230 \\ \text { Aug. 31 } & 0800 & 1240 & 1230 \\ & 1600 & 1240 & 1230 \\ \text { Sept. 1 } & 2400 & 1242 & 1230 \\ & 0800 & 1242 & 1230 \\ & 1600 & 1242 & 1230 \\ \text { Sept. 2 } & 2400 & 1242 & 1230 \\ & 0800 & 1242 & 1231 \\ & 1600 & 1243 & 1231 \\ \text { Sept. 3 } & 2400 & 1243 & 1231 \\ & 0800 & 1243 & 1231 \\ & 1600 & 1243 & 1231 \\ \text { Sept. 4 } & 2400 & 1243 & 1233 \\ & 0800 & 1243 & 1233\end{array}$

Reran instrument to $5160 \mathrm{ft} \mathrm{GL}$. On bottom at 1600 , Sept. 4.

\begin{tabular}{|c|c|c|c|}
\hline Sept. 4 & 2400 & 1238 & 1234 \\
\hline \multirow[t]{3}{*}{ Sept. 5} & 0800 & 1238 & 1234 \\
\hline & 1600 & 1238 & 1234 \\
\hline & 2400 & 1240 & 1234 \\
\hline \multirow{3}{*}{ Sept. 6} & 0800 & 1240 & 1234 \\
\hline & 1600 & 1240 & 1236 \\
\hline & 2400 & 1240 & 1236 \\
\hline \multirow[t]{3}{*}{ Sept. 7} & 0800 & 1240 & 1236 \\
\hline & 1600 & 1240 & 1236 \\
\hline & 2400 & 1242 & 1236 \\
\hline \multirow[t]{3}{*}{ Sept. 8} & 0800 & 1242 & 1237 \\
\hline & 1600 & 1242 & 1237 \\
\hline & 2400 & 1242 & 1237 \\
\hline
\end{tabular}




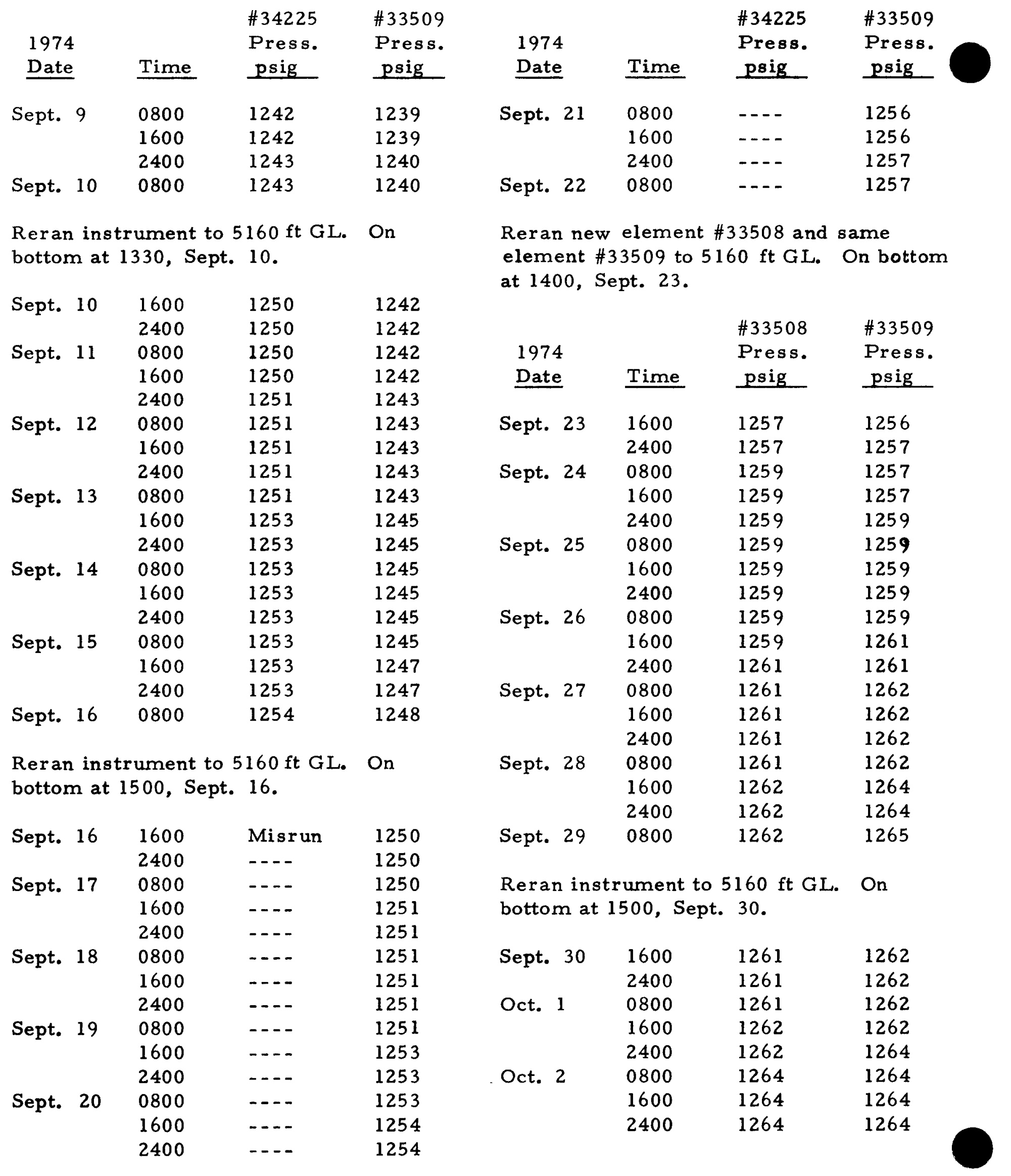




\begin{tabular}{|c|c|c|c|c|c|c|c|}
\hline $\begin{array}{l}1974 \\
\text { Date }\end{array}$ & Time & $\begin{array}{l}\# 33508 \\
\text { Press. } \\
\text { psig }\end{array}$ & $\begin{array}{l}\# 33509 \\
\text { Press. } \\
\text { psig }\end{array}$ & $\begin{array}{l}1974 \\
\text { Date }\end{array}$ & Time & $\begin{array}{l}\# 33508 \\
\text { Press. } \\
\text { psig }\end{array}$ & $\begin{array}{c}\# 33509 \\
\text { Press. } \\
\text { psig } \\
\end{array}$ \\
\hline \multirow[t]{3}{*}{ Oct. 3} & 0800 & 1264 & 1264 & Oct. 17 & 0800 & 1284 & 1285 \\
\hline & 1600 & 1265 & 1264 & & 1600 & 1284 & 1285 \\
\hline & 2400 & 1265 & 1265 & & 2400 & 1285 & 1287 \\
\hline \multirow[t]{3}{*}{ Oct. 4} & 0800 & 1265 & 1265 & Oct. 18 & 0800 & 1285 & 1287 \\
\hline & 1600 & 1265 & 1267 & & 1600 & 1285 & 1287 \\
\hline & 2400 & 1267 & 1267 & & 2400 & 1285 & 1287 \\
\hline \multirow[t]{3}{*}{ Oct. 5} & 0800 & 1267 & 1267 & Oct. 19 & 0800 & 1285 & 1287 \\
\hline & 1600 & 1267 & 1268 & & 1600 & 1287 & 1287 \\
\hline & 2400 & 1268 & 1268 & & 2400 & 1287 & 1288 \\
\hline \multirow[t]{2}{*}{ Oct. 6} & 0800 & 1268 & 1268 & Oct. 20 & 0800 & 1287 & 1288 \\
\hline & & & & & 1600 & 1288 & 1290 \\
\hline \multicolumn{3}{|c|}{$\begin{array}{l}\text { Reran instrument to } 5160 \mathrm{ft} \text { GL. } \\
\text { bottom at } 1600 \text {, Oct. } 7 \text {. }\end{array}$} & On & \multirow{2}{*}{\multicolumn{3}{|c|}{$\begin{array}{l}\text { Reran instrument to } 5160 \mathrm{ft} \mathrm{GL} \text {. } \\
\text { bottom at } 1700 \text {, Oct. } 21 .\end{array}$}} & On \\
\hline Oct. 7 & 2400 & 1265 & 1278 & & & & \\
\hline \multirow[t]{3}{*}{ Oct. 8} & 0800 & 1265 & 1278 & Oct. 21 & 2400 & 1290 & 1292 \\
\hline & 1600 & 1265 & 1278 & Oct. 22 & 0800 & 1290 & 1292 \\
\hline & 2400 & 1265 & 1278 & & 1600 & 1290 & 1293 \\
\hline \multirow[t]{3}{*}{ Oct. 9} & 0800 & 1267 & 1278 & & 2400 & 1292 & 1293 \\
\hline & 1600 & 1267 & 1279 & Oct. 23 & 0800 & 1292 & 1295 \\
\hline & 2400 & 1267 & 1279 & & 1600 & 1292 & 1295 \\
\hline \multirow[t]{3}{*}{ Oct. 10} & 0800 & 1267 & 1279 & & 2400 & 1292 & 1295 \\
\hline & 1600 & 1267 & 1279 & Oct. 24 & 0800 & 1292 & 1295 \\
\hline & 2400 & 1267 & 1279 & & 1600 & 1292 & 1295 \\
\hline \multirow[t]{3}{*}{ Oct. 11} & 0800 & 1268 & 1279 & & 2400 & 1292 & 1296 \\
\hline & 1600 & 1268 & 1279 & Oct. 25 & 0800 & 1293 & 1296 \\
\hline & 2400 & 1268 & 1279 & & 1600 & 1293 & 1296 \\
\hline \multirow[t]{3}{*}{ Oct. 12} & 0800 & 1268 & 1279 & & 2400 & 1295 & 1296 \\
\hline & 1600 & 1268 & 1281 & Oct. 26 & 0800 & 1295 & 1298 \\
\hline & 2400 & 1270 & 1281 & & 1600 & 1295 & 1298 \\
\hline \multirow[t]{2}{*}{ Oct. 13} & 0800 & 1270 & 1281 & & 2400 & 1295 & 1299 \\
\hline & & & & Oct. 27 & 0800 & 1295 & 1299 \\
\hline \multirow{2}{*}{\multicolumn{3}{|c|}{$\begin{array}{l}\text { Reran instrument to } 5160 \mathrm{ft} \mathrm{GL} \text {. } \\
\text { bottom on } 1300 \text {, Oct. } 14 .\end{array}$}} & On & & 1600 & 1295 & 1299 \\
\hline & & & & \multicolumn{4}{|c|}{ Reran instrument to $5160 \mathrm{ft} \mathrm{GL}$ at 1400 , } \\
\hline Oct. 14 & $\begin{array}{l}1600 \\
2400\end{array}$ & $\begin{array}{l}1281 \\
1281\end{array}$ & $\begin{array}{l}1284 \\
1284\end{array}$ & \multicolumn{4}{|c|}{$\begin{array}{l}\text { Oct. 28. Changed from Mountain Day- } \\
\text { light Time to Mountain Standard Time }\end{array}$} \\
\hline \multirow[t]{3}{*}{ Oct. 15} & 0800 & 1281 & 1284 & \multicolumn{4}{|c|}{ at this point. } \\
\hline & 1600 & 1282 & 1284 & & & & \\
\hline & 2400 & 1282 & 1285 & \multirow[t]{2}{*}{ Oct. 28} & 1600 & 1298 & 1301 \\
\hline \multirow[t]{4}{*}{ Oct. 16} & 0800 & 1284 & 1285 & & 2400 & 1298 & 1302 \\
\hline & 1600 & 1284 & 1285 & \multirow[t]{3}{*}{ Oct. 29} & 0800 & 1298 & 1302 \\
\hline & 2400 & 1284 & 1285 & & 1600 & 1299 & 1302 \\
\hline & & & & & 2400 & 1299 & 1302 \\
\hline
\end{tabular}




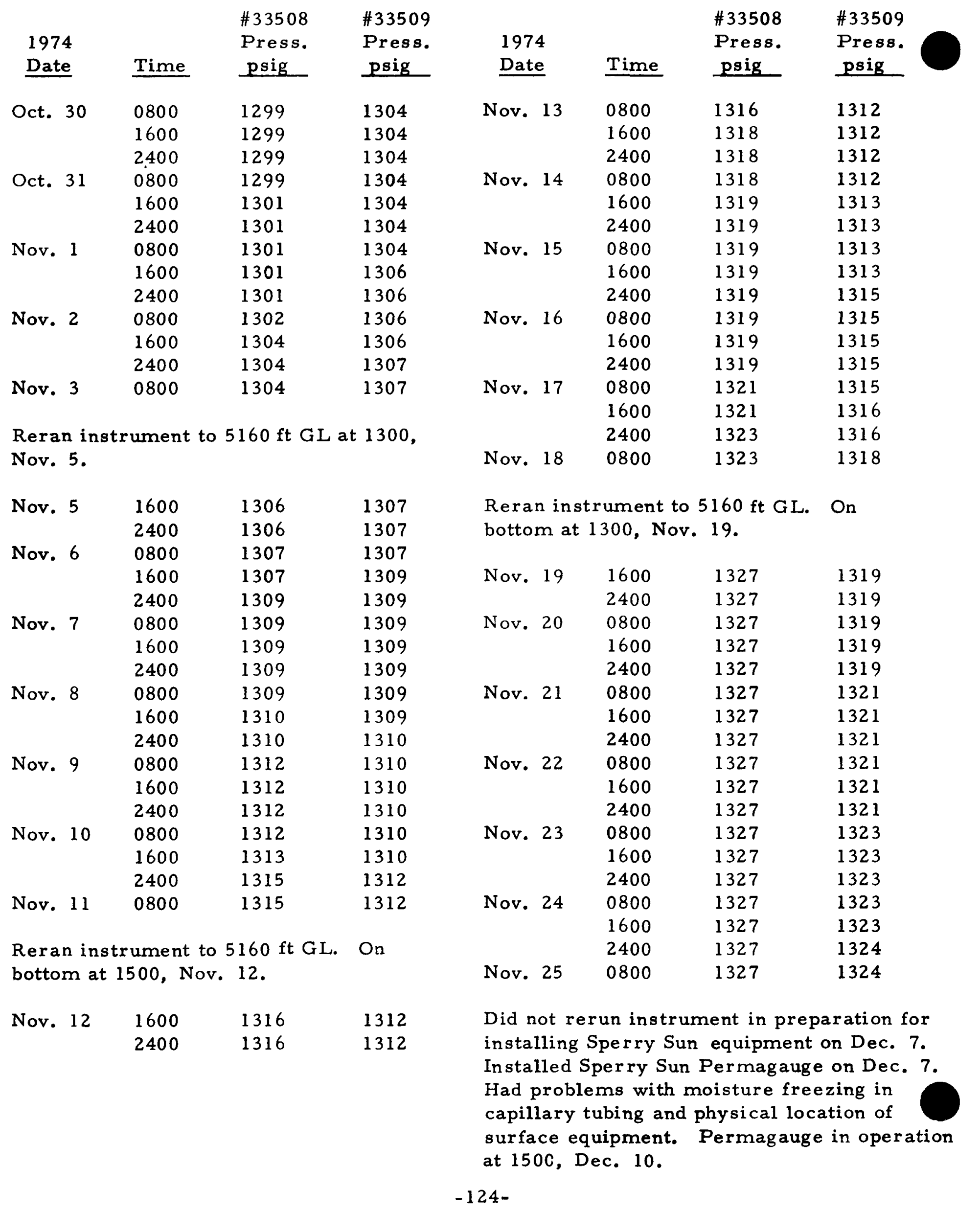




\begin{tabular}{|c|c|c|c|c|c|}
\hline $\begin{array}{l}1974 \\
\text { Date }\end{array}$ & Time & $\begin{array}{l}\text { BHP } \\
\text { psig }\end{array}$ & $\begin{array}{l}1975 \\
\text { Date } \\
\end{array}$ & Time & $\begin{array}{l}\text { BHP } \\
\text { pgig }\end{array}$ \\
\hline Dec. 10 & 1600 & 1335.7 & Jan. 21 & 1600 & 1368.4 \\
\hline Dec. 11 & 0800 & 1336.7 & & 2400 & 1368.2 \\
\hline Dec. 12 & 0800 & 1336.9 & Jan. 22 & 0800 & 1368.5 \\
\hline Dec. 13 & 0800 & 1337.8 & & 1600 & 1368.7 \\
\hline Dec. 14 & 0800 & 1340.8 & & 2400 & 1369.0 \\
\hline Dec. 15 & 0800 & 1342.0 & Jan. 23 & 0800 & 1369.1 \\
\hline Dec. 16 & 0800 & 1342.2 & & 1600 & 1369.6 \\
\hline Dec. 17 & 0800 & 1343.1 & & 2400 & 1369.2 \\
\hline Dec. 18 & 0800 & 1345.2 & Jan. 24 & $\begin{array}{l}0800 \\
1600\end{array}$ & $\begin{array}{l}1369.6 \\
1369.8\end{array}$ \\
\hline \multicolumn{4}{|c|}{ No data for dates of Dec. 19 to } & 2400 & 1370.0 \\
\hline \multicolumn{3}{|c|}{ Dec. 26.} & Jan. 25 & $\begin{array}{l}0800 \\
1600\end{array}$ & $\begin{array}{l}1370.2 \\
1370.2\end{array}$ \\
\hline Dec. 27 & 0800 & 1352.7 & & 2400 & 1370.8 \\
\hline Dec. 28 & 0800 & 1351.4 & Jan. 26 & 0800 & 1370.8 \\
\hline Dec. 29 & 0800 & 1352.2 & & 1600 & 1371.1 \\
\hline \multirow[t]{2}{*}{ Dec. 30} & 0800 & 1352.8 & & 2400 & 1371.2 \\
\hline & & & Jan. 27 & 0800 & 1371.3 \\
\hline \multirow{2}{*}{\multicolumn{4}{|c|}{ Lost power, reset at 1030, Dec. 31 . }} & 1600 & 1371.6 \\
\hline & & & & 2400 & 1371.7 \\
\hline \multirow[t]{2}{*}{ Dec. 31} & 1200 & 1351.7 & Jan. 28 & 0800 & 1372.0 \\
\hline & & & & 1600 & 1372.1 \\
\hline \multirow[t]{2}{*}{$\underline{1975}$} & & & & 2400 & 1372.2 \\
\hline & & & Jan. 29 & 0800 & 11372.4 \\
\hline Jan. 1 & 0800 & 1351.2 & & 1600 & 1372.8 \\
\hline Jan. 2 & 0800 & 1352.4 & & 2400 & 1372.9 \\
\hline Jan. 3 & 0800 & 1353.0 & Jan. 30 & 0800 & 1373.0 \\
\hline Jan. 4 & 0800 & 1368.7 & & 1600 & 1373.2 \\
\hline \multirow[t]{2}{*}{ Jan. 5} & 0800 & 1373.1 & & 2400 & 1373.8 \\
\hline & & & Jan. 31 & 0800 & 1373.5 \\
\hline \multicolumn{3}{|c|}{ Machine disconnected for move to } & & 1600 & 1373.6 \\
\hline \multicolumn{3}{|c|}{ different location on surface. No } & & 2400 & 1373.8 \\
\hline \multicolumn{3}{|c|}{ data for period Jan. 6 to Jan. 20 . } & Feb. 1 & 0800 & 1373.8 \\
\hline \multicolumn{3}{|c|}{ Arrived location at 1200, Jan. 21 . } & & 1600 & 1374.1 \\
\hline \multicolumn{3}{|c|}{ Changed routing of capillary tubing } & & 2400 & 1374.5 \\
\hline \multicolumn{3}{|c|}{ on surface so it would reach to new } & Feb. 2 & 0800 & 1374.2 \\
\hline \multicolumn{3}{|c|}{ location of Sperry Sun Permagauge. } & & 1600 & 1375.0 \\
\hline \multicolumn{3}{|c|}{ Hooked line in to Permagauge and } & & 2400 & 1375.1 \\
\hline \multirow{2}{*}{\multicolumn{3}{|c|}{$\begin{array}{l}\text { checked for leaks. Purged system } \\
\text { with } 50 \mathrm{ft}^{3} \text { of helium and let }\end{array}$}} & Feb. 3 & 0800 & 1375.3 \\
\hline & & & & 1600 & 1377.0 \\
\hline \multicolumn{3}{|c|}{ Permagauge reach equilibrium. } & & 2400 & 1377.2 \\
\hline \multicolumn{3}{|c|}{ Entered correction factor $s$ and } & Feb. 4 & 0800 & 1377.5 \\
\hline reset $\mathrm{ma}$ & & & & 1600 & 1377.5 \\
\hline & & & & 2400 & 1377.8 \\
\hline
\end{tabular}




\begin{tabular}{|c|c|c|c|c|c|}
\hline $\begin{array}{l}1975 \\
\text { Date }\end{array}$ & Time & $\begin{array}{l}\text { BHP } \\
\text { psig }\end{array}$ & $\begin{array}{l}1975 \\
\text { Date } \\
\end{array}$ & Time & $\begin{array}{l}\text { BHP } \\
\text { psig }\end{array}$ \\
\hline \multirow[t]{3}{*}{ Feb. 5} & 0800 & 1378.3 & \multirow{2}{*}{\multicolumn{3}{|c|}{$\begin{array}{l}\text { On May } 16 \text {, recorder was moved to } \\
\text { controlled environment. System }\end{array}$}} \\
\hline & 1600 & 1378.3 & & & \\
\hline & 2400 & 1378.5 & \multicolumn{3}{|c|}{ purged with helium. } \\
\hline \multirow[t]{3}{*}{ Feb. 6} & 0800 & 1378.8 & & & \\
\hline & 1600 & 1379.4 & \multirow[t]{2}{*}{ May 16} & 1600 & 1430.6 \\
\hline & 2400 & 1379.6 & & 2400 & 1430.6 \\
\hline \multirow[t]{3}{*}{ Feb. 7} & 0800 & 1379.8 & \multirow[t]{3}{*}{ May 17} & 0800 & 1430.8 \\
\hline & 1600 & 1379.8 & & 1600 & 1430.9 \\
\hline & 2400 & 1380.1 & & 2400 & 1427.9 \\
\hline \multirow[t]{3}{*}{ Feb. 8} & 0800 & 1380.4 & \multirow[t]{3}{*}{ May 18} & 0800 & 1428.1 \\
\hline & 1600 & 1380.4 & & 1600 & 1428.1 \\
\hline & 2400 & 1380.6 & & 2400 & 1428.3 \\
\hline \multirow[t]{3}{*}{ Feb. 9} & 0800 & 1380.8 & \multirow[t]{3}{*}{ May 19} & 0800 & 1428.5 \\
\hline & 1600 & 1381.1 & & 1600 & 1429.0 \\
\hline & 2400 & 1381.1 & & 2400 & 1428.9 \\
\hline \multirow[t]{3}{*}{ Feb. 10} & 0800 & 1381.5 & \multirow[t]{3}{*}{ May 20} & 0800 & 1429.0 \\
\hline & 1600 & 1381.6 & & 1600 & 1429.4 \\
\hline & 2400 & 1381.7 & & 2400 & 1429.3 \\
\hline \multirow[t]{3}{*}{ Feb. 11} & 0800 & 1381.9 & \multirow[t]{3}{*}{ May 21} & 0800 & 1429.6 \\
\hline & 1600 & 1382.3 & & 1600 & 1429.8 \\
\hline & 2400 & 1382.1 & & 2400 & 1429.9 \\
\hline \multirow[t]{3}{*}{ Feb. 12} & 0800 & 1382.4 & \multirow[t]{3}{*}{ May 22} & 0800 & 1430.2 \\
\hline & 1600 & 1382.9 & & 1600 & 1430.0 \\
\hline & 2400 & 1383.1 & & 2400 & 1430.0 \\
\hline \multirow[t]{3}{*}{ Feb. 13} & 0800 & 1383.3 & \multirow[t]{3}{*}{ May 23} & 0800 & 1430.8 \\
\hline & 1600 & 1383.2 & & 1600 & 1430.7 \\
\hline & 2400 & 1383.6 & & 2400 & 1430.3 \\
\hline \multirow[t]{3}{*}{ Feb. 14} & 0800 & 1383.6 & \multirow[t]{3}{*}{ May 24} & 0800 & 1430.7 \\
\hline & 1600 & 1383.9 & & 1600 & 1430.8 \\
\hline & 2400 & 1384.2 & & 2400 & 1430.8 \\
\hline Feb. 15 & 0800 & 1384.2 & May 25 & 0800 & 1430.8 \\
\hline & 1600 & 1384.5 & & 1600 & 1431.0 \\
\hline & 2400 & 1384.9 & & 2400 & 1431.1 \\
\hline Feb. 16 & 0800 & 1385.1 & May 26 & 0800 & 1432.1 \\
\hline & 1600 & 1385.2 & & 1600 & 1431.7 \\
\hline & 2400 & 1385.4 & & 2400 & 1431.4 \\
\hline & & & May 27 & 0800 & 1432.2 \\
\hline Data om & or Feb & : Feb. 26 & & 1600 & 1432.0 \\
\hline and for 1 & 31 to $N$ & Data & & 2400 & 1432.5 \\
\hline were unr & le beca & f temper - & May 28 & 0800 & 1432.8 \\
\hline ature eff & n Sper & In equip- & & 1600 & 1432.8 \\
\hline ment. I & ipmen & available & & 2400 & 1433.1 \\
\hline
\end{tabular}




\begin{tabular}{|c|c|c|c|c|c|}
\hline $\begin{array}{l}1975 \\
\text { Date }\end{array}$ & Time & $\begin{array}{l}\text { BHP } \\
\text { psig }\end{array}$ & $\begin{array}{l}1975 \\
\text { Date }\end{array}$ & Time & $\begin{array}{l}\text { BHP } \\
\text { psig }\end{array}$ \\
\hline \multirow[t]{3}{*}{ May 29} & 0800 & 1433.4 & June 12 & 0800 & 1436.3 \\
\hline & 1600 & 1433.1 & & 1600 & 1437.0 \\
\hline & 2400 & 1433.2 & & 2400 & 1435.9 \\
\hline \multirow[t]{3}{*}{ May 30} & 0800 & 1433.9 & June 13 & 0800 & 1436.0 \\
\hline & 1600 & 1433.8 & & 1600 & 1437.1 \\
\hline & 2400 & 1433.4 & & 2400 & 1436.8 \\
\hline \multirow{3}{*}{ May 31} & 0800 & 1433.8 & June 14 & 0800 & 1436.5 \\
\hline & 1600 & 1433.8 & & 1600 & 1437.6 \\
\hline & 2400 & 1433.9 & & 2400 & 1437.5 \\
\hline \multirow[t]{3}{*}{ June 1} & 0800 & 1434.1 & June 15 & 0800 & 1436.8 \\
\hline & 1600 & 1434.3 & & 1600 & 1438.4 \\
\hline & 2400 & 1434.3 & & 2400 & 1438.1 \\
\hline \multirow[t]{3}{*}{ June 2} & 0800 & 1434.5 & June 16 & 0800 & 1437.6 \\
\hline & 1600 & 1434.9 & & 1600 & 1438.6 \\
\hline & 2400 & 1434.7 & & 2400 & 1438.1 \\
\hline \multirow[t]{3}{*}{ June 3} & 0800 & 1434.6 & June 17 & 0800 & 1438.0 \\
\hline & 1600 & 1435.0 & & 1600 & 1438.6 \\
\hline & 2400 & 1435.0 & & 2400 & 1438.8 \\
\hline \multirow{3}{*}{ June 4} & 0800 & 1434.8 & June 18 & 0800 & 1438.5 \\
\hline & 1600 & 1435.5 & & 1600 & 1438.5 \\
\hline & 2400 & 1435.2 & & 2400 & 1438.0 \\
\hline \multirow[t]{3}{*}{ June 5} & 0800 & 1435.4 & June 19 & 0800 & 1438.0 \\
\hline & 1600 & 1435.9 & & 1600 & 1438.8 \\
\hline & 2400 & 1435.8 & & 2400 & 1438.7 \\
\hline \multirow[t]{3}{*}{ June 6} & 0800 & 1436.1 & June 20 & 0800 & 1438.6 \\
\hline & 1600 & 1436.4 & & 1600 & 1438.5 \\
\hline & 2400 & 1436.5 & & 2400 & 1438.8 \\
\hline \multirow[t]{3}{*}{ June 7} & 0800 & 1436.2 & June 21 & 0800 & 1439.1 \\
\hline & 1600 & 1436.1 & & 1600 & 1439.3 \\
\hline & 2400 & 1435.6 & & 2400 & 1439.1 \\
\hline \multirow[t]{3}{*}{ June 8} & 0800 & 1435.5 & June 22 & 0800 & 1439.2 \\
\hline & 1600 & 1435.4 & & 1600 & 1439.8 \\
\hline & 2400 & 1435.7 & & 2400 & 1439.7 \\
\hline \multirow[t]{3}{*}{ June 9} & 0800 & 1435.9 & June 23 & 0800 & 1439.6 \\
\hline & 1600 & 1436.0 & & 1600 & 1440.6 \\
\hline & 2400 & 1436.0 & & 2400 & 1440.5 \\
\hline \multirow[t]{3}{*}{ June 10} & 0800 & 1436.3 & June 24 & 0800 & 1440.2 \\
\hline & 1600 & 1436.1 & & & \\
\hline & 2400 & 1436.1 & \multirow{4}{*}{\multicolumn{3}{|c|}{$\begin{array}{l}\text { Terminated long term pressure build - } \\
\text { up monitoring on June } 24 \text {. }\end{array}$}} \\
\hline \multirow[t]{3}{*}{ June 11} & 0800 & 1436.3 & & & \\
\hline & 1600 & 1436.6 & & & \\
\hline & 2400 & 1436.4 & & & \\
\hline
\end{tabular}


-

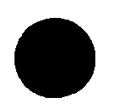

$-128-$ 


\section{APPENDIX E \\ SUMMARIES FROM RELEV ANT \\ RADIOLOGICAL MONITORING PROGRAM REPORTS}

(From Reference 8, PNE-RB-51-7 to - 10 inclusive) 
0

○

$-130-$ 


\section{SUMMARY OF RESULTS FOR NOVEMBER 1, 1973 THROUGH FEBRUARY 4, 1974}

Beta radioactivity in air particulate samples for this period remained at - very low concentrations, ranging from 0.02 to $0.13 \mathrm{pCi} / \mathrm{m}^{3}$. These values are consistent with values observed by Eberline at other sites during this period, at Rio Blanco during previous periods, and with values reported by the Environmental Protection Agency (EPA) Air Surveillance Network. Gamma scans of the air particulate samples (composite) indicated that the concentrations of gamma emitters we re below the minimum detectability of the 4-inch diameter $\times 4$-inch thick $\mathrm{NaI}(\mathrm{T} 1)$ detector.

TLD data for this period indicated an average background radiation dose rate of 2.25 millirem per week. This is consistent with the dose rate measured during the previous winter. Lower dose rates during the winter are attributable to attenuation of radiation from terrestrial sources due to snow cover.

Soil samples collected in November 1973 were analyzed for isotopes of plutonium, uranium and thorium. The concentration of plutonium was within the range of expected values due to worldwide fallout. The concentrations of uranium and thorium were within ranges that occur naturally.

Tritium concentrations in water measured by electrolytic enrichment were in the range of $<0.1 \mathrm{pCi} / \mathrm{ml}$ to $0.4 \mathrm{pCi} / \mathrm{ml}$. Other beta activity was in the range of 0.0 to $10.8 \mathrm{pCi} / 1$. 


\section{SUMMARY OF RESULTS FOR FEBRUARY 4, 1974 THROUGH APRIL 30, 1974}

Beta radioactivity in air particulate samples increased in March and April to a peak of $0.47 \mathrm{pCi} / \mathrm{m}^{3}$ from a mid-winter low of $0.02 \mathrm{pCi} / \mathrm{m}^{3}$. A seasonal increase is always noted in the spring, but this increase is more than usual and is attributable to injection of year-old fission products from the upper atmosphere inventory due to spring mixing of the upper and lower atmosphere. The presence of a fission product mixture consistent with the time delay since the June 26, 1973 test by the People's Republic of China indicates that this test is responsible for most of the increase in the spring of 1974. The increase is not attributable to Rio Blanco because it was typical of levels measured throughout the United States by Eberline and by the Environmental Protection Agency. For example, gamma isotopic analysis of composite filters from the southeastern United States showed the presence of the same approximately year-old fission product mixture at similar concentrations as measured at Rio Blanco.

Vegetation samples (Goldenrod, Sagebrush, Willow, Greasewood and Milk Cow Feed) were collected on March 29, 1974. Sr-89, tritium, and gamma emitters (other than natural $\mathrm{K}-40$ ) were not detected in any of the samples. The concentration of $\mathrm{Sr}-90$ ranged from 0.04 to $0.18 \mathrm{pCi} / \mathrm{g}$ (dry weight) and is attributable to worldwide fallout.

TLD data for this period indicated an average background dose rate of 3.0 mrem/week. This is higher than the dose rate measured during the winter $(2.25 \mathrm{mrem} /$ week) and is attributable to increased dose rate from terrestrial sources due to the melting of the winter snow cover or to the increased worldwide fallout during this period.

Water samples collected during March 1974 did not indicate the presence of any unexpected radioactivity. Gross beta concentrations ranged up to a maximum of $8 \pm 4 \mathrm{pCi} / 1$. Tritium was measured in some of the samples by electrolytic enrichment. Concentrations of tritium ranged from $0.12 \pm 0.08$ to $0.25 \pm$ $0.08 \mathrm{pCi} / \mathrm{ml}$.

Gamma emitters, other than natural radioactivity were not detected in samples collected on March 29, 1974.

Cesium-137 was measured in soil samples collected on March 29, 1974 with concentrations ranging from less than 0.09 to $0.9 \mathrm{pCi} / \mathrm{g}$ (dry weight). Tritium and gamma emitters (except natural radioactivity) were not detected in any of the samples. 
Beta radioactivity in air particulate samples continued to increase into May 1974 as noted during the previous period, peaking during the first two weeks of May 1974. This increase is attributable, as in the previous period, to injection of year-old fission products from the upper atmosphere due to spring mixing of the upper and lower atmosphere. The increase in radioactivity is not attributable to Project Rio Blanco. After the second week in May, the air concentration shows a decreasing trend froma peak concentration of 0.54 $\mathrm{pCi} / \mathrm{m}^{3}$ in May to less than $0.1 \mathrm{pCi} / \mathrm{m}^{3}$ at the end of July.

TLD data for this period indicated an average background dose rate of 2.2 $\mathrm{mrem} /$ week. There is no evidence of any increase due to Rio Blanco.

Water samples collected during. July 1974 did not indicate the presence of any unexpected radioactivity. Gross beta concentration, other than tritium, were below $10 \mathrm{pCi} / 1$. Tritium was measured in four samples by electrolytic enrichment followed by liquid scintillation counting. Concentrations of tritium ranged from $0.14 \pm 0.08$ to $0.49 \pm 0.08 \mathrm{pCi} / \mathrm{ml}$. This tritium is attributable to natural production in the atmosphere and worldwide fallout from weapons testing. This concentration is a small fraction of the peak in 1963 caused by weapons testing in the atmosphere. Gamma emitters were not detected by gamma spectrometry in any of the samples.

Gamma emitters other than natural $\mathrm{K}-40$ were not detected in three milk samples collected in July 1974. 


\section{REFERENCES}

1. Project Rio Blanco, Final Report, Detonation Related Activities, CER Geonuclear Corporation/Continental Oil Company, June 30, 1975, PNE-RB-67.

2. Project Rio Blanco Definition Plan, CER Geonuclear Corporation, January 24, 1973, PNE-RB-16.

3. Rio Blanco Massive Hydraulic Fracture Project Definition, CER Geonuclear Corporation, 1974, otherwise undated.

4. Katz, D. L., et al, Handbook of Natural Gas Engineering, McGraw-Hill Book Company, New York, 1959, p. 196.

5. Status of Water Disposal Well (Fawn Creek Government No. 1) Project Rio Blanco, a report to the Colorado Department of Health, June 20, 1974, CER Geonuclear Corporation.

6. Project Rio Blanco, Radioactivity and the Environment, PNE-RB-63, CER Geonuclear Corporation, March 3, 1975.

7. Project Rio Blanco Data Report, Production Testing (RB-E-01), November 1973 and January-February 1974, NVO-148 (PNE-RB-61), Nevada Operations Office, U.S. Atomic Energy Commission, September 1974.

8. Radiological Monitoring Program, Project Rio Blanco, reported to CER Geonuclear Corporation by the Eberline Instrument Corporation, PNE-RB-51-1 to 10 , inclusive.

9. Environmental Statement, Rio Blanco Gas Stimulation Project, WASH-1519, U.S. Atomic Energy Commission, April 1972, with addendum March 1973. 